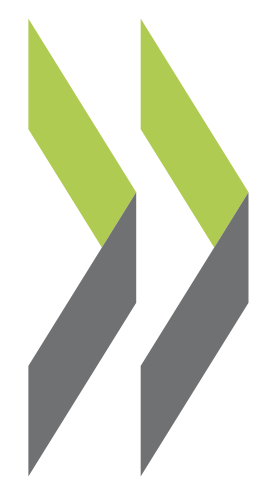

OECD Economics Department Working Papers No. 347

Regulation, Productivity and Growth: OECD

Evidence

Giuseppe Nicoletti, Stefano Scarpetta 
Organisation de Coopération et de Développement Economiques

Organisation for Economic Co-operation and Development

13-Jan-2003

ECONOMICS DEPARTMENT

English text only

REGULATION, PRODUCTIVITY AND GROWTH: OECD EVIDENCE

ECONOMICS DEPARTMENT WORKING PAPERS NO. 347

by

Giuseppe Nicoletti and Stefano Scarpetta

All Economics Department Working Papers are now available through OECD's Internet Web site at http:/www.oecd.org/eco 


\section{ABSTRACT/ RÉSUMÉ}

\section{REGULATION, PRODUCTIVITY AND GROWTH: OECD EVIDENCE}

In this paper, we relate the scope and depth of regulatory reforms to growth outcomes in OECD countries. By means of a new set of quantitative indicators of regulation, we show that the cross-country variation of regulatory settings has increased in recent years, despite extensive liberalisation and privatisation in the OECD area. We then look at the regulation-growth linkage using data that cover a large set of manufacturing and service industries over the past two decades. We focus on multifactor productivity (MFP), which plays a crucial role in GDP growth and accounts for a significant share of its cross-country variance. We find evidence that reforms promoting private governance and competition (where these are viable) tend to boost productivity. Both privatisation and entry liberalisation are estimated to have a positive impact on productivity. In manufacturing the gains are greater the further a given country is from the technology leader, suggesting that regulation limiting entry may hinder the adoption of existing technologies, possibly by reducing competitive pressures, technology spillovers, or the entry of new high-tech firms. These results offer an interpretation to the observed recent differences in growth patterns across OECD countries, in particular between large Continental European economies and the United States. Strict product market regulationsand lack of regulatory reforms-are likely to underlie the relatively poorer productivity performance of some European countries, especially in those industries where Europe has accumulated a technology gap (e.g. ICT-related industries).

JEL classification: O4, L5, K23, L33, L16, C23

Keywords: Growth, productivity, regulation, privatisation, models with panel data

\section{RÉGULATION, PRODUCTIVITÉ ET CROISSANCE DANS LES PAYS DE L'OCDE}

Cette étude essaye de mettre en relation les résultats de croissance dans les pays OCDE avec l'étendue et la profondité des réformes affectant le degré de concurrence sur les marchés des biens. A l'aide de nouveaux indicateurs quantitatifs de régulation, nous montrons qu'en dépit de la libéralisation des marchés et des privatisations d'entreprises publiques réalisées dans la zone OCDE, les différences dans les environnements réglementaires se sont récemment accrues. Nous utilisons ensuite des données qui couvrent de nombreuses industries de biens manufacturés et de services au cours des deux dernières décennies pour explorer le lien entre la régulation et la croissance. L'analyse se concentre sur la productivité globale des facteurs (MFP), qui joue un rôle central pour la croissance du PIB et explique une part importante de sa variabilité en coupe pays. Nous trouvons que les réformes encourageant la gouvernance privée des entreprises et la concurrence (là où les privatisations et les libéralisations des marchés sont désirables) tendent à avoir un effet positif sur la productivité. Dans le secteur manufacturier, les gains de productivité impliquués par ces politiques sont d'autant plus importants que la performance du pays concerné par les réformes est éloignée de celle du pays leader en technologie. Ainsi, la régulation anticoncurrentielle pourrait empêcher l'adoption des technologies existantes, en réduisant les pressions concurrentielles, les transferts de technologie, ou l'entrée de nouvelles entreprises dans les secteurs à haute technologie. Ces résultats pourraient expliquer les différences observées récemment dans les profils de croissance des pays de l'OCDE, particulièrement entre les grands pays de l'Europe continentale et les Etats Unis. Une régulation trop sévère des marchés des biens, ainsi que le manque d'en train dans le processus de réforme de la réglementation, sont probablement à la base des résultats de productivité relativement décevants obtenus dans plusieurs pays européens, surtout dans les industries où l'Europe a accumulé un retard technologique important (par exemple dans les industries qui produisent ou utilisent les technologies de l'information et de la communication).

Classification JEL: O4, L5, K23, L33, L16, C23

Mots-Clés: Croissance, productivité, régulation, privatisation, modèles avec données de panel

\section{Copyright OECD, 2003}

Applications for permissions to reproduce or translate all, or part of, this material should be made to: Head of Publications Services, OECD, 2 rue André Pascal, 75775 Paris Cedex 16, France. 


\section{TABLE OF CONTENTS}

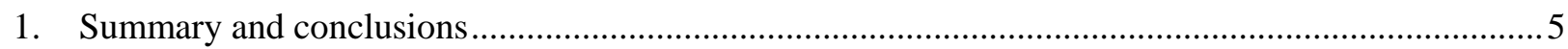

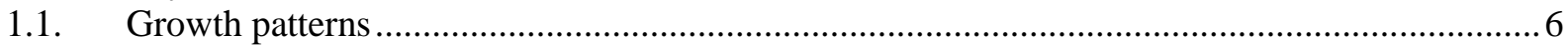

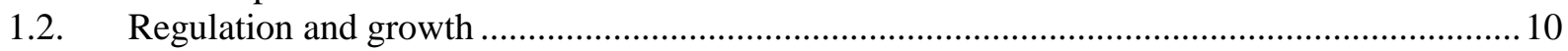

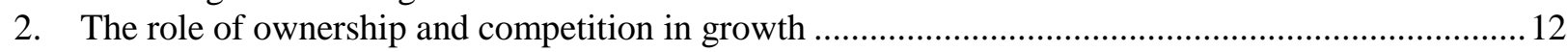

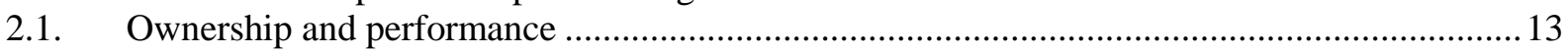

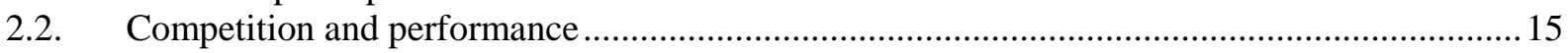

3. Product market regulation, governance and competition in OECD countries................................... 17

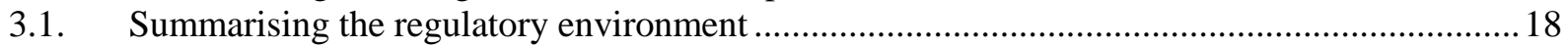

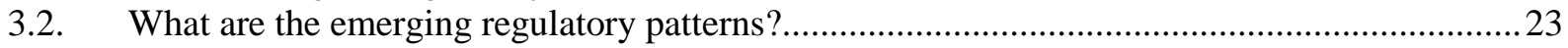

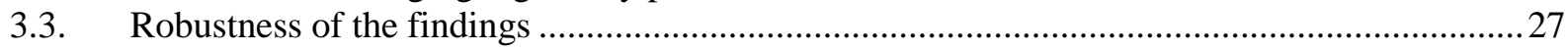

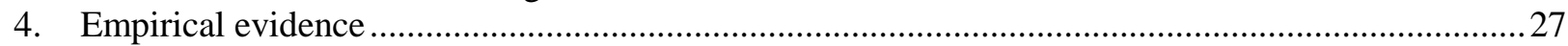

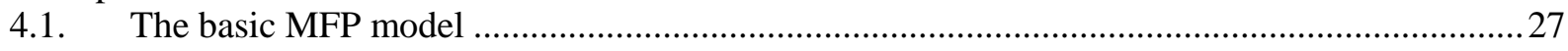

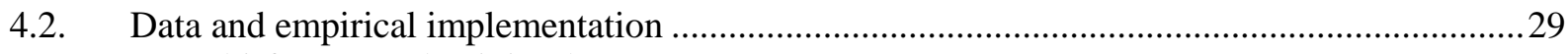

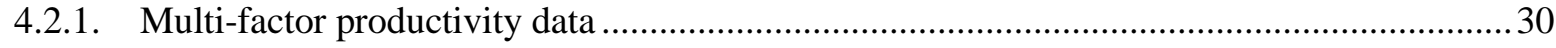

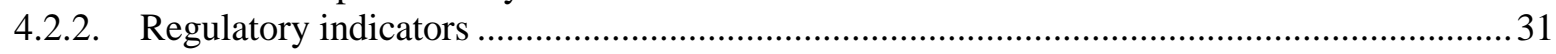

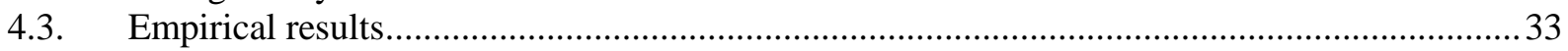

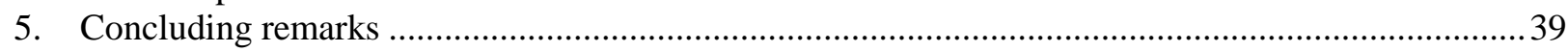

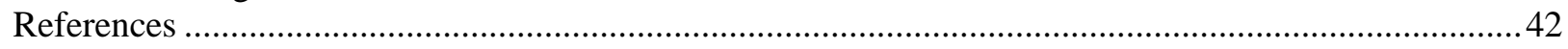

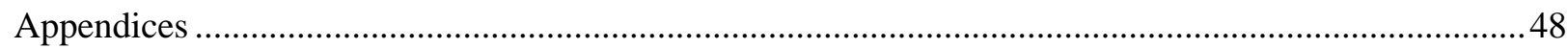

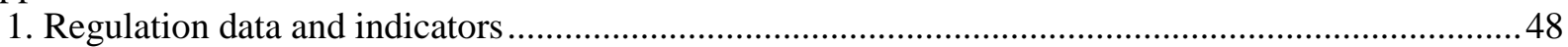

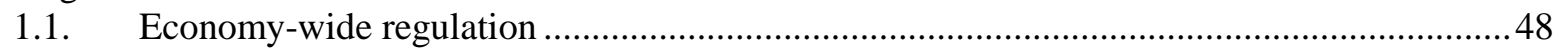

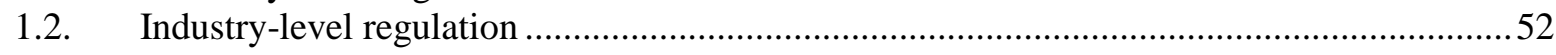

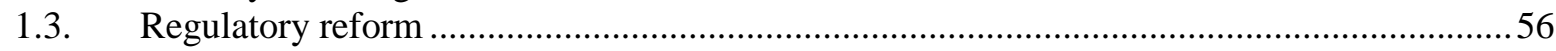

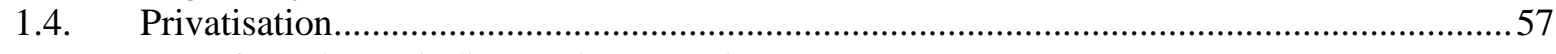

1.5. Use of regulatory indicators in regressions .................................................................58

2. The construction of MFP measures and sensitivity of results........................................................58

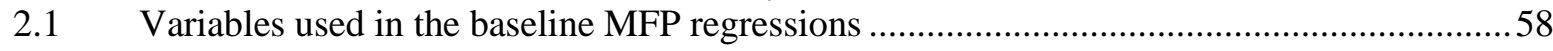

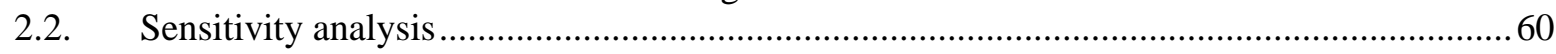

\section{Boxes}

Box 1. Using multi-factor productivity (MFP) growth as a proxy for technological progress ................. 8

Box 2. Differentiating anticompetitive regulations across industries...................................................2 


\section{Tables}

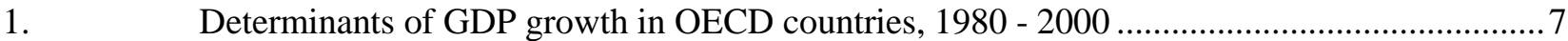

2. Decomposition of labour productivity growth across industries ...........................................

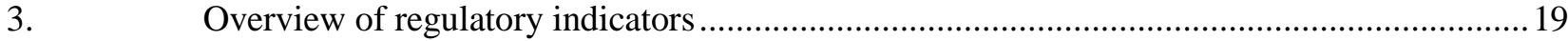

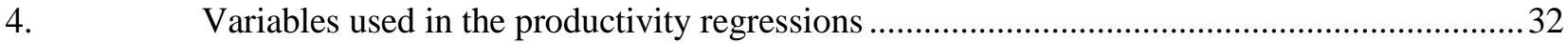

5. $\quad$ MFP regressions: selection of the baseline specification ................................................... 34

6. $\quad$ MFP regressions: The role of aggregate product market regulation and privatisation.............36

7. $\quad$ MFP regressions: The role of regulation in manufacturing and services ................................37

8. $\quad$ MFP regressions: The role of industry-specific regulations and regulatory reforms ...............38

\section{Figures}

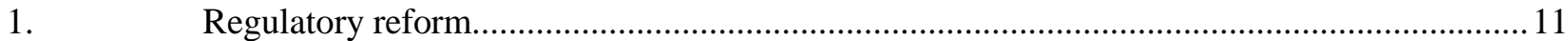

2. Multifactor productivity acceleration and product market regulation ..................................13

3. Privatisation and regulatory reform in OECD countries ..................................................24

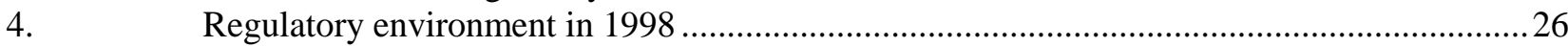

\section{Appendix Tables}

A.1. Indicator of administrative regulation: basic components and aggregation steps .................50

A.2. Subjective and objective measures of economy-wide product market regulation, late 1990s 51

A.3. Industry-level indicators: sources and sample coverage..................................................52

A.4. Industry-level indicators: coverage of regulatory areas......................................................53

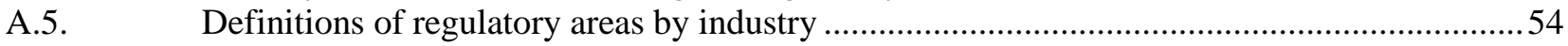

A.6. Technology leaders on the basis of relative MFP levels, 1984, $1997 \ldots \ldots \ldots \ldots \ldots \ldots \ldots \ldots \ldots \ldots \ldots \ldots \ldots . . .60$

A.7. Sensitivity of MFP regressions: preferred specifications without control for outliers ............61

\section{Appendix Figures}

A.1. A map of indicators of regulation.

A.2 Sensitivity analysis: T-statistics of estimated coefficients 
ECO/WKP(2003)1

\title{
REGULATION, PRODUCTIVITY AND GROWTH: OECD EVIDENCE
}

\author{
Giuseppe Nicoletti and Stefano Scarpetta ${ }^{1}$
}

\section{Summary and conclusions}

1. One of the most striking economic facts in the OECD area is the considerable dispersion of growth rates observed in the past decade, when some countries (most notably the United States) have pulled ahead in terms of output and productivity growth, while others (e.g. large Continental European economies) have lagged behind. This has reversed a long-standing process of convergence in living standards and productivity levels and is at odds with both underlying market forces that have led to increasing economic integration and a generalised move towards sound macroeconomic policy settings. What determined these marked differences in growth outcomes? It is natural to seek explanations where OECD economies are likely to differ most, namely their institutional environment and product and labour market policies affecting entrepreneurial choices. These factors may have played a particularly important role in the past decade when growth was associated with the spread of information and communication technology (ICT), and the latter has arguably been boosted by the entry of new, innovative firms in most markets as well as by technology adoption of incumbent firms.

2. While differences in labour market arrangements on the two sides of the ocean have often been emphasised, product market conditions are likely to have had a more direct bearing on growth. Product market institutions and policies affect in important ways firm governance structures, including public vs. private ownership, entrepreneurial incentives, and market access. In turn, good governance, strong incentives and competitive pressures are likely to encourage productivity improvements and innovation.

3. Institutions, policies and ownership structures have changed a lot over the past decades, as most OECD countries (as well as many non-OECD countries) implemented a wave of product market reforms aimed at making the regulatory environment friendlier to competition and reduce the role of public enterprises through large-scale privatisation. However, both initial conditions and the pace of reform have differed widely across countries, leading to persistent differences in the product market environment. Moreover, the effects of these reforms on economic outcomes are still a matter of controversy. Were they successful in increasing competitive pressures? Did privatisation actually affect governance? And, if so, did stronger competition and private ownership improve overall productivity outcomes? The empirical studies that explored the linkage between ownership structures, competition and productivity often focused on specific industries or panels of firms (e.g. D'Souza and Megginson, 1999; McKinsey, 1997; Nickell, 1996). While this allows controlling for the specific market conditions in which business decisions are taken, it precludes the analysis of the economy-wide growth implications because general equilibrium effects that depend on cross-sectoral linkages and adjustment potential of each economy are ignored (for example, OECD, 1997a, 1997b, highlights such linkages). Richard Baldwin and two anonymous referees for their valuable comments and Thierry Tressel for his significant contribution to the construction of the industry-level database and the econometric analysis of productivity. The views expressed in this paper are those of the authors and should not be held to represent those of the OECD or of its Member countries. 
4. Can changes in ownership structures and competitive pressures faced by firms at the national and industry levels help to explain differences in MFP growth outcomes? In this paper, we address this issue exploring the links between productivity performance and privatisation and regulatory reform policies. A distinctive feature of our analysis is that we do not attempt to measure directly the degree of entrepreneurial incentives and competition at the industry or nation-wide levels, a task fraught with conceptual and empirical shortcomings, but focus instead on their policy determinants: product market regulations that affect the ability of firms to enter markets (e.g. by creating fixed costs) or compete effectively with other firms (e.g. by distorting market mechanisms) and the degree of public ownership of business enterprises. We first describe these policy patterns by means of an original set of indicators of product market regulation and public ownership, checking whether convergence in policies has occurred in recent years. We show that, while on average the OECD area has become more market-friendly, the dispersion in regulatory settings has increased. We then investigate the impact of privatisation and liberalisation policies on growth focusing on multifactor productivity (MFP), which plays a crucial role in GDP growth and accounts for a high share of its cross-country variance. We then estimate the effects of these policies on the level of MFP and the speed of its convergence to best practice, defined as the highest level of MFP reached in each of the industries covered by the analysis. To this end, we use data covering a large set of manufacturing and service industries in several OECD countries over the past two decades.

5. In the rest of this section, we summarise the stylised facts to be explained and our major findings. In Section 2, we highlight the channels through which ownership structures and barriers to competition may affect MFP outcomes, drawing on the existing literature. In Section 3, we illustrate how barriers to competition and the degree of public ownership vary across countries and over time, explaining how we measure these patterns for empirical purposes. In Section 4, we describe our empirical approach and present our empirical results. Section 5 provides some concluding remarks.

\subsection{Growth patterns}

6. There has been a renewed interest in economic growth in recent years, largely motivated by a widespread perception of diverging growth patterns in OECD countries. A simple comparison of average (cyclically-adjusted) growth rates and their main determinants largely confirms this perception (Table 1). While GDP growth in the business sector ${ }^{2}$ has accelerated in the United States and Canada and a number of smaller countries, it has slowed down in Europe (defined as EU15) and Japan. The European growth patterns are largely the result of poor growth performance of the largest economies, while some (mainly small) countries have shown clear signs of acceleration in growth. The table also shows how these different growth patterns have come about. Labour productivity growth accounts for at least half of GDP growth in most OECD countries, providing a much larger contribution in many of them. Notwithstanding differences in labour productivity growth rates across countries, it is noticeable that the overall dispersion did not increase in the 1990s as compared with the 1980s, despite the significant widening in the variance of GDP growth rates. A key factor to reconcile growing disparities in GDP per capita growth rates in the context of broadly stable differences in labour productivity growth is the divergence in patterns of labour input (employment plus hours). Significant increases in labour input in Ireland, the Netherlands (in both cases, the decline in hours worked was more than compensated by the increase in employment), Spain and the United States contrast sharply with slumps in Japan, and in most large European countries.

2 In our analysis, we exclude community, personal and social services because of the poor quality of data. 
Table 1. Determinants of GDP growth in OECD countries, 1980 - 2000 Percentage change at annual rate, trend series ${ }^{\prime}$

Summary of business sector GDP growth and its components

\begin{tabular}{|c|c|c|c|c|c|c|c|c|c|c|c|c|c|c|c|}
\hline & \multicolumn{3}{|c|}{ GDP } & \multicolumn{3}{|c|}{ Total hours } & \multicolumn{3}{|c|}{ Labour productivity } & \multicolumn{3}{|c|}{ Capital deepening } & \multicolumn{3}{|c|}{ MFP } \\
\hline & $1980-199 \mathrm{C}$ & $90-200$ & $96-2000^{4}$ & $\mid 1980-1990$ & $90-200$ & $96-2000^{4}$ & 1980-199 & $90-200$ & 96-20004 & 1980-199 & $90-200$ & $996-2000^{7}$ & 1980-199C & $90-200$ & $96-2000^{7}$ \\
\hline United States & 3.3 & 3.6 & 4.1 & 2.0 & 2.2 & 2.5 & 1.3 & 1.4 & 1.6 & 2.9 & 2.5 & 3.0 & 0.9 & 1.1 & 1.3 \\
\hline Japan & 4.1 & 1.7 & 1.0 & 0.7 & -0.6 & -0.9 & 3.3 & 2.3 & 1.9 & 6.5 & 5.1 & 4.3 & 2.2 & 1.0 & 0.7 \\
\hline Germany & 2.3 & 1.8 & 2.1 & -0.2 & -0.1 & 0.5 & 2.5 & 1.9 & 1.6 & 3.7 & 3.2 & 3.0 & 1.5 & 0.9 & 0.8 \\
\hline France & 2.3 & 2.1 & 2.6 & -0.9 & 0.1 & 0.8 & 3.2 & 2.0 & 1.8 & 4.0 & 3.1 & 2.7 & 1.9 & 1.0 & 1.1 \\
\hline Italy & 2.5 & 1.9 & 2.1 & 0.1 & -0.1 & 0.5 & 2.4 & 2.0 & 1.6 & 3.2 & 3.0 & 3.0 & 1.5 & 1.0 & 0.7 \\
\hline United Kingdom & 3.1 & 2.0 & 2.6 & 0.7 & 0.7 & 1.2 & 2.3 & 1.4 & 1.5 & 2.8 & 2.8 & 2.8 & 1.0 & 0.7 & 1.0 \\
\hline Canada & 2.7 & 3.1 & 4.0 & 1.5 & 1.6 & 2.4 & 1.2 & 1.5 & 1.6 & 3.5 & 1.4 & 0.9 & 0.6 & 1.3 & 1.7 \\
\hline Australia & 3.5 & 4.1 & 4.5 & 2.1 & 2.0 & 2.2 & 1.4 & 2.1 & 2.2 & 4.4 & 4.1 & 4.5 & 0.6 & 1.3 & 1.4 \\
\hline Austria & 2.4 & 2.7 & 2.6 & 0.2 & 0.1 & 0.0 & 2.7 & 2.6 & 2.7 & 4.4 & 4.4 & 4.3 & 1.8 & 1.6 & 1.5 \\
\hline Belgium & 2.6 & 2.1 & 2.2 & 0.0 & -0.1 & 0.1 & 2.6 & 2.3 & 2.2 & 3.4 & 3.8 & 3.8 & 1.7 & 1.2 & 1.2 \\
\hline Denmark & 2.2 & 2.6 & 3.1 & 0.3 & 0.3 & 1.0 & 1.9 & 2.3 & 2.1 & 3.8 & 2.5 & 2.4 & 1.0 & 1.5 & 1.4 \\
\hline Finland & 2.6 & 2.9 & 4.9 & -1.0 & -0.7 & 1.5 & 3.7 & 3.7 & 3.3 & 3.2 & 0.8 & 0.7 & 2.4 & 3.2 & 3.6 \\
\hline Greece & 0.7 & 2.1 & 2.8 & 0.2 & 0.7 & 0.8 & 0.6 & 1.4 & 2.0 & 0.4 & 2.2 & 3.5 & 0.6 & 0.8 & 0.9 \\
\hline Ireland & 4.4 & 7.4 & 8.7 & 0.1 & 2.8 & 4.1 & 4.3 & 4.5 & 4.4 & 2.7 & 3.3 & & 3.6 & 4.4 & \\
\hline Netherlands & 2.2 & 3.1 & 3.4 & -1.1 & 0.9 & 1.7 & 3.3 & 2.1 & 1.6 & 3.6 & 3.4 & 3.5 & 2.3 & 1.6 & 1.2 \\
\hline New Zealand & 1.3 & 2.9 & 3.3 & -0.1 & 2.1 & 2.3 & 1.4 & 0.7 & 0.9 & 3.1 & 2.2 & 2.5 & 0.2 & 0.8 & 0.9 \\
\hline Norway & 1.4 & 2.5 & 2.9 & -0.5 & 0.2 & 1.0 & 1.9 & 2.2 & 1.8 & 2.7 & 2.1 & 2.9 & 1.2 & 1.7 & 1.3 \\
\hline Portugal & 3.7 & 2.1 & & 0.7 & -0.4 & & 3.0 & 2.5 & & & & & & & \\
\hline Spain & 2.4 & 2.9 & 3.5 & -1.0 & 1.1 & 2.4 & 3.5 & 1.8 & 1.1 & 4.4 & 4.2 & 3.9 & 2.1 & 0.7 & 0.5 \\
\hline Sweden & 2.1 & 2.4 & 3.4 & 0.5 & 0.2 & 1.5 & 1.6 & 2.2 & 1.9 & 2.0 & 1.5 &.. & 1.0 & 1.4 &.. \\
\hline Switzerland & 1.7 & 0.5 & 1 & 2 & 0.1 & 0.1 & $\ddot{7}$ & 0.3 & 39 &.. & 2.7 &.. &.. &.. &.. \\
\hline$\frac{\text { Korea }}{\text { Weighted average: }}$ & 9.2 & 6.1 & 4.1 & 2.0 & 1.0 & 0.3 & 1.0 & 5.0 & 0.0 & & & & & & \\
\hline & 2.5 & 2.2 & 2.6 & -0.2 & 0.3 & 0.9 & 2.7 & 1.9 & 1.6 & 3.4 & 3.1 & 2.9 & 1.5 & 1.0 & 0.9 \\
\hline $\begin{array}{l}\text { OECD } 24^{9} \\
\text { Standard deviation: }\end{array}$ & 3.1 & 2.7 & 3.0 & 0.9 & 1.0 & 1.3 & 2.1 & 1.7 & 1.7 & 3.7 & 3.1 & 3.1 & 1.3 & 1.1 & 1.1 \\
\hline EU15 $5^{8}$ & & & 1.77 & & 0.85 & 1.09 & 0.93 & 0.84 & 0.89 & 1.09 & 1.01 & 0.96 & 0.77 & 1.07 & 0.82 \\
\hline OECD24 ${ }^{9}$ & 0.91 & 1.31 & 1.59 & 0.92 & 0.99 & 1.15 & 0.99 & 0.89 & 0.79 & 1.21 & 1.08 & 1.06 & 0.81 & 0.90 & 0.68 \\
\hline
\end{tabular}

justment applies an extended version of the Hodrick-Prescott filter where the well-known end-of-sample problem is minimised by prolonging the time-series out of sample using OECD medium term projections. See Scarpetta et al. (2000) for a sensitivity analysis using different smoothing procedures.

2. 1983-1990 for Belgium, Denmark, Greece and Ireland, 1985-1990 for Austria and New Zealand, 1986-1990 for Portugal.

3. 1991-1996 for Switzerland, 1990-1997 for Austria, Belgium, New Zealand, 1990-1998 for Ireland, Korea and Netherlands, 1990-1999 for Denmark, Greece,Japan and United Kingdom

4. 1996-1997 for Austria, Belgium, New Zealand, 1996-1998 for Ireland, Korea and Netherlands, 1996-1999 for Denmark, Greece,Japan and United Kingdom.

5. 1983-1990 for Belgium, Denm ark, Greece and Ireland, 1985-1990 for Austria and New Zealand, 1987-1990 for United Kingdom.

6. 1991-1996 for Switzerland, 1990-1996 for Ireland and Sweden, 1990-1997 for Austria, Belgium, New Zealand and United Kingdom, 1990-1998 for Netherlands, 1990-1999 for Australia,

Denmark, France, Greece, ltaly and Japan.

U United Kingdom, 1996-1998 for Netherlands, 1996-1999 for Australia, Denmark, France, Greece, Italy and Japan.

9. Excluding Czech Republic, Hungary, Iceland, Korea, Luxembourg, Mexico, Poland, Slovak Republic and Turkey. 
7. The table also illustrates significant differences in the drivers of labour productivity. In most European countries, high (or even rising) growth rates of labour productivity have been achieved by a marked process of capital deepening. Given the poor employment performance, this was largely due to substitution of labour with capital rather than to strong investment in physical capital. In contrast, labour productivity has been driven by a combination of employment-friendly capital deepening and growth in MFP (a proxy for technical progress) in the United States, Australia, Ireland, Canada and Norway. These are the countries where most of the drivers of growth have improved, leading to acceleration in overall GDP growth. ${ }^{3}$

\section{Box 1. Using multi-factor productivity (MFP) growth as a proxy for technological progress}

Estimates of multifactor productivity (MFP) growth are often used to proxy technological progress. They are obtained as the residual output growth once the weighted contributions of changes in capital and labour inputs are accounted for. Therefore, MFP growth estimates involve a number of assumptions concerning the measurement of output and inputs.

First, given data limitation, we used total hours worked as the measure of labour input and the total capital stock as the measure of the capital input, i.e. no control was made for changes in the skill composition of the workforce of for changes in the composition of the capital stock. Arguably these MFP growth estimates reflect both disembodied and embodied components of technological progress. The disembodied component captures technological and organisational improvements that increase output for a given amount of -- quality and compositionally adjusted -inputs. However, we also wanted to assess the extent to which improvements in the quality of labour and capital boosted productivity in industries and countries that have invested in them. This second component of technological progress is termed embodied and proxies for the improvements in the productive capacity due to shifts to higher quality factor inputs. (see also Greenwood et al. 1997, Hercowitz, 1998).

Second, the weights of factor inputs in the calculation of the MFP growth residual should correspond to the marginal productivity of labour and capital. These are not observable and we followed the standard procedure of proxying them with income shares, which can be easily computed from national accounts. This corresponds to making a few assumptions, most importantly that the product and input markets are perfectly competitive and that there are constant returns to scale (Morrison, 1999). However, we recognise that elasticities can vary significantly for reasons other than measurement errors and use time varying factor shares. For a sensitivity analysis of the MFP estimates obtained with this approach and those obtained using elasticities estimated econometrically, see Scarpetta et al. (2000). Moreover, Scarpetta and Tressel (2002a) present a sensitivity analysis in which the industry-level productivity regressions use MFP estimates that control for quality changes in the labour input and for the presence of price mark-ups over marginal costs.

8. Productivity growth has also differed significantly across industries within each country, with particular industries showing spectacular performance (Table 2). While contributions to growth over the 1990s vary across manufacturing and service industries in almost all OECD countries, the patterns are very different on the two sides of the ocean. In the United States, productivity growth has been primarily driven by high-tech manufacturing industries and service industries with a low skill content (e.g. retail trade and hotels and restaurants). In Europe (and Japan) the drivers of aggregate manufacturing productivity growth were industries with low or medium level technologies, while productivity growth in the service industry was largely driven by relatively high-skills industries (e.g. telecommunications and finance). Given the

3 From these findings, it emerges that labour productivity growth may be a misleading proxy for efficiency enhancement, especially in countries where it was sustained by skill biased employment patterns. 
Table2 Decomposition of labour productivity growth across industries

Average annual percentage changes

\begin{tabular}{|c|c|c|c|c|c|c|c|c|c|c|c|c|c|c|c|c|c|c|}
\hline & \multicolumn{2}{|c|}{ Australia } & \multicolumn{2}{|c|}{ Canada } & \multicolumn{2}{|c|}{ Finland } & \multicolumn{2}{|c|}{ France } & \multicolumn{2}{|c|}{ Italy } & \multicolumn{2}{|c|}{ Japan } & \multicolumn{2}{|c|}{ Netherlands } & \multicolumn{2}{|c|}{ United States } & \multicolumn{2}{|c|}{ West Germany } \\
\hline & Value & $\%$ & Value & $\%$ & Value & $\%$ & Value & $\%$ & Value & $\%$ & Value & $\%$ & Value & $\%$ & Value & $\%$ & Value & $\%$ \\
\hline Mning and quamying & 0.20 & 10.0 & 0.27 & 16.8 & 0.01 & 0.3 & 0.04 & 24 & - & - & 0.00 & 0.0 & 0.11 & 9.8 & 0.07 & 3.6 & 0.04 & 20 \\
\hline High-technology menufactures & 0.03 & 1.5 & 0.09 & 5.5 & 0.30 & 7.0 & 0.17 & 10.1 & 0.03 & 1.2 & 0.37 & 29.3 & 0.18 & 16.4 & 0.36 & 19.5 & 0.13 & 6.5 \\
\hline Medum-High-technology manufactures & 0.12 & 6.0 & 0.25 & 15.5 & 0.65 & 15.1 & 0.34 & 20.4 & 0.38 & 16.6 & 0.31 & 24.9 & 0.29 & 26.3 & 0.38 & 20.6 & 0.40 & 19.7 \\
\hline Medium-Lowtechnology manufactures & 0.09 & 4.6 & 0.11 & 6.5 & 0.32 & 7.3 & 0.22 & 13.0 & 0.23 & 10.1 & 0.12 & 9.3 & 0.15 & 13.3 & 0.09 & 5.1 & 0.40 & 19.7 \\
\hline Low-technology manufactures & 0.15 & 7.6 & 0.05 & 3.1 & 0.90 & 20.8 & 0.28 & 16.8 & 0.42 & 18.2 & -0.03 & -21 & 0.24 & 221 & 0.00 & 0.1 & 0.12 & 5.9 \\
\hline Construction & 0.10 & 5.1 & -0.01 & -0.4 & 0.33 & 7.7 & 0.11 & 6.7 & -0.02 & -0.9 & -0.18 & -14.5 & -0.09 & -8.4 & -0.05 & -27 & 0.00 & 0.1 \\
\hline Wholesale and retail trade, restaurants and hotels & 0.09 & 4.5 & 0.23 & 13.8 & 0.44 & 10.2 & 0.05 & 2.9 & 0.41 & 17.9 & 0.14 & 11.0 & -0.18 & -16.4 & 0.55 & 29.3 & -0.05 & -25 \\
\hline Transports, storage, and cormunications & 0.58 & 29.1 & 0.20 & 124 & 0.56 & 13.0 & 0.24 & 14.2 & 0.48 & 20.8 & 0.04 & 29 & 0.23 & 20.4 & 0.19 & 9.9 & 0.34 & 16.7 \\
\hline Finance,insurance,real estate, \& business senvices & 0.44 & 22.2 & 0.34 & 20.9 & 0.62 & 14.4 & 0.15 & 9.2 & 0.21 & 9.0 & 0.40 & 31.5 & 0.12 & 11.2 & 0.16 & 8.8 & 0.63 & 30.7 \\
\hline Non-farmbusiness sector excl. non-market services & 1.99 & 100.0 & 1.64 & 100.0 & 4.31 & 100.0 & 1.68 & 100.0 & 232 & 100.0 & 1.26 & 100.0 & 1.11 & 100.0 & 1.86 & 100.0 & 206 & 100.0 \\
\hline Coefficient of variation & 0.63 & & 0.64 & & 1.04 & & 1.30 & & 0.88 & & 1.62 & & 1.95 & & 1.07 & & 1.24 & \\
\hline
\end{tabular}


close link between productivity growth and technological progress, cross-industry differentials are partly related to different patterns of innovative activity and adoption. Especially in industries that produce or use information and communication technologies (ICT), innovation and adoption are often driven by new entrants. Differences in industry-specific entry conditions across countries are likely to underlie some of the variance in industry productivity growth rates observed over the past two decades and in the industry specialisation of countries. ${ }^{4}$ At the same time, capital deepening in the face of labour market conditions adverse to the creation of low-skilled jobs (e.g. minimum wages) may partly explain the different sources of service productivity growth in Europe and the United States. The wide variance of productivity growth rates across industries and their potential dependence on industry-specific conditions (regulation, skill content, etc.) point, therefore, to the need to analyse the determinants of productivity at the detailed industry level. It should be stressed at the outset, however, that estimates of MFP are problematic for a number of service industries, especially in level terms, because of the way in which both output and inputs are measured. ${ }^{5}$

\subsection{Regulation and growth}

9. The main elements of the sweeping product market reforms implemented over the past two decades were privatisation, liberalisation of potentially competitive markets and pro-competitive regulation of natural monopoly markets. Reformers often argued that these reforms would improve corporate governance and increase competitive pressures, enhancing framework conditions for growth. To gauge whether reforms have indeed affected MFP and growth outcomes, through these channels, we use a new set of cross-country quantitative indicators of regulatory reform measuring regulation in particular areas, industries and overall. These indicators measure to what extent competition and firm choices are restricted in industries and areas where there are no a priori reasons to expect the government to interfere or where regulatory goals could plausibly be achieved by less coercive means and all of them range from 0 to 6 as policies become more restrictive of market mechanisms. ${ }^{6}$

10. Figure 1 summarises the various dimensions of regulation into a single policy indicator, which is useful to highlight the general patterns of reform (see below for details on how the indicator was constructed). The figure shows the evolution of this indicator over the past two decades. It presents succinctly the distribution of regulatory approaches in the OECD area and in the EU in selected years; and the chronologically juxtaposed boxes reveal the time-series aspects of the data, in particular the evolution of the median and the variance of the regulatory indicator. The figure suggests some policy convergence over the past two decades in absolute terms: on average, policies have become increasingly more friendly to market mechanisms. However, mainly due to differences in initial conditions and in the pace of reform, regulatory policies diverged in relative terms, with a widening variance of approaches across countries in the most recent period. Paradoxically, the recent divergence in policies is widest within the EU, despite efforts by the European Commission to harmonise the business environment in the Single Market.

4 Bassanini and Scarpetta (2002) discuss the links between ICT investment and productivity patterns. Scarpetta et al. (2002) analyse the role of entry in overall productivity growth in different manufacturing industries. Nicoletti et al. (2001) provide cross-country evidence on the link between entry regulations and industry specialisation.

5 For some service industries, output volume series are often based on an extrapolation of input measures, which are likely to generate a downward bias. Moreover, for those service industries that are heavy users of ICT, estimated MFP may be particularly problematic because ICT capital is adjusted, in some countries, for quality changes (via hedonic price deflators) but output measures are not.

6 The indicators have no ambition to measure the quality or the effectiveness (e.g. in terms of ability to achieve stated public policy goals) of the existing regulatory environment. 
ECO/WKP(2003)1

Figure 1. Regulatory reform
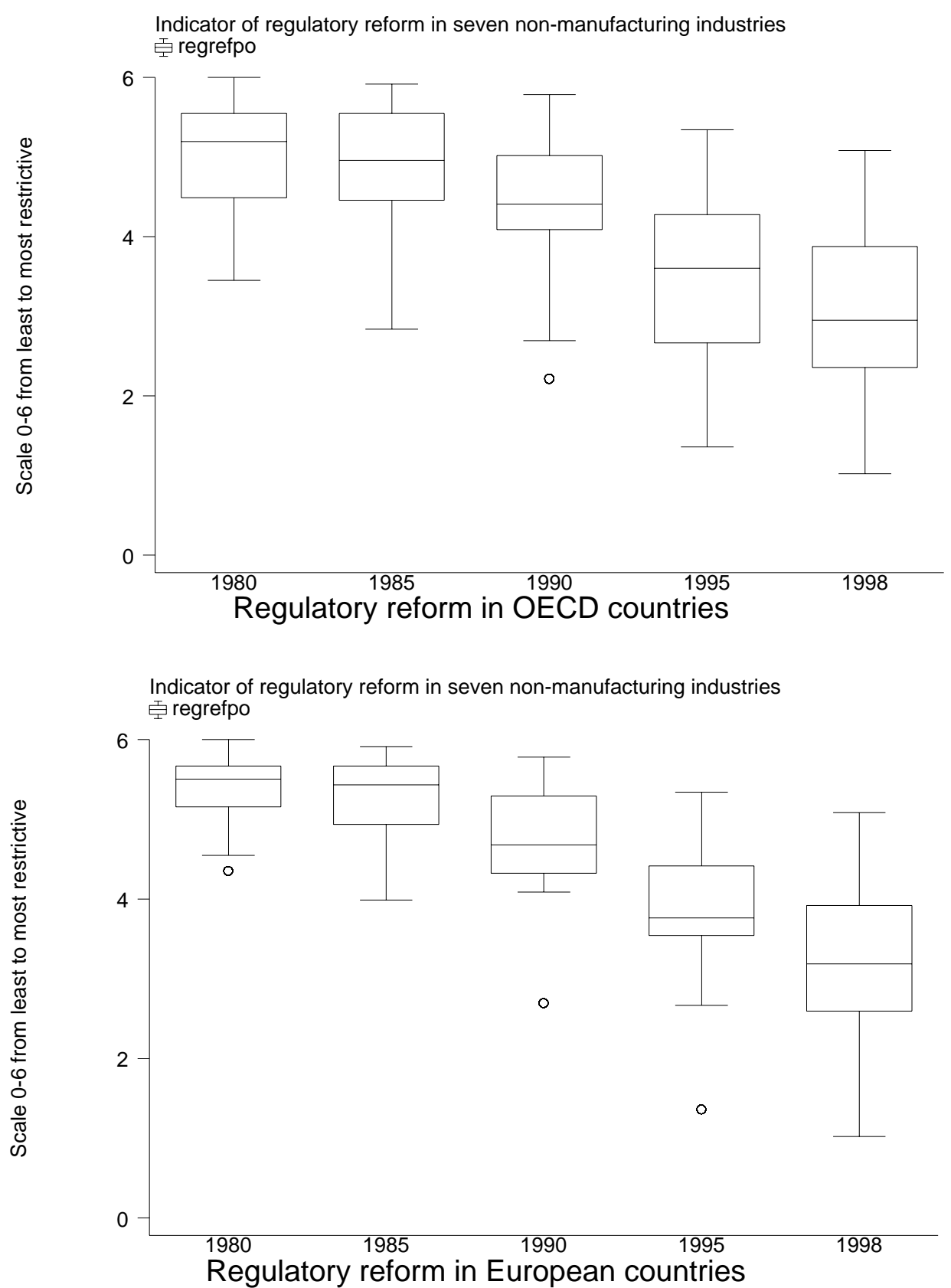

1. The box plot shows, in each year, the median OECD value of the regulatory indicator (the horizontal line in the box), the third and second quartiles of the cross-country distribution (the edges of each box) and the extreme values (the two whiskers extending from the box). Dots identify outlier observations. 
11. Did these differences in policies affect MFP outcomes? Simple bivariate relationships suggest that an anti-competitive regulatory environment and delays in implementing pro-market reforms, including improved market access and state retrenchment, are associated with relatively poor MFP performances (Figure 2). Over the past decade, many countries in which product market regulations remained unfriendly to competition (e.g. with relatively high values of the regulatory indicator) failed to overturn the generalised productivity slowdown of the 1970s and 1980s, while reforming countries often experienced a significant pick up in MFP growth. The acceleration in MFP growth is negatively correlated with three economy-wide measures of regulation and regulatory reform but, unsurprisingly, the correlation is strongest with the indicator of administrative burdens, which represent a uniform barrier to entry for businesses in most industries.

12. This bivariate evidence is supported by the industry-level multivariate empirical results presented in Section 4, which focus on public ownership and barriers to entry in competitive industries and (competitive segments of) network industries, the main source of variance in OECD regulatory settings. Regression estimates suggest that countries in which public ownership in the business sector is limited and barriers to entry are low are more successful at improving MFP than countries in which regulations curb competition and public enterprises are widespread. Regulations limiting private governance and competition (where these are viable) tend to lower long-run productivity potentials and, at least in manufacturing, their burden appears to be greater the further a given country is from best-practice technology. That is, strict regulation hinders the adoption of existing technologies, possibly by reducing competitive pressures, technology spillovers, or the entry of new high-tech firms. At the same time, by enhancing incentives and competitive pressures, both privatisation and entry liberalisation are estimated to have a positive impact on productivity.

13. All in all, these results on regulatory settings, privatisation and regulatory reform may shed some light on the observed differences in productivity growth patterns across OECD countries over the past two decades. The wide differences in the depth and scope of regulatory reforms across the two sides of the ocean, and even within Europe, may explain why some countries have been able to rebound from the long-run productivity slowdown, while in others productivity performance is still poor. The estimates suggest that the negative effects stemming from a more timid regulatory reform may have been particularly strong in those industries where European countries suffer from a significant technology gap (e.g. ICT-related industries).

\section{The role of ownership and competition in growth}

14. Multifactor productivity performance can be improved in three main ways: $i$ ) by eliminating slack in the use of inputs; ii) by adopting new technology; and iii) by innovative activity. Can product market regulation and public ownership curb the ability of firms to exploit successfully these channels of productivity improvement? Recent theoretical and empirical research suggests that this may well be the case to the extent that these policies influence (directly and indirectly) entrepreneurial incentives and competitive pressures. Therefore, looking at what is known about the linkage between governance arrangements, competition and performance provides clues on the ways in which regulation can have a bearing for productivity outcomes. 
Figure 2. Multifactor productivity acceleration and product market regulation

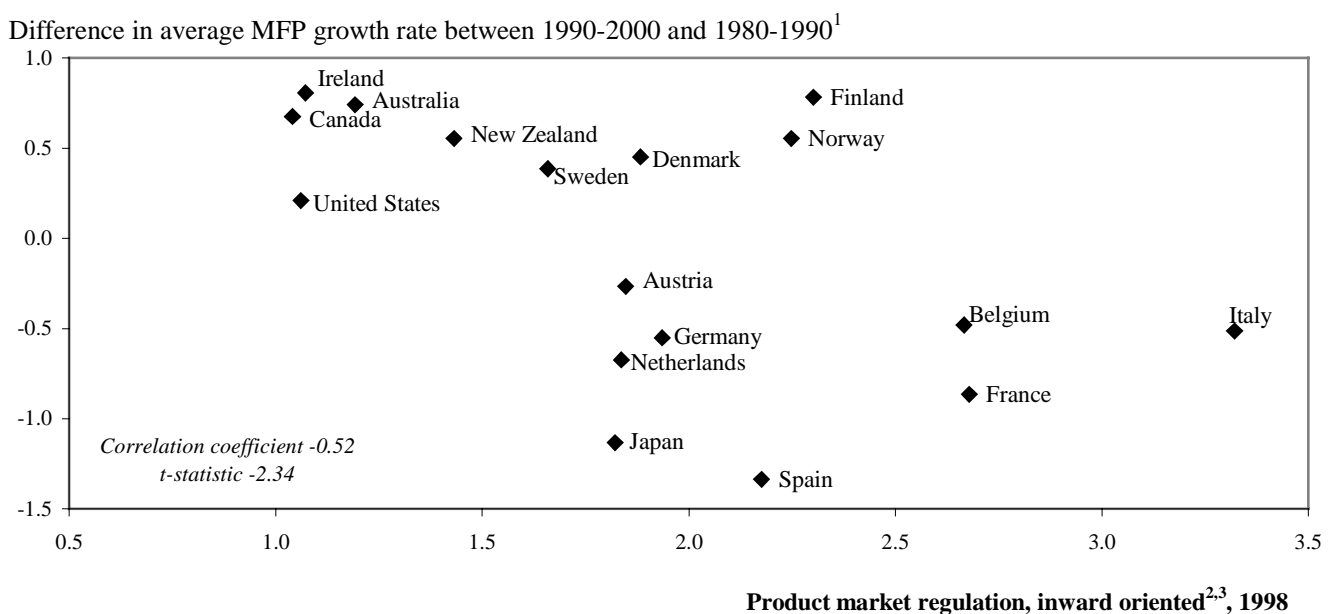

Difference in average MFP growth rate between 1990-2000 and 1980-1990 ${ }^{1}$
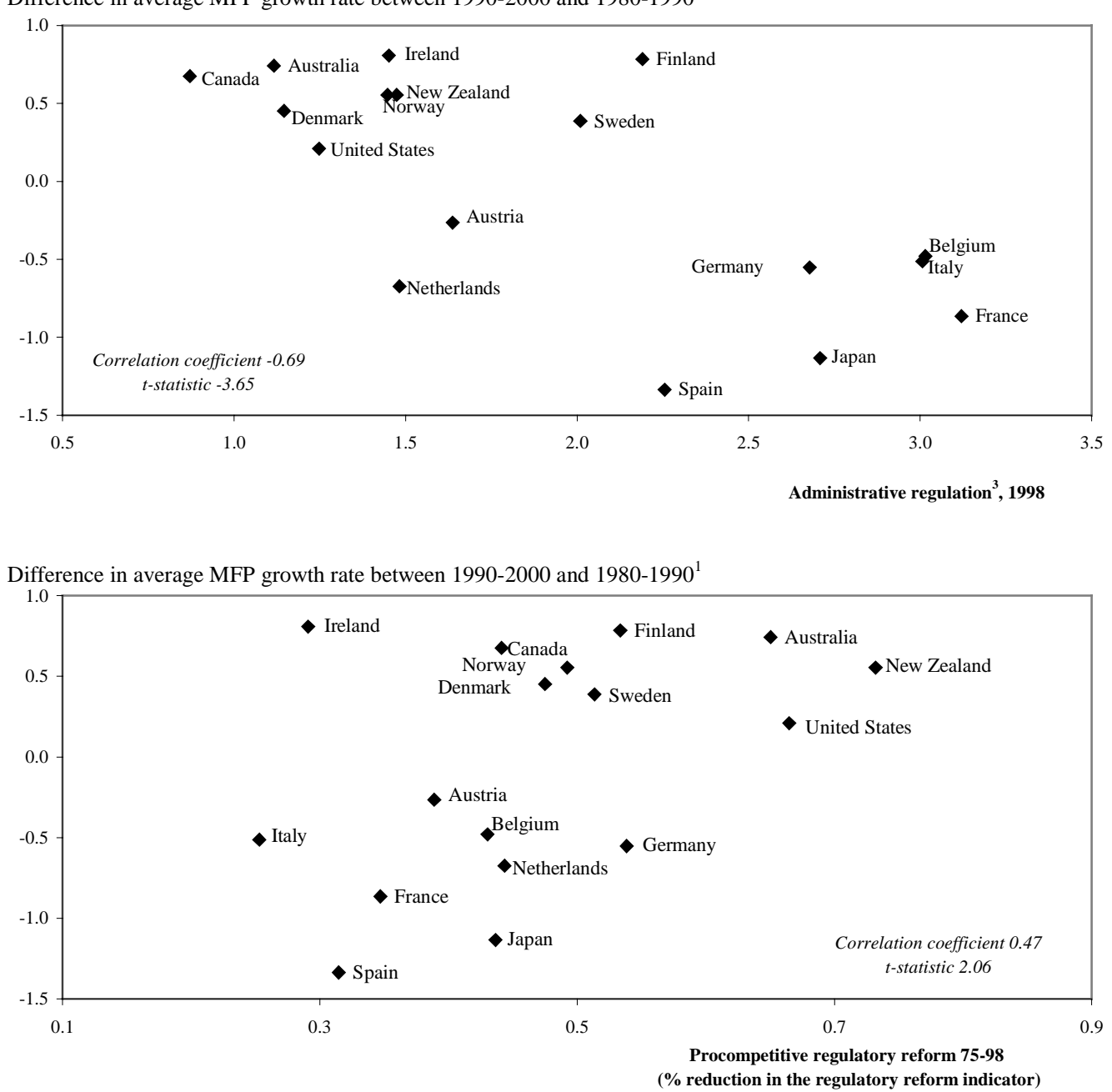

1. Adjusted for hours worked.

2. This is the simple average of the indicator of state control and barriers to entry and excludes barriers to trade and investment.

3. The scale of indicators is 0-6 from least to most restrictive. See Nicoletti et al. (1999). 


\subsection{Ownership and performance}

15. Privatisation policies are based on two main assumptions: $i$ ) private ownership of business enterprises is superior from the point of view of productive efficiency; and $i$ ) the risk of regulatory failure in network industries is reduced when direct control is replaced by arm's length regulation. The idea that ownership per se has positive implications for productive efficiency and the effectiveness of regulation has been fiercely debated in academic circles for several decades. ${ }^{7}$ Recent economic research has focused on three implications of privatisation that could justify the conjectured improvements in efficiency performance: $i$ ) changes in the behaviour of stakeholders; $i i)$ changes in agency relationships within the firm; and iii) changes in the insulating potential with respect to influence-seeking activities of organised pressure groups.

16. The behaviour of stakeholders is expected to change because the reallocation of property rights implied by privatisation is likely to affect both the objectives of owners and managers and the incentives for the former to monitor the latter. Incentives for monitoring, cost efficiency and innovation are believed to be stronger in private firms because the owners (or managers acting on behalf of the owners) can fully appropriate the benefits of monitoring, cost reductions or quality improvements, while in public enterprises these benefits ultimately accrue to tax-payers that have no direct control over the firm's choices. ${ }^{8,9} \mathrm{~A}$ multitude of empirical studies have tested these propositions indirectly, looking at the implications of differences (or changes) in ownership for company performance. In a recent paper in the Journal of Economic Literature, Megginson and Netter (2001) summarise the empirical evidence reaching the twin conclusions that "research now supports the proposition that privately owned firms are more efficient and more profitable than otherwise-comparable state-owned firms" and that "privatisation 'works', in the sense that divested firms always become more efficient". ${ }^{10}$

17. The main repercussion that privatisation may have on agency relationships is that the costs of aligning the objectives of managers and shareholders are likely to be reduced (see, e.g. Schmidt, 1996; Shleifer and Vishny, 1997). This is because company objectives are re-focused and a range of market signals and mechanisms becomes available for monitoring the performance of managers, including the information conveyed by stock prices, the threat of take-overs or bankruptcies and the existence of a managerial labour

$7 \quad$ As recently as the mid-1980s no consensus had been reached amongst analysts, and privatisation was termed "a policy in search of a rationale" (Kay and Thompson, 1986). For a summary of the theoretical debate around the ownership issue, see Laffont and Tirole (1993).

8 The property rights approach is summarised by Schleifer (1998). Shleifer and Vishny (1997) characterise state ownership as "an example of concentrated control with no cash flow rights and harmful social objectives".

9 Both the agency costs and property rights approaches focus on the influence of ownership on the behaviour of managers. However, ownership can also have an impact on the effort of workers. Haskel and Sanchis (1995) show that if the public owner maximises a social welfare function (comprising the welfare of workers) the outcome of the bargain between workers and managers is a level of effort which is lower (i.e. larger X-inefficiency) in public enterprises than in private enterprises, where managers maximise profits.

10 In addition, a handful of studies has directly tested the predictions of the property rights theory, exploring the determinants of changes in performance, often based on the experience of transition countries (Claessens et al., 1999; Frydman et al., 1999; D'Souza et al., 2000). Their empirical findings suggest that corporate objectives tend to be sharper, and efficiency incentives are stronger the more residual rights are allocated to investors interested in shareholders' value maximisation. 
market. ${ }^{11}$ For example, Cragg and Dyck (1999) relate the increased frequency of management turnover in British privatised firms to an increased sensitivity of owners to the failure by managers to reach established objectives. Related evidence is provided by D'Souza et al. (2000) and Eckel et al. (1997) who find that enterprise restructuring (including changes in management and in monitoring devices) is an important determinant of post-privatisation efficiency gains.

18. Political economy studies have recently strengthened the case for privatisation, suggesting that private ownership can also deal more efficiently with influence-seeking activities. For instance, when the ability of politicians to subsidise private firms is restricted (e.g. due to the negative political repercussions resulting from the financing of such subsidies) resource allocation is improved by privatisation, because shareholders of profitable enterprises are less willing than public managers to accept the inefficiencies sought by interest groups. Similarly, privatisation may make it politically costlier for ministers in charge of industrial policies to implement exchanges with special interest groups (such as excess employment against votes) because for the minister it is easier to pay for the implied productive inefficiencies using the foregone profits of public enterprises rather than having to lobby with the Treasury (and compete with other ministries) to obtain the subsidies that would be needed to induce a private enterprise to hire excess labour. ${ }^{12}$

19. These studies suggest that, at any given level of competition in the market supplied by the privatised firm, the change in ownership tends to increase the incentives to monitor, refine monitoring devices and increase the insulation of management from the influence of pressure groups. Hence, a positive impact on productive efficiency can be expected. However, in network industries, privatisation and arms' length regulation may not be able to bring these expected benefits. This is because ownership and control may remain distant (due to the frequent incorporation of privatised utilities as public companies), new agency problems may arise (due to the multiple-principal situation engendered by the additional control rights of the regulator) and political interference may persist (due to the strategic role played by utilities and the near coincidence between their customers and the electorate). In these industries, the effects of privatisation are closely related to the creation of sufficient market pressures in the potentially-competitive segments of the industry and to the regulation of access to the non-competitive segments. Lack of competition in upstream or downstream markets can thwart the incentives for productivity improvements. ${ }^{13}$ An ill-designed access regulation can distort the investment incentives of the company running the network, with potentially negative consequences on productivity. Therefore, especially in industries with natural monopoly elements, the impact of privatisation on efficiency is still largely an empirical matter to be verified at the industry or firm level.

\subsection{Competition and performance}

20. While privatisation may lead to an improvement in the level of productive efficiency of the firms involved, policies aimed at enhancing market competition (e.g. by removing barriers to entry in potentially

11 However, if the managerial market is common to private and public sectors, public and private managers may be subject to similar pressures related to reputation (Estrin and Pérotin, 1991). On the other hand, objective-related compensation schemes (such as performance bonuses and stock options), which may help establish correct sets of incentives for managers of private firms, are usually unavailable to public managers.

12 In other words, privatisation forces the politicians to internalise the cost of the productive inefficiencies, thereby changing their preferred outcome (Shleifer and Vishny, 1994; Boycko et al., 1996).

13 Of course lack of competition also has negative implications for allocative efficiency, which however is outside the scope of this study. 
competitive markets) are expected to have more widespread effects on both static and dynamic efficiency. Static gains are related to the elimination of x-inefficiencies as the monopolists' "quiet life" habits are stirred by competitive pressures. Dynamic gains are also likely as firms continue to improve their performance in ways they would not have had competitive pressures been weak (Winston, 1993; Meyer and Vickers, 1997). At least three different channels leading to dynamic efficiency improvements can be identified. First, competition creates greater opportunities for comparing performance, making it easier for the owners or the market to monitor managers. Second, cost-reducing improvements in productivity could generate higher revenue and profit in a more competitive environment where the price elasticity of demand tends to be higher. Third, since more competition is likely to raise the risk of losing market shares at any given level of managerial effort, managers may work harder to avoid this outcome. ${ }^{14}$

21. The effects of product market competition on dynamic efficiency may also arise indirectly via the incentives to innovate, but this channel is not straightforward. The basic Schumpeterian model suggests that innovation and growth are declining with competition because the monopoly rents from innovation tend to be dissipated more quickly when there is stronger competition. However, extensions of this model yield a more complicated picture (Aghion and Howitt, 1998; Boone, 2000a). Intensified competition may force managers to speed up the adoption of new technologies, in order to avoid loss of control rights due to bankruptcy. Even when firms have similar cost structures (the case of "neck and neck" competition) and technological progress is more gradual, stronger competition may induce firms to increase R\&D investment in order to acquire a lead over their rivals.

22. The empirical evidence supporting these theoretical considerations is still fairly limited and not always univocal. A positive relationship between competition and innovative activity (at each given level of protection of intellectual property rights) was found by Nickell (1996), Blundell et al. $(1995,1999)$ and Bassanini and Ernst (2002), though Aghion et al. (2001) present evidence that support a hump-shaped relationship. ${ }^{15}$ A number of studies report a positive impact of domestic competition on firm-level productivity in the United Kingdom (Nickell, 1996; Blanchflower and Machin, 1996; Nickell et al., 1997; Disney et al., 2000). Other studies find a positive link between technical efficiency and competition at the firm-level (Caves and Barton, 1990; Caves et al. 1992; and Green and Mayes 1991) or at the industry-level (e.g. Porter, 1990; McKinsey Global Institute, 1997; Baily and Gerbach, 1995; and several articles in OECD, 2001b). Trade liberalisation is also found to have positive effects on both the level and growth rates of productivity (e.g. MacDonald, 1994; Van Wijnbergen and Venables, 1993). These studies tend to conclude that domestic and international competition (proxied by market concentration, size of rents, import penetration rates, etc.) is key for productivity improvements. ${ }^{16}$

23. In this paper we adopt a different strategy. Instead of using proxies for product market competition, such as concentration indices, mark-up estimates or measures of trade openness, we look at some of the potential determinants of competition. Looking at policies that affect competition rather than attempting to

14 These channels are highlighted by Lazear and Rosen (1981), Nalebuff and Stiglitz (1983) and Aghion and Howitt (1998).

15 The interplay between innovation incentives and competitive pressures may indeed result in a hump-shaped relationship (Aghion et al., 2001). Perfect competition makes firms indifferent vis-à-vis the choice whether to innovate or not, but the possibility to appropriate rents coupled with competitive struggle makes innovation desirable. When rent protection becomes strong enough, incentives to innovate fade out again. Therefore, if a market moves from monopoly to perfect competition, innovative activity may first increase and then decrease.

16 Baily and Gerbach (1995) also point to the importance of 'global competition'-that is, exposure to the best producers wherever they are located-for productivity growth. 
measure directly market pressures has conceptual and empirical advantages. First, direct measures of competition, such as indices of concentration or mark-ups, are plagued with problems of interpretation and accuracy. Notably, such pressures should be measured at the level of relevant markets, which are difficult to circumscribe, and standard measures are not always monotone in the degree of competition. ${ }^{17}$ Second, direct measures are often endogenous to outcomes. For instance, usual measures of MFP are directly related to the remuneration of factors of production. ${ }^{18}$ Finally, direct measures are not interpretable in terms of policies: for instance, finding an effect of market power on MFP does not provide indications on which policies should be followed to improve outcomes. Regulations are less affected by these shortcomings: they generally have a univocal and across-the-board impact on competition and they bear a direct link to policy. Moreover, over reasonable lapses of time, they can be assumed to be exogenous, especially to MFP outcomes that are usually reported with lags and often bear little relationship with more timely measures of productivity (see above). ${ }^{19}$

\section{Product market regulation, governance and competition in OECD countries}

24. Emphasis on privatisation and domestic and international competition has been the leitmotiv of structural reform over the last quarter of century. Summary measures of the evolution of the business environment in OECD product markets indeed point to an increasing pro-market orientation in most countries. For instance, the index provided by the Fraser Foundation (Economic Freedom of the World), which is partly survey-based, moved towards a more competitive environment in all the major OECD regions since $1975 .^{20}$ A number of studies have documented the generalised effort of regulatory reform as well as reforms in specific industries. ${ }^{21}$

25. How did differences in the pace and the scope of reform affect the international and inter-industry patterns of regulation? Here we provide a tentative answer to this question focusing on a new set of indicators constructed at the OECD that covers both economy-wide and industry-specific regulations. ${ }^{22}$ It is

17 For example, Boone (2000b) suggests that there may be a hump-shaped relationship between the degree of product market competition and mark-ups.

18 Amongst the very few cross-country studies that explore the role of competition on productivity, Cheung and Garcia Pascual (2001) use mark-ups and concentration indexes. At the firm-level, Nickell (1996), Nickell et al. (1997) and Disney et al. (2000) use market share indicators to capture competitive pressures. However, the potential problem of endogeneity is even more serious with firm-level data, insofar as high-productivity firms may gain market shares and enjoy innovation rents.

19 Several recent studies show that regulatory decisions can be influenced by performance outcomes. The latter, however, are usually timely and straightforward indicators such as prices or labour productivity. See, for instance, Steiner (2001) concerning reforms in the electricity supply industry, and Duso and Röller (2001) concerning reforms in the telecommunications industry.

20 The Economic Freedom of the World index, which measures the market friendliness of policies on a 0-10 scale (from least to most market friendly), increased by 12 per cent in North America, 30 per cent in Europe, 14 per cent in Japan and 44 per cent in Australia-New Zealand since 1975. The index has a broad and eclectic coverage, going from the size of government to the rule of law. It includes information on policies, market outcomes and business sentiment. For details, see Gwartney and Lawson (2001).

21 See, for instance, the papers in Oxford Review of Economic Policy (2001), OECD (2001b) and the references therein, as well as the country experiences reported in the OECD Reviews of Regulatory Reform.

Some of the basic data used to construct these indicators are available on the OECD website. Other data can be found in Nicoletti et al. (1999), Gonenç et al. (2001) and Nicoletti et al. (2001). 
important to note at the outset that the primary aim of these indicators was to report restrictions to competition and private governance. Thus, the weights given to the various regulatory provisions they cover reflect the potential importance of regulations for these outcomes. The indicators were not constructed expressly to measure the effects of such restrictions on MFP or other specific economic variables. ${ }^{23}$

26. Assessing and comparing across countries the friendliness of regulatory policies to competition involves conceptual and interpretative issues. While it is relatively easy to point out broad policy measures aimed at increasing market openness and competitive pressures (e.g. trade liberalisation, administrative simplification), the impact on incentives and competition of some aspects of regulatory reform is less easy to assess. For instance, the extent to which privatisation increases market pressures on the management of privatised firms is somewhat controversial. Similarly, the jury is still out on precisely which regulatory policies are conducive to stronger competition in industries where potentially-competitive markets coexist with elements of natural monopoly. ${ }^{24}$ Moreover, turning qualitative information concerning regulations into quantitative data necessary involves assumptions, simplifications and subjective choices. This section addresses these issues by summarising how the indicators were constructed, checking their robustness to changes in assumptions and methods and, especially, highlighting the emerging patterns of regulatory reform. A complete taxonomy of the indicators and further details about methodology and sensitivity can be found in the appendix.

\subsection{Summarising the regulatory environment}

27. There are two main areas of regulation that are likely to have an impact on governance and/or product market competition:

- Provisions that aim at establishing partial or full state control over resources or economic activities that could, in principle, be managed by private agents (e.g. public ownership and/or control, restrictions on price setting and/or other firm's choices).

- Provisions that create barriers to entrepreneurship in domestic markets, where fixed costs, technology and demand conditions make competition viable. These barriers may originate either from explicit attempts to carve the structure of markets or from provisions that have (intentional or unintentional) effects on entry. They include laws or regulations limiting the number of competitors or providing an unfair advantage to some of them (such as antitrust exemptions); structural arrangements that make it difficult for competitors to access fixed networks (e.g. vertical integration); regulatory and administrative burdens that impose fixed costs on businesses; and policies that create impediments to international trade and investment (such as foreign investment restrictions and tariff and non-tariff barriers).

28. Focusing on these two broad areas, we aim at highlighting three main types of cross-country patterns of regulation potentially relevant for explaining differences in productivity performance. First,

23 The indicators are "multipurpose" and have been used to investigate various channels through which regulation may affect economic outcomes, ranging from R\&D (Bassanini and Ernst, 2002) to wage premia (Jean and Nicoletti, 2002) and employment (Nicoletti and Scarpetta, 2001).

Open issues include which access provisions to networks maximise the benefits of competition in the provision of downstream services; what degree of vertical separation of utilities minimises the incentives for anticompetitive behaviour by incumbents; and what kind of retail price regulation (if any) maximises the passthrough of efficiency gains from upstream competitors to final consumers. 
specific regulatory interventions may exist in some countries, but not in others (e.g. public enterprises, restrictions to entry or price controls in certain potentially competitive markets). Second, regulatory provisions to overcome market failures may exist everywhere (e.g. barriers to entry in natural monopoly industries or screening procedures for start-ups), but their stringency may differ across countries. Third, the scope of regulations designed to promote competition in network industries (e.g. vertical separation or access pricing) can also differ across countries. It is important to note that the construction of our indicators is based on the hypothesis that regulatory patterns do not reflect cross-country differences in the level of public concern for the market failures that motivate regulations, but rather reflect regulatory failure or policies adverse to competition. Concretely, for example, heavier administrative burdens for start-ups in one country are assumed to reflect regulatory inefficiency rather than higher quality screening of firms. This seems a reasonable assumption since the focus is on differences in regulation across a set of relatively homogeneous countries in terms of economic, political and social characteristics.

29. To highlight these patterns, we look at both general-purpose and industry-specific regulations (Table 3). The former tend to affect all industries alike, such as administrative burdens or antitrust exemptions for public enterprises. The latter are tailored to specific industries (or sets of industries). Indeed, many regulations are industry-specific and may be expected to have different effects on governance and competition across industries. Therefore, to analyse the effects of regulation on productivity, it is crucial to look at both these dimensions of regulation.

Table 3. Overview of regulatory indicators ${ }^{1}$

\begin{tabular}{|c|c|c|c|}
\hline \multirow[t]{2}{*}{ Indicator } & \multicolumn{2}{|c|}{ Coverage } & \multirow[t]{2}{*}{ Period } \\
\hline & Sectoral detail & Regulatory areas & \\
\hline \multirow{3}{*}{ Economy-wide regulation } & \multirow{3}{*}{$\begin{array}{l}\text { Summary of general-purpose } \\
\text { and industry-specific } \\
\text { regulations }\end{array}$} & $\begin{array}{l}\text { State control, barriers to } \\
\text { entrepreneurship }\end{array}$ & \\
\hline & & $\begin{array}{l}\text { Economic regulation, } \\
\text { administrative regulation }\end{array}$ & 1998 \\
\hline & & $\begin{array}{l}\text { Barriers to international trade } \\
\text { and investment }\end{array}$ & \\
\hline Privatisation & $\begin{array}{l}\text { Aggregate business sector and } \\
\text { seven } 2 \text { or } 3 \text {-digit non- } \\
\text { manufacturing industries }\end{array}$ & Public ownership ${ }^{2}$ & $1975-1998$ \\
\hline \multirow{2}{*}{ Industry-level regulation } & $\begin{array}{l}\text { Industry-specific barriers to } \\
\text { international trade in } \\
\text { seventeen 2-digit } \\
\text { manufacturing industries }\end{array}$ & Tariff and non-tariff barriers & $\begin{array}{c}1988,1993 \\
1996\end{array}$ \\
\hline & $\begin{array}{l}\text { Industry-specific regulations in } \\
\text { seven } 1 \text { or } 2 \text {-digit non- } \\
\text { manufacturing industries }\end{array}$ & $\begin{array}{l}\text { Public ownership, barriers to } \\
\text { entry }{ }^{5} \text {, constraints to business } \\
\text { operation, price controls }\end{array}$ & 1998 \\
\hline Regulatory reform & $\begin{array}{l}\text { Summary of industry-level } \\
\text { regulations in seven } 2 \text { or } 3 \text {-digit } \\
\text { non-manufacturing industries }\end{array}$ & $\begin{array}{l}\text { Public ownership, barriers to } \\
\text { entry }^{5} \text {, price controls }\end{array}$ & $1975-1998$ \\
\hline
\end{tabular}

1. All indicators are increasing in the degree of restrictions imposed on market mechanisms. See appendix for further details on sources, definitions, coverage and aggregation procedures

2. The business sector measure proxies the share of public-controlled firms in non-agricultural business sector GDP. The indicator for non-manufacturing industries summarises the degree of public control in each industry.

3. Based on 6-digit data on tariff and non-tariff barriers. See appendix for details on aggregation procedures.

4. Based on data for fifteen 2 or 3-digit non-manufacturing industries. See appendix for details on the coverage of indus and areas of regulation.

5. In network industries, includes the degree of vertical integration and the market share of the incumbent. 
30. A further distinction must be made between economy-wide and industry-level regulatory indicators. The former summarise information on both general-purpose and (possibly) industry-specific regulations into a single indicator for each country, the latter summarise information concerning specific regulatory provisions that affect a single industry. The economy-wide indicators have a wider coverage of regulatory areas than the industry-level indicators, because they do not cover necessarily regulatory details in all individual industries. ${ }^{25}$ For instance, they take an extensive view of state control and barriers to entrepreneurship, including indirect forms of control (such as the use of golden shares in privatised enterprises) and indirect entry barriers (such as antitrust exemptions and discriminatory licensing procedures).

31. The areas and dimensions of regulation accounted for by the industry-level indicators depend on both industry characteristics and data availability (details are provided in the appendix). They generally cover public ownership — narrowly defined as majority control over business enterprises-and barriers to entry-including legal and structural barriers, administrative burdens and trade impediments, with a different weight given to these factors in manufacturing and non-manufacturing industries (see Box 2). However, in several non-manufacturing industries (e.g. retail trade, road freight, railways, energy, communications) we also include other provisions, such as price regulation and/or constraints on business operation (e.g. shop opening hours, cabotage, etc.) and we ignore public ownership where it is either irrelevant (e.g. in retail trade) or difficult to assess (e.g. in financial intermediation) in virtually all OECD countries.

32. The construction of economy-wide and industry-level indicators involved turning sparse and mostly qualitative information into cardinal values that allow ranking countries' regulations according to their potential impact on governance and competition. We did so following a multi-step, bottom-up approach (see the appendix for details):

- We first constructed indicators for each of the regulations covered by our data, ranking countries on a common (0-6) scale from least to most restrictive. Thus, all indicators have a consistent ordinal meaning, i.e. they are all increasing in the degree of restrictions imposed by regulation on competition or private governance. ${ }^{26}$

- We also identified coherent sets of regulations in an area (e.g. state control or administrative regulation) or industry. This was necessary because comparing individual regulatory provisions across countries is possible, but it is of little use in empirical analyses. Moreover, individual provisions in an area (e.g. administrative procedures needed for a start-up) or industry (e.g. the regulation of access pricing) cannot be assessed in isolation from other regulations affecting the same area (e.g. the existence of one-stop shops) or industry (e.g. the degree of vertical separation of natural monopoly and competitive segments).

25 See the appendix for a complete taxonomy of the economy-wide and industry-level indicators.

26 For instance, industry-specific indicators of price regulation in network industries assign a low ranking to countries that have adopted a price cap mechanism in non-competitive markets (because such a mechanism tends to discipline rents) and a high ranking to countries that have no price regulation (or discretionary price regulation) in such markets. Conversely, industry-specific indicators of price regulation in competitive industries (e.g. road freight) assign a low ranking to countries that have no price regulation and a high ranking to countries where administrative controls exist. 


\section{Box 2. Differentiating anticompetitive regulations across industries}

We treated barriers to entry in manufacturing and non-manufacturing industries differently, reflecting structural differences between the two sectors. In non-manufacturing, we cover mainly legal and structural barriers-such as restrictive licensing, restrictions on the establishment of foreign companies, legal monopoly (or duopoly), and vertical integration or lack of third-party access in network industries. In manufacturing industries we assumed that relevant barriers included only administrative burdens and tariff and non-tariff barriers to trade. Clearly, the range of industryspecific regulations that may affect product market competition in manufacturing industries is wider (including, for instance, technical or quality standards, intellectual property rights and antitrust exemptions). However, cross-country information on these regulations is hard to find, and their impact on competition is often difficult to assess.

As regards price controls, we distinguished between competitive industries and industries where market power is widespread (e.g. due to technology): while we regard controls in the former as anti-competitive (especially when enforced by incumbents), we view controls in industries with market power as anticompetitive when they fail to discipline rents, lead to distortions (e.g. the so-called Averch-Johnson effects) or encourage anticompetitive behaviour (e.g. opportunities for cross-subsidisation and predation). A distinction along the same lines is made for other constraints on business operation. In competitive industries, such constraints are deemed to restrict market mechanisms, but universal service obligations are not included among anti-competitive regulations in network industries. This is because, in general, it is not the obligation per se but the way in which it is implemented that may hinder competition in certain network industries (see, for instance, Gonenç et al., 2001) and, unfortunately, cross-country data on the implementation of universal service obligations are not widely available. ${ }^{1}$

One outstanding problem with measuring the anti-competitive impact of regulations is the potential hiatus between legal provisions and enforcement. Stringent regulations may not bite on competition if they are not enforced and, conversely, even the most liberal regulations may not promote competition if their provisions (e.g. concerning access to networks or administrative procedures) are not concretely implemented. Relatedly, national laws may have little bearing for markets when their application depends on local authorities, or when local legislation can be opposite in spirit. In our work, we try to account for the impact of formal regulatory frameworks on market mechanisms at the industry level by including measures of actual market and industry structure in the summary indicators (when the data are available). ${ }^{2}$ The measures used include the market shares of new entrants, the extent of industry unbundling and the share of equity owned by the government. This, of course, does not take care of the potential conflict between national and local levels of government. ${ }^{3}$

1. A typical example is the obligation for an incumbent to provide service to some customers at prices below cost while funding the losses with rents earned from the sale of other services.

2. However, market structure information is omitted from the indicators used in the productivity regressions to avoid endogeneity problems.

3. An alternative approach would have been to forego the "objective" measurement of regulation in favour of "subjective" measures based on business or consumer surveys. We view the subjective approach as unpromising for many reasons. First, it cannot reach the same level of detail as the objective measures. Second, survey results suffer from various sources of bias, notably they are influenced by cultural and socio-political environment, cyclical swings and other factors difficult to control for. Third, because of this, the cross-country comparability of the results is questionable. Fourth, while objective measures can be deemed to be "exact" (apart from, hopefully small, measurement error), subjective measures are subject to sampling error. A fuller discussion of the relative merits of "objective" and "subjective" measures of regulation can be found in Nicoletti and Pryor (2001). 
- We then aggregated the resulting indicators into area-wide or industry-wide indicators using simple or weighted averages, adapting the aggregation methods to the question asked and the availability of data. In particular, whenever possible, we used factor analysis to determine the weight structure (see appendix for details). ${ }^{27}$

- Finally, we repeated aggregation for progressively larger areas or industry groupings to obtain the summary indicators used in the empirical analysis.

33. This approach implies that the summary indicators of regulation are based on detailed qualitative information concerning individual regulatory provisions. ${ }^{28}$ The advantage is that the relative position of a country along an area-wide or industry-wide indicator can be traced to the country's relative positions in each of the underlying regulations covered by the summary indicator. Another advantage is that indicators can be aggregated (or disaggregated) differently to suit the particular purpose of the empirical analysis. For example, while in this section we use all regulatory dimensions to describe the cross-country patterns of regulation, in the econometric analysis we focus only on the effects of public ownership and barriers to entry on MFP.

34. An important element of our analysis is the time pattern of public ownership and regulatory reform. To account for differences in both the initial levels of public ownership and its evolution over time, we used information on the shares of public enterprises in business sector activity and aggregate privatisation proceeds over the past two decades. ${ }^{29}$ The resulting dynamics of public ownership proxies for general trends in state retrenchment. Regulatory reform has concerned both international trade in manufactured goods and domestic non-manufacturing markets. On the trade side, we constructed series for tariff and non-tariff barriers at the 2-digit and aggregate manufacturing levels since the second-half of the 1980s. Cross-country historical information on domestic regulations in non-manufacturing is scarce, but we were able to collect such data for seven industries, covering the energy, transport and communications sectors, which account for a significant share of non-manufacturing and constitute an important input into manufacturing activities. Though the regulatory areas covered by these data change across industries, they include in all cases barriers to entry. ${ }^{30}$ The industry-specific information about the dynamics of regulatory

27 Factor analysis was used as a descriptive device to identify clusters of regulatory provisions belonging to the same (unobserved) regulatory sub-areas and determine the weights of individual regulations for economywide indicators and certain industry-level indicators for which a large amount of data concerning different areas of regulation were available.

28 The basic information can, therefore, be recovered easily for the purpose of cross-country comparisons or empirical estimation (for instance to create dummies that isolate cross-country differences in basic regulatory provisions).

29 Initial shares of public enterprises were drawn from several sources (OECD Economic Surveys, EBRD Annual Reports, the tri-annual reports of the Centre Européen des Entreprises à Participation Publique CEEP, the annual reports of Economic Freedom of the World), data on privatisation proceeds comes from the OECD Privatisation Database. We make assumptions to convert yearly privatisation proceeds into foregone shares of public enterprises in GDP.

30 UNCTAD reports data on tariff and non-tariff barriers at the 6-digit level for 1988, 1993 and 1996. Aggregates for 2-digit industries were computed using import weights, the manufacturing aggregate was obtained using sectoral value-added weights. Several published and unpublished sources were used to complete and cross-check the available information on domestic non-manufacturing regulations. These included publications of the OECD, the European Conference of Ministers of Transport, the EC, the World Bank, the Center for the Study of Regulated Industries/Privatisation International. See the appendix for details on methods and sources. 
reform was used to differentiate developments in manufacturing and services (pooling together developments in several sub-sectors). The data appendix provides more details about the construction of the time-series indicators.

\subsection{What are the emerging regulatory patterns?}

35. The three panels in Figure 3 describe overall public ownership and privatisation, liberalisation of trade in manufactured goods and regulatory reform in non-manufacturing industries by means of the economy-wide and industry-level indicators of regulation, focusing on the sample of core OECD countries analysed in this paper.

36. Public ownership (measured on a 0-6 scale, from the lowest to the highest share of GDP) varied widely at the beginning of the period, with most continental European countries, Ireland and New Zealand having between 20 and 30 per cent of non-agricultural business sector GDP produced by public enterprises against a mere 1 to 10 per cent in the United States, Japan and Switzerland (Figure 3, Panel A). Privatisation affected virtually all countries but to very different degrees: the most spectacular reductions in public ownership occurred in Portugal, New Zealand, Australia and the United Kingdom. These aggregate data mask wide differences in both the sectoral presence of public enterprises and cross-sectoral patterns of privatisation. While public enterprises initially played an important role in non-manufacturing natural monopoly industries of most OECD countries, in only a few (including some large European countries) their presence was also significant in the manufacturing sector. ${ }^{31}$ Moreover, a closer look at the evolution of OECD privatisation proceeds by sector suggests a pattern in which a first wave of sell-offs of manufacturing firms was followed by widespread divestitures in non-manufacturing (and natural monopoly) industries (OECD, 2001c).

37. In manufacturing, regulatory reform concerned mostly administrative simplification and trade liberalisation. According to a recent survey, a majority of OECD countries had programmes aimed at easing administrative burdens on firms already underway at the end of the 1990s. ${ }^{32}$ Trade liberalisation involved both a reduction in tariffs and an alleviation of non-tariff barriers (such as voluntary price or export restraints, restrictive licensing and quotas). We concentrate on the latter because, as a result of trade negotiations mainly concerning tariffs, non-tariff barriers have acquired greater importance and often constitute genuine barriers to entry in domestic markets. Figure 3 (Panel B) shows that the share of imports affected by non-tariff barriers has declined in almost all countries, particularly in Australia and New Zealand (from already low levels in the late 1980s), and in the United States and some European countries (from high levels). Nonetheless, in 1996 barriers remained significant in many OECD countries.

31 In 1998, between 80 and 90 per cent of OECD countries (depending on the industry) still had public enterprises in natural monopoly industries, while only half of them had public enterprises in manufacturing (Gönenç et al., 2001). Within the EU, only Sweden, Finland and France were estimated to have more than 2 per cent of manufacturing GDP produced by public enterprises (authors' estimates based on data by CEEP, 2000).

32 Data from the OECD International Regulation Database suggests that over 90 per cent of countries had explicit programmes to reduce administrative burdens and over 60 per cent had programmes underway to reduce the number of licenses and permits required to start and operate a business. 
Figure 3. Privatisation and regulatory reform in OECD countries ${ }^{1}$

Panel A. Public ownership and privatisation

$0-6$ indicator from lowest to higher share of public entreprise ${ }^{1}$

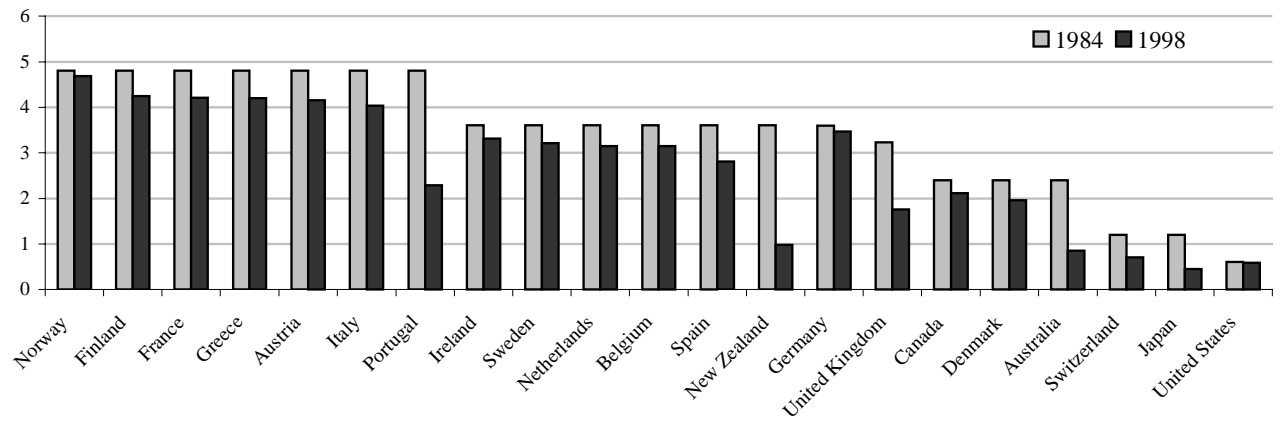

Panel B. Manufacturing trade liberalisation

Import coverage non-tariff barriers ${ }^{2}$

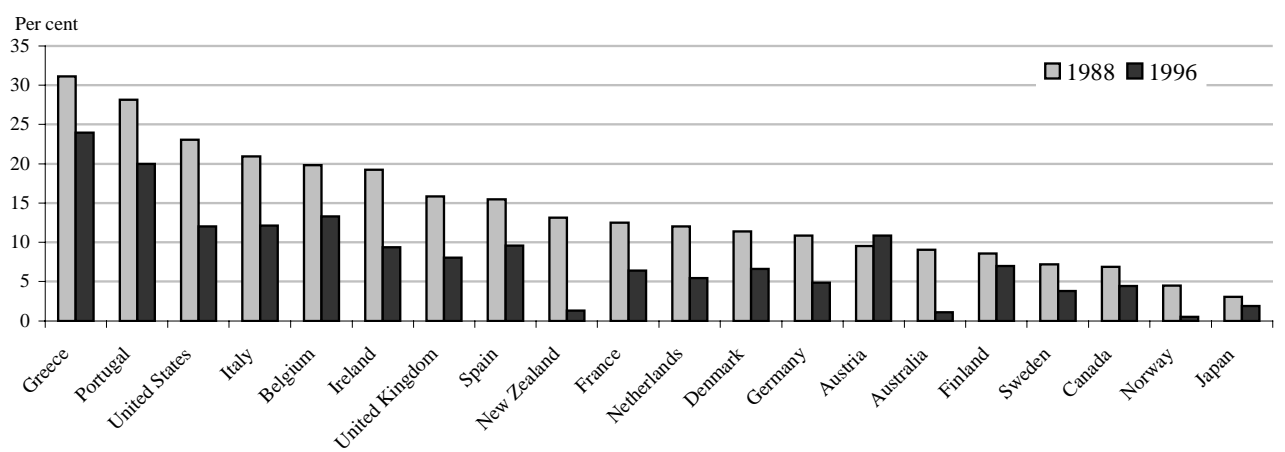

Panel C. Regulatory reform in selected non-manufacturing industries, 1975-1998 ${ }^{3}$ $0-6$ indicator from least to most restrictive

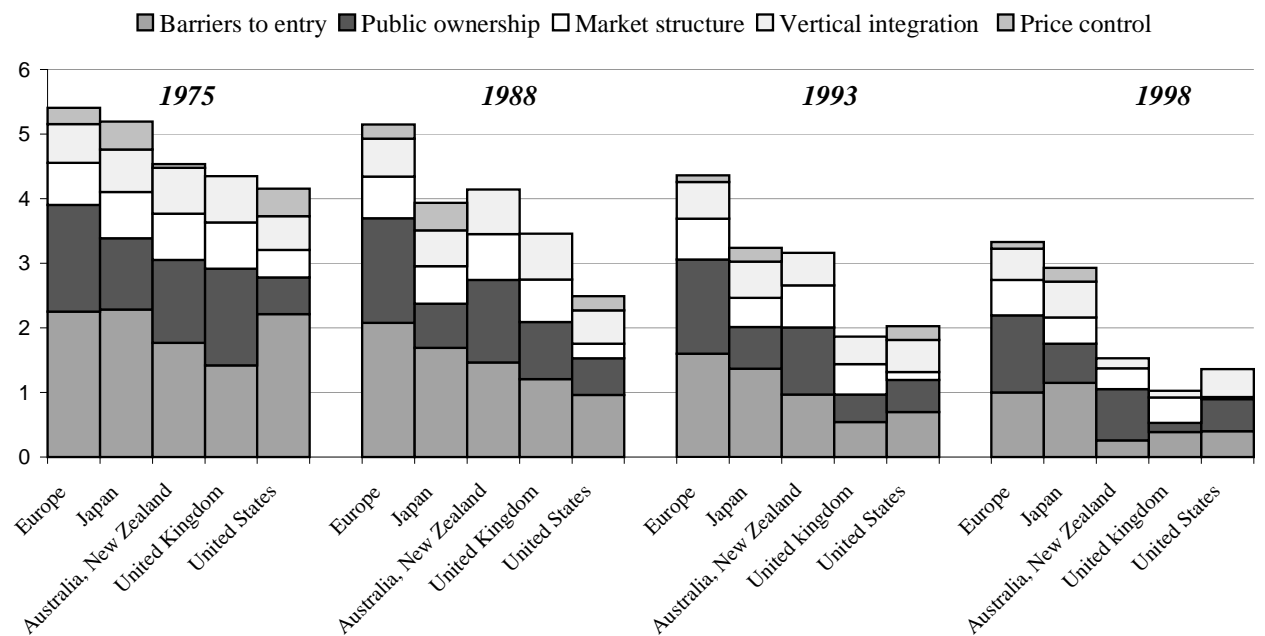

1. See annex for details.

2. Authors' calculations based on UNCTAD data. Aggregation of 2-digit tariffs with sectoral value-added weights.

2. Simple average of indicators for : gas and electricity supply, postal services, telecoms, air transport, railways, road freight. Depending on the industry the indicators cover : barriers to entry, public ownership, market structure, vertical integration and price controls. Europe data are weighted average (1995 GDP PPPs) of Austria, Belgium, Denmark, Finland, Germany, Greece, Ireland, Italy, Netherlands, Norway, Portugal, Spain, Sweden and Switzerland data. Source: See Annex. 
38. Regulatory reform has been deepest in non-manufacturing where, partly due to strong economies of scale and pervasive market failures, markets were most restricted by regulations concerning entry, prices and supply. Due to the scarce exposure to trade of these markets, domestic regulatory reform was the main policy tool for stepping up competitive pressures where competition was deemed viable. At the same time, the significant role played by non-manufacturing public enterprises in most countries highlighted governance problems and regulatory failures associated with public control and led to widespread privatisation. Figure 3 (Panel C) reports the evolution of the summary indicator of regulatory reform (ranging from 0 to 6 from most to least competitive) computed as the simple average of industry-level regulatory indicators for utilities, telecommunications and transportation industries. ${ }^{33}$ The indicator suggests that regulation in these industries was tight in all OECD countries in the 1970s, though more so in Europe and Japan. It is also apparent that the United States, the United Kingdom and Japan took the lead in regulatory reform during the 1980s, followed by Australia/New Zealand and, to a lesser extent, Europe in the following decade. By the end of the 1990s, common-law countries were clearly ahead of Europe and Japan in removing legal and structural barriers to entry and making market structure more competitive.

39. As a result of differences in initial conditions and the extent of regulatory reforms, the policy environment of OECD countries still differed a lot at the end of the 1990s both in specific nonmanufacturing industries and economy-wide. The two panels in Figure 4 capture these differences by means of our economy-wide and industry-level indicators of regulation (both increasing in the level of public ownership and restrictions to market mechanisms). As illustrated in Panel A, the industry-level environment was widely variable both within and across countries. ${ }^{34}$ Even in the "liberal" group, including most common-law and Nordic countries, a relatively restrictive environment could be found in some industries (e.g. retail distribution in the United Kingdom and Finland) and, conversely, countries in the "regulated" group, including some central and Southern-European countries, had a liberal environment in some industries (e.g. retail distribution in Switzerland and business activities in Greece). Indicators for nonmanufacturing industries often omit barriers to trade and administrative regulations. Once these, as well as other economy-wide regulatory areas (e.g. antitrust exemptions for public enterprises), are considered (Panel B), common-law countries continue to stand out for their liberal environment, now including Ireland, which benefits from relatively light barriers to trade and economy-wide regulations (e.g. administrative burdens), while at the other end the most regulated countries appear to be Italy, Greece, Norway and France. ${ }^{35}$ Since, with few exceptions (Norway and Canada) barriers to international trade and investment are very homogeneous across countries, most of the cross-country variance originates from differences in administrative and economic regulations (where the latter are defined to include both state control and barriers to entrepreneurship).

33 It should be stressed that important domestic reforms were also made in competitive industries such as retail distribution and financial services, but historical data are lacking for most OECD countries.

34 For illustrative purposes, countries are ranked according to the deviation of the average indicator across industries from the corresponding OECD average.

35 Some of these countries have implemented further privatisation and regulatory reforms since 1998. For instance, for Greece see OECD (2001d); and, for Italy, see OECD (2001e) and Nicoletti (2002). 
Figure 4. Regulatory environment in $\mathbf{1 9 9 8}^{1}$

Panel A. Regulation in non-manufacturing industries in $1998^{2}$

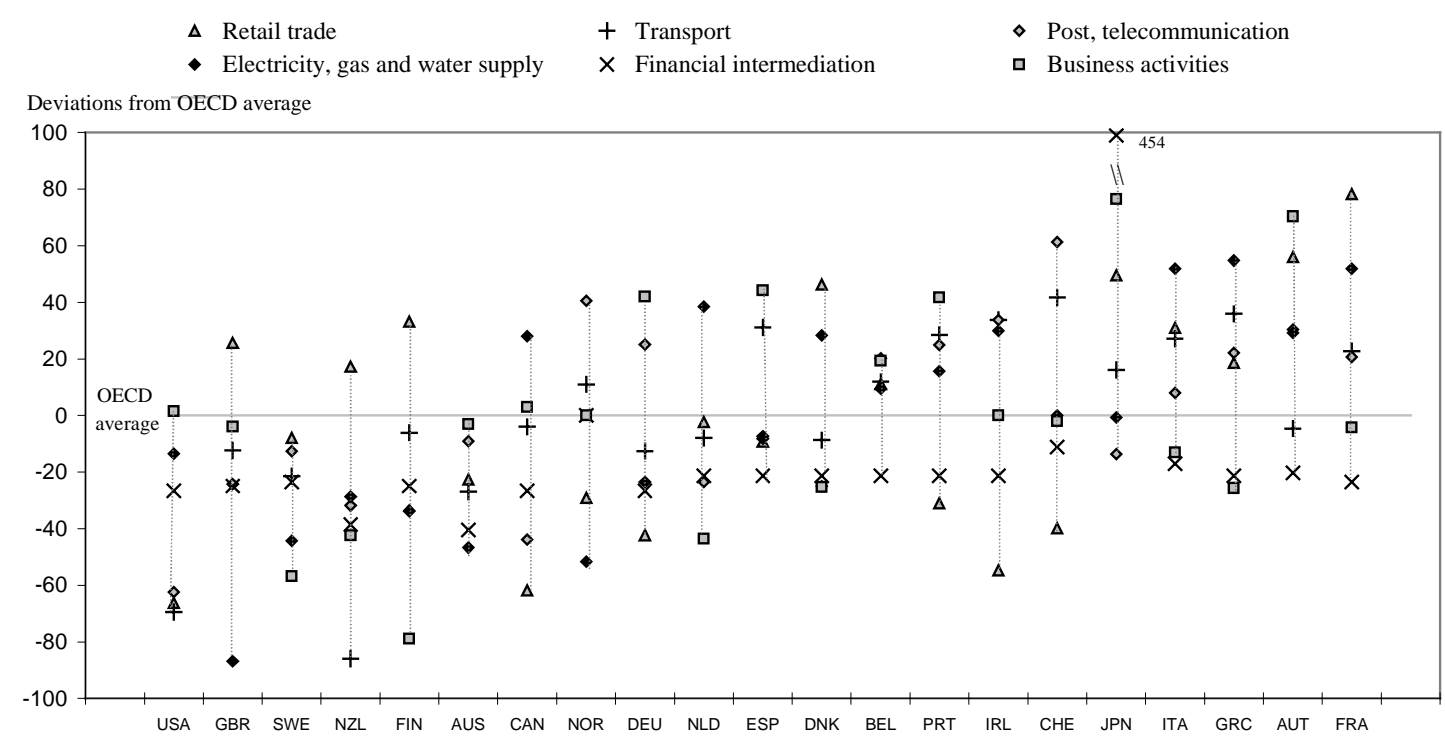

Panel B. Overall regulatory approaches by areas ${ }^{1}$

0-6 indicator from least to most restrictive

$\square$ Barriers to trade3 $\square$ Administrative regulation $\square$ Economic regulation4

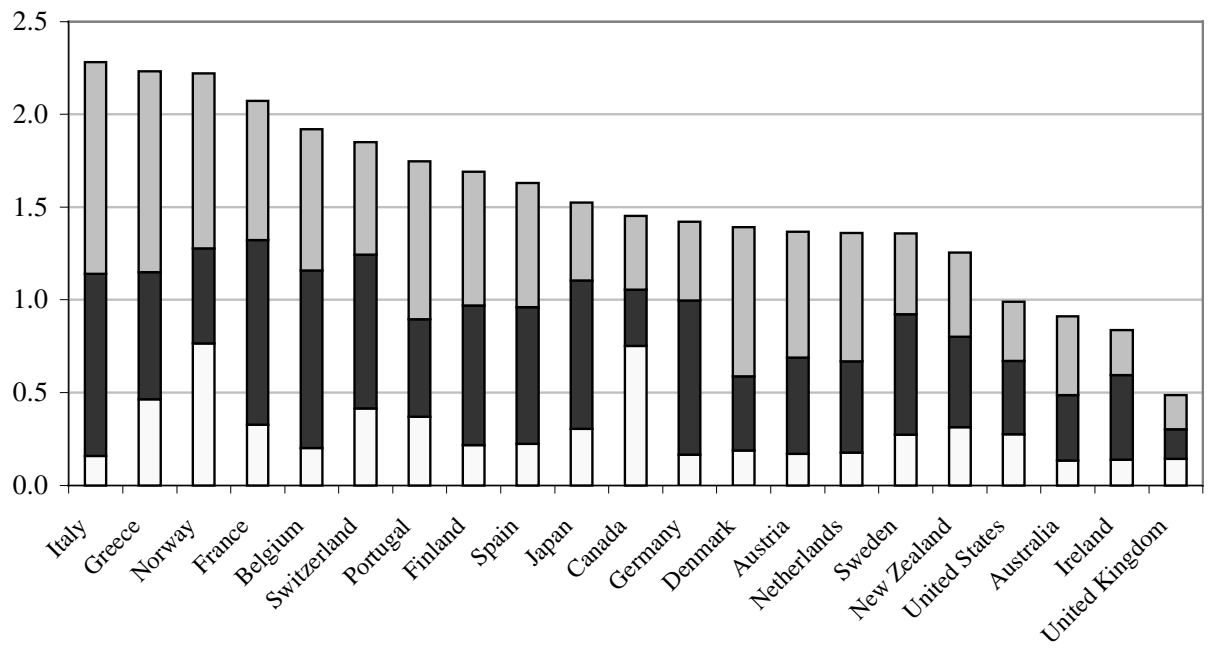

1. See annex for details.

2. Depending on the industry, the indicators cover public ownership, barriers to entry, price control, restrictions to business

operation, administrative burdens, market structure and vertical integration. Indicators are increasing with restrictions to competition.

3. Includes trade and FDI restrictions.

4. Includes barriers to competition and state control.

Source : See Annex. 


\subsection{Robustness of the findings}

40. To what extent do the patterns highlighted in Figures 3-4 reflect actual developments and differences among OECD countries? One way to check the robustness of our findings is to compare them with alternative indicators that broadly address the same phenomena using different approaches. This comparison can be done for the economy-wide regulatory environment, for which two alternative indicators have been recently proposed by Pryor (2002) and Kaufman et al. (1999). ${ }^{36}$ These indicators refer to the same period (1997/98) and cover roughly the same ground (state control and competitive pressures). Comparing the country rankings for our indicator with those implied by the two other indicators, the bivariate correlations range from 55 to 67 per cent and are significant at conventional levels (see appendix for details). These correlations are all the more reassuring in view of the "subjective" nature of the alternative indicators, which are mostly based on data originating from business surveys. The indicators are likely, therefore, to give actual enforcement a heavier weight than the formal framework. This may explain differences in the assessment of individual countries, such as the United States (which suffers from so-called "adversarial legalism" in Pryor's ranking) or Switzerland (which is difficult to classify due to its peculiar federal structure). Despite these idiosyncrasies, the three indicators seem to point broadly to the same economic realities.

41. Another way to assess the robustness of our results is to check to what extent the patterns highlighted by our indicator are sensitive to changes in aggregation methods. To this end, we recomputed the economy-wide indicator as a simple average of its 17 basic sub-indices, instead of using our original set of weights (see above). The ranking of the countries remains largely unchanged and the correlation between the two overall indicators (as well as between the indicators for the main regulatory areas) is over 90 per cent. Finally, it should be noted that, because overall indicators result from the aggregation of a large number of regulatory items, errors in measuring individual items are likely to have little impact on overall country rankings.

42. On the whole, these considerations suggest that changes in coverage, data collection methods and aggregation techniques and (a reasonable amount of) measurement errors are not likely to affect significantly the regulatory patterns presented in this paper. Of course, the ultimate check for the economic relevance of the patterns highlighted by the indicators in Figures 3-4 is their ability to contribute to explain the observed variation in different economic outcomes, including multi-factor productivity developments across countries. This is a task that will be taken up in the next sections of this paper.

\section{Empirical evidence}

\subsection{The basic MFP model}

43. Our empirical analysis is centred on a multi-factor productivity equation specified in order to account for the possible role of country and industry-specific factors. Denote countries by $i=1, \ldots \ldots, \mathrm{N}$, and industries by $j=1, \ldots . \mathrm{J}$. Value added in each industry at time $t$ is produced with labour (total hours worked, $H$ ) and physical capital $(K)$ according to a standard neo-classical production technology:

$$
Y_{i j t}=A_{i j t} \cdot F_{j}\left(H_{i j t}, K_{i j t}\right)
$$


where $F_{j}(\cdot)$ is assumed to be homogeneous of degree one and exhibits decreasing returns to the accumulation of each factor of production; and $A_{i j t}$ is an index of technological efficiency or multi-factor productivity (MFP).

44. We extend the conventional endogenous growth model-in which MFP is generally expressed as a function of knowledge and a residual set of influences (Aghion and Howitt, 1998) -- by assuming that, within each industry, the level of efficiency depends on country and industry characteristics as well as technological and organisational transfer from the technology-leader country $(i=L)$. This implies that MFP growth in the frontier country leads to faster MFP growth in follower countries by widening the production possibility set. We assume that, in each industry, a country's distance from the technological leader measures the scope for technological transfer. The leader country is defined as the country with the highest level of ${ }_{37}$ MFP. Hence, multi-factor productivity growth for a given industry $j$ of country $i$ can be modelled as follows:

$$
\Delta \ln A_{i j t}=\delta_{i j t} \Delta \ln A_{L j t}-\sigma_{i j t} \ln \left(A_{i} / A_{L}\right)_{j t-1}+\varepsilon_{i j t}
$$

where $\delta_{i j t}$ captures the instantaneous effect of changes in growth of the leader country; $\sigma_{i j t}$ indicates the pace of technological transfer; $\ln \left(A_{i} / A_{L}\right)_{j t-1}$ is the technology gap between country $i$ and the technology leader and $\varepsilon_{i j t}$ includes all other influences on MFP growth, including those related to differences in regulations across countries and industries (see below).

From the discussion in the previous sections, we also assume that certain regulations in the product market, by creating entry barriers or hindering competition amongst incumbents, may reduce opportunities and incentives for the adoption of the leading technologies. A linear formulation of the link between regulation (PMR) and the rate of technology transfer in non-frontier countries can be as follows:

$$
\sigma_{i j t}=\sigma_{1 i j t}+\sigma_{2 i j t} P M R_{i j t-1}
$$

Substituting [3] into [2] generates the following specification:

$$
\Delta \ln A_{i j t}=\delta_{i j t} \Delta \ln A_{L j t}-\sigma_{1 j i t} \ln \left(A_{i} / A_{L}\right)_{j t-1}-\sigma_{2 i j t} P M R_{i j t-1} \cdot \ln \left(A_{i} / A_{L}\right)_{j t-1}+\mathcal{E}_{i j t}
$$

In deriving a specification of the MFP equation that can be estimated empirically, it is important to notice that equation [4] can be seen as an error correction equation derived from a first-order autoregressive distributed-lag specification in which the MFP level in each country/industry is co-integrated with that of the leader, i.e.:

$$
\ln M F P_{i j t}=\beta_{1 j} \ln M F P_{i j t-1}+\beta_{2 j} \ln M F P_{L j t}+\beta_{3 j} \ln M F P_{L j t-1}+\omega_{i j t}
$$

Under the assumption of long-run homogeneity $\left(1-\beta_{1 \mathrm{j}}=\beta_{2 \mathrm{j}}+\beta_{3 \mathrm{j}}\right)$ and rearranging equation [5] yields:

$$
\Delta \ln M F P_{i j t}=\beta_{2 j} \Delta \ln M F P_{L j t}-\left(1-\beta_{1 j}\right) R M F P_{i j t-1}+\omega_{i j t}
$$

37 See Scarpetta and Tressel (2002a) for more details on this productivity model as well as Griffith et al. (2000) and de la Fuente and Doménech (2001) for similar specifications. 
where: $R M F P_{i t t-1} \ln \left(M F P_{i j-1} / M F P_{F j t-1}\right)$

Equation [6] is equivalent to equation [4] above, where the coefficient on relative MFP is allowed to be a function of regulations. In addition, we have imposed that the coefficient on MFP growth in the country leader $\left(\beta_{2 j}\right)$ and that on the technology transfer $\left(1-\beta_{l j}\right)$ vary only across industries (in the empirical analysis we further restrict them to vary only between manufacturing and services).

Moreover, the error term in equations [5] and [6] can be decomposed into a vector of covariates $\left(V_{i j t}\right)$, including structural features (e.g. human capital) and regulatory policies, potentially affecting the level of MFP; unobserved country and industry effects $\left(f_{i}, g_{j}\right.$, respectively); world macroeconomic shocks $\left(d_{t}\right)$ and a serially uncorrelated error term. $\left(\eta_{i j t}\right)$ :

$$
\omega_{i j t}=\sum_{k} \gamma_{k} V_{k i j t-1}+f_{i}+g_{j}+d_{t}+\eta_{i j t}
$$

From equation [6] it is clear that the coefficient of the MFP gap term measures the speed of (conditional) convergence to the long-run steady state level of MFP. Moreover, in the presence of technological convergence, the technological distance between each country/industry and the leader converges to a constant value. This implies that the vector of covariates as well as the country and industry fixed effects translate only into differences in MFP levels, and not into permanent differences in growth rates of MFP.

\subsection{Data and empirical implementation}

45. We estimated the productivity model [6]-[7] by means of a fixed-effect estimator including country and industry effects and time dummies. The basic productivity regression includes as explanatory variables MFP growth in the leader country, the technology gap variable and a proxy for human capital. This regression is progressively extended to include various indicators of product market regulation and privatisation. In all regressions, we tested whether regulatory policies had an impact on long-run productivity levels, both directly and through their influence on the rate of technological catch up. We also consistently tested for differences in the estimated coefficients between manufacturing and service industries. ${ }^{38}$ To interpret the results, it should be noted that there is a mismatch between the quality of our productivity and regulation data. The best productivity data are for manufacturing, where MFP estimates suffer less from mis-measurement problems, while the most complete regulatory data are for the service sector. The empirical analysis covers 23 two-digit industries in manufacturing and business services in 18 OECD countries over the period 1984-1998. ${ }^{39}$

38 The speed of technological catch-up may differ between manufacturing and services due to: $i$ ) the different technological level in the two broadly-defined sectors, and the role played by innovation and adoption of new technologies; ii) differences in manufacturing and service workers' skills (a complementary input to new technologies); and iii) a different exposure to trade.

39 The countries are: Australia, Austria, Belgium, Canada, Denmark, Spain, Finland, France, (western) Germany, Greece, Italy, Japan, Netherlands, Norway, Portugal, Sweden, United Kingdom and United States. The industry breakdown is as follows: 17 manufacturing industries and 6 business services industries. Agriculture, mining and quarrying, construction, electricity gas and water as well as community and personal services have been excluded from the analysis either because of particularly poor quality of the MFP data or because data on regulations were lacking. 


\subsubsection{Multi-factor productivity data}

46. The main source of the industry-level productivity data is the OECD STAN database (edition 2001) that contains internationally comparable data on value added, employment and capital stocks. The labour input variable is based on industry-level data on employment and on average hours worked, the latter obtained from both OECD and non-OECD sources. To capture the influence on MFP of differences in the quality of the labour input, we also considered different levels of human capital across countries, industries and time. The appendix provides further details on these calculations.

The measure of MFP growth was computed as follows (see also Box 1):

$$
\Delta M F P_{i j t}=\Delta y_{i j t}-\alpha_{i j t} \cdot \Delta l_{i j t}-\left(1-\alpha_{i j t}\right) \cdot \Delta k_{i j t}
$$

where $y, l$ and $k$ are respectively the logarithms of real value-added, total hours worked and real capital stock. Under perfect competition, $\alpha$ in equation [8] can be proxied by the share of labour compensation in total costs. ${ }^{40}$

Following Caves et al. (1982) we used the following (multilateral productivity) index as a measure of the MFP level:

$$
\operatorname{MFP}_{i j t}=\frac{Y_{i j t}}{\bar{Y}_{j t}} \cdot\left(\frac{\bar{L}_{j t}}{L_{i j t}}\right)^{\alpha_{i j t}} \cdot\left(\frac{\bar{K}_{j t}}{K_{i j t}}\right)^{1-\alpha_{i j t}}
$$

where a bar denotes a geometric average over all the countries for a given industry $j$ and year $t$. The technological frontier is defined as the highest value of MFP level relative to the geometric average in each industry $j$ in the year $t$, and the technological gap is the difference between the level of MFP and the frontier level in each industry and year.

The calculations of MFP levels required the use of comparative product price levels across countries in order to convert the value of production to common units, while taking into account differences in the purchasing power of each country's currency. Ideally, comparative product prices should be measured at the producer level, but survey data on production prices are usually available only for a few countries and for even fewer

40 In a related paper Scarpetta and Tressel (2002a) show that correcting the labour share, and thus the estimated MFP growth rate, for the presence of mark-ups of prices over marginal costs has little repercussion on the baseline estimates of the MFP equation. The labour share, however, is volatile, reflecting short-run fluctuations in demand conditions and possibly the fact that wages are not negotiated on an annual basis. In order to minimise these short-run fluctuations, we used a measure of the labour share from Scarpetta and Tressel $(2002 a)$. They regressed the labour share on country-industry specific fixed effects and on the logarithm of capital-labour ratio. Fixed effects account for unobserved factors influencing the technology used (such as endowments, available technologies, institutional factors). Next, they used as a country/sectorspecific measure of the labour share the fitted value from this equation, which accounts for country-industry fixed components plus variations due to changes in the capital intensity. 
products. Thus, we used estimates of industry-specific expenditure PPPs. They offer a better basis for comparing productivity levels than standard aggregate GDP PPPs (as in Bernard and Jones, 1996a,b). ${ }^{41}$

\subsubsection{Regulatory indicators}

47. To check the influence of product market policies on MFP we extended the basic productivity regression including various proxies for public ownership and regulation. A problematic aspect of our regulation data is that they involve three different levels of regulatory detail each covering a different dimension of regulation (cross-country, cross-industry, time-series). The economy-wide indicators have the largest coverage in terms of regulatory detail, but have no time dimension. The industry-specific indicators have a large industry coverage but focus on a restricted set of regulations and have no time dimension. Finally, indicators for which we have a full time-series have less regulatory detail and cover only trade barriers in manufacturing and industry-level regulation in a subset of the non-manufacturing industries. In the empirical analysis we tried to exploit all the information available in the data by combining indicators covering different dimensions of regulation. Moreover, to minimise spuriousness due to different coverage of regulatory detail across industries, throughout the empirical analysis we focus mostly on patterns and developments in barriers to entry and public ownership.

48. Accordingly, we estimated three versions of the productivity model, which differ only by the definition of the indicators of regulation and public ownership included among the covariates (Table 4 provides the precise definitions):

- In the first set of regressions, we concentrated on overall privatisation and economy-wide regulation in 1998, proxied by the summary indicator as well as by its main components, state control and barriers to entrepreneurship. The implicit assumption in these regressions is that the relative position of each country's regulatory environment (captured by the cross-country indicator of regulation) changes slowly and, therefore, end-of-period values are representative of the cross-country patterns of regulation over the sample period. To relax this latter assumption and account for both the cross-country and time-series dimension of regulation, we also combined the 1998 economy-wide indicator of regulation with the time-series indicator of entry liberalisation that summarises reform trends in seven non-manufacturing industries. The assumption here is that reforms in non-manufacturing are a good proxy for economy-wide regulatory trends.

- In the second set of regressions, we distinguish between regulation in manufacturing and services. To this end, we use a time-series indicator of entry liberalisation that stacks entry liberalisation in services and entry liberalisation in manufacturing, the latter defined as the combination of changes in both trade and domestic non-manufacturing regulations. The underlying assumption is that entry liberalisation in the non-manufacturing sector also has an impact on manufacturing because it affects the cost of important inputs into manufacturing output. ${ }^{42}$ In these regressions, we also try to account for different patterns of privatisation in

41 The potential problems arising from using aggregate PPPs are discussed in Harrigan (1999) and Sørensen (2001). In a sensitivity analysis of the baseline MFP equation, Scarpetta and Tressel (2002a) also used aggregate GDP PPPs and found no significant differences in the key results.

Of course, the entry liberalisation indicator excludes changes in public ownership, which are accounted for by the privatisation indicator. The coverage of trade liberalisation in manufacturing (captured by changes in tariff and non-tariff barriers to trade) provides an industry dimension to the indicator. 
manufacturing and services. However, due to the lack of sector-specific data, privatisation in manufacturing was proxied by economy-wide privatisation trends. ${ }^{4}$

- In the third set of regressions, we supplement the indicators of overall privatisation and entry liberalisation with the industry-level indicators of barriers to entry. In manufacturing industries, we defined these indicators to include only (the period average of) industry-specific non-tariff barriers to trade and economy-wide administrative burdens, assuming that in the OECD countries covered in our sample, domestic legal barriers to entry are insignificant. ${ }^{44}$ In service industries, barriers to entry in 1998 included industry-specific legal barriers and vertical integration (when applicable), as well as economy-wide (and industry-specific when available) administrative burdens.

Table 4. Variables used in regressions ${ }^{1}$

\begin{tabular}{|c|c|c|}
\hline Variable $^{2}$ & Definition & Sample \\
\hline$\Delta$ MFP Leader $_{i j t}$ & Growth rate in multifactor productivity of leader country & $\begin{array}{l}17 \text { manufacturing and } 6 \text { non-manufacturing } \\
\text { industries, } 18 \text { OECD countries, } 1984-1998\end{array}$ \\
\hline Technology Gap $_{i j t}$ & Log difference of MFP level to MFP level of leader country & $\begin{array}{l}17 \text { manufacturing and } 6 \text { non-manufacturing } \\
\text { industries, } 18 \text { OECD countries, } 1984-1998\end{array}$ \\
\hline Human Capital $_{i j t}$ & Average of employment by skill levels weighted with relative wages by skill levels & $\begin{array}{l}17 \text { manufacturing and } 6 \text { non-manufacturing } \\
\text { industries, } 18 \text { OECD countries, } 1984-1998\end{array}$ \\
\hline Regulation $_{i}$ & $\begin{array}{l}\text { Economy-wide indicator of general-purpose and industry-specific regulations. } \\
\text { Increases with restrictions to market mechanisms. }\end{array}$ & 18 OECD countries, 1998 \\
\hline Regulation (state control) $i$ & $\begin{array}{l}\text { Economy-wide indicator of general-purpose and industry-specific regulations in the } \\
\text { area of state control. Increases with restrictions to market mechanisms. }\end{array}$ & 18 OECD countries, 1998 \\
\hline Regulation (barriers to entrep.) $i$ & $\begin{array}{l}\text { Economy-wide indicator of general-purpose and industry-specific regulations in the } \\
\text { area of barriers to entrepreneurship. Increases with restrictions to market } \\
\text { mechanisms. }\end{array}$ & 18 OECD countries, 1998 \\
\hline Entry Liberalisation $(S E R V)_{\text {it }}$ & $\begin{array}{l}\text { Summary indicator of entry liberalisation in } 7 \text { non-manufacturing industries. } \\
\text { Measures the change in barriers to entry. }\end{array}$ & 18 OECD countries, $1984-1998$ \\
\hline Entry Liberalisation $(M A N)_{i t}$ & $\begin{array}{l}\text { Summary indicator of trade liberalisation in } 17 \text { manufacturing industries. Measures } \\
\text { the change in tariff and non-tariff barriers to trade. }\end{array}$ & 18 OECD countries, $1984-1998$ \\
\hline Regulation (time-varying) ${ }_{\text {it }}$ & $\begin{array}{l}\text { Interaction between the indicator of Regulation and the indicator of Entry liberalisation } \\
(S E R V) \text {. Increases with restrictions to market mechanisms. }\end{array}$ & 18 OECD countries, $1984-1998$ \\
\hline Overall Privatisation $_{i t}$ & Economy-wide indicator of privatisation. Measures the change in public ownership. & 18 OECD countries, $1984-1998$ \\
\hline Entry Liberalisation $_{i j t}$ & $\begin{array}{l}\text { Indicator of entry liberalisation in the manufacturing and non-manufacturing aggregates. } \\
\text { Combines Entry Liberalisation (MAN) with Entry Liberalisation (SERV). Measures the } \\
\text { change in barriers to trade and barriers to entry. }\end{array}$ & $\begin{array}{l}\text { Manufacturing and non-manufacturing aggregates, } \\
18 \text { OECD countries, } 1984-1998\end{array}$ \\
\hline Privatisation $_{i j t}$ & $\begin{array}{l}\text { Indicator of privatisation in the manufacturing and non-manufacturing aggregates. Stacks } \\
\text { the indicator of Overall Privatisation in manufacturing and a summary indicator of } \\
\text { privatisation in } 7 \text { non-manufacturing industries. Measures the change in public ownership. }\end{array}$ & $\begin{array}{l}\text { Manufacturing and non-manufacturing aggregates, } \\
18 \text { OECD countries, 1984-1998 }\end{array}$ \\
\hline Barriers to Entry ${ }_{i j}$ & $\begin{array}{l}\text { Industry-level indicator of barriers to entry. Stacks the industry-level indicators of } \\
\text { barriers to trade in manufacturing and the industry-level indicators of barriers to } \\
\text { entry in non-manufacturing. Increases with barriers to entry. }\end{array}$ & $\begin{array}{l}17 \text { manufacturing and } 6 \text { non-manufacturing } \\
\text { industries, } 18 \text { OECD countries, } 1998\end{array}$ \\
\hline
\end{tabular}

1. See Section 3 and Appendix for further details on definitions and coverage

2. i stands for country; j stands for industry; t stands for time

43 Information on the sectoral distribution of public enterprises also including manufacturing is available only for some EU countries.

44 Drawing on the OECD International Regulation Database, Nicoletti et al. (1999) show that such barriers are virtually absent in the core OECD countries covered by our sample. 


\subsection{Empirical results}

49. Table 5 presents different specifications of a baseline equation in which MFP growth is regressed only on the industry leader, the technology-gap variable and human capital. From the discussion above, all specifications control for country and industry fixed effects. Moreover, all equations include time dummies to control for common aggregate shocks that affect MFP in all countries. ${ }^{45}$ As shown in the first column of the table, the Cook-Weisberg test clearly signals problems of heteroskedasticity and, thus, in all subsequent regressions we present robust standard errors. Moreover, our cross-country time-series regressions can be quite sensitive to the presence of a few outliers and influential observations in the sample usually due to measurement errors or specific omitted variables. In particular, we identify 64 outlier observations in the sample-set used in equation 1 , which were removed from the sample used in all other equations. ${ }^{46}$ As a further step in our sensitivity analysis we also checked for the presence of specific industries in given countries that, because of different technological features or simply measurement errors, influence significantly the overall results. On the whole, the results presented below are robust to these changes in the sample (see the appendix for more details).

50. The technology-gap variable enters negatively and is significant at conventional levels in all specifications, suggesting that, within each industry, countries that are further behind the technological frontier experience higher rates of productivity growth. As stressed above, we also allowed the coefficients of the productivity leader and the technology gap to vary between manufacturing and service industries. Consistent with some previous results (e.g. Bernard and Jones, 1996a,b), there is evidence in the data of a more rapid technological catch-up in service industries as compared with manufacturing. ${ }^{47}$ This is particularly the case for the short-term technological passthrough (i.e. the coefficient of the leader country) that is not significant in manufacturing industries, but also over the longer run as indicated by the coefficient of the technology gap variable. ${ }^{48}$ The results also suggest a positive effect of human capital on MFP, as would be expected.

45 The standard F-tests for the presence of country, industry and time dummies strongly support (at the 1 per cent level) their inclusion in the productivity equation. In the sensitivity analysis, we also considered country-specific time trends. However, none of the estimated coefficients of the time trend was statistically significant (even at the 10 per cent level) and, thus, these trend variables were not included in the preferred specifications.

46 The identification of outlier observations is based on the studentised residuals and the leverage points. The former are obtained by considering a mean-shift outlier model in which the basic equation is augmented by a dummy variable that has the $i$-th element equal to one and all other elements zero. The studentised residual is the t-statistics of the dummy variable. The leverage point is identified by the diagonal elements of the leastsquared projection matrix, also called the hat matrix. It proxies the distance between the $i$-th observation and the centre of the data (see Belsey et al., 1980; and Chatterjee and Hadi, 1988).

47 The Wald tests for the equality of the coefficients (on both MFP growth in the leader country and the technology gap) between manufacturing industries and services are rejected at the 1 and 5 per cent level, respectively.

Using cross-section data Bernard and Jones $(1996 a, b)$ found evidence of convergence in the service sector but not in manufacturing. Garcia Pascual and Westermann (2001), using more disaggregated manufacturing industries (along the lines of this study) for some OECD countries, found evidence of convergence in manufacturing. 
Table 5. MFP regressions: selection of baseline specification

\begin{tabular}{|c|c|c|c|c|}
\hline & 1 & 2 & 3 & 4 \\
\hline$\overline{\text { Constant }}$ & $\begin{array}{r}-0.02 \\
(0.02) \\
\end{array}$ & $\begin{array}{l}-0.02 \text { * } \\
(0.01)\end{array}$ & $\begin{array}{l}-0.08 * \\
(0.04)\end{array}$ & $\begin{array}{l}-0.09^{* *} \\
(0.04)\end{array}$ \\
\hline$\Delta$ MFP Leader ${ }_{j t}$ & $\begin{array}{r}-0.01 \\
(0.01)\end{array}$ & $\begin{array}{r}-0.01 \\
(0.01)\end{array}$ & $\begin{array}{r}-0.01 \\
(0.01)\end{array}$ & \\
\hline Technology gap $_{\mathrm{ij} \mathrm{t}-1}$ & $\begin{array}{l}-0.06^{* * *} \\
(0.01)\end{array}$ & $\begin{array}{l}-0.03^{* \star *} \\
(0.004)\end{array}$ & $\begin{array}{l}-0.03 \text { *** } \\
(0.004)\end{array}$ & \\
\hline Human capital $_{i j t}$ & & & $\begin{array}{c}0.12 \\
(0.07)\end{array}$ & $\begin{array}{c}0.14 \\
(0.07)\end{array}$ \\
\hline$\Delta$ MFP Leader ${ }_{j t}($ MAN) & & & & $\begin{array}{r}-0.01 \\
(0.01)\end{array}$ \\
\hline$\Delta$ MFP Leader ${ }_{j t}(\mathrm{SERV})$ & & & & $\begin{array}{l}0.08^{* * *} \\
(0.02)\end{array}$ \\
\hline Technology gap ${ }_{\mathrm{ijt}-1}(\mathrm{MAN})$ & & & & $\begin{array}{l}-0.03^{* * *} \\
(0.004)^{*}\end{array}$ \\
\hline Technology gap $_{\mathrm{ijt} t-1}(\mathrm{SERV})$ & & & & $\begin{array}{l}-0.05^{* * *} \\
(0.01)^{2}\end{array}$ \\
\hline Number of observations & 3250 & 3186 & 3101 & 3101 \\
\hline $\begin{array}{l}\text { Heteroskedasticity } \\
\text { Reset }^{2}\end{array}$ & $\begin{array}{r}1368.04^{* * *} \\
83.15^{* * *}\end{array}$ & 0.81 & 0.35 & 0.37 \\
\hline
\end{tabular}

${ }^{* \star \star}$ denotes significance at the $1 \%$ level; ${ }^{* *}$ at $5 \%$ level; ${ }^{*}$ at $10 \%$ level.

Robust standard errors (from eq.2) in parentheses.

Sample are adjusted for outliers from equation 2 onwards. See main text.

All equations include country, industry and time dummies.

1. Cook and Weisberg test for heteroskedasticity.

2. Ramsey's omitted-variable test: F-test on the joint significance of the additional terms in a model augmented with the second, third and fourth powers of the predicted values of the original model.

51. In Table 6, we extended the analysis to check the influence of economy-wide privatisation patterns and product market regulations, looking at both their direct impact and their indirect influence through the rate of technological catch up. We consider both the summary indicator of regulation and two of its main components, the indicator of state control and that of barriers to entrepreneurship. Due to the lack of the time dimension for these indicators, their inclusion in the MFP equation comes at the cost of dropping the country dummies. Since the omission of unobservable country-specific influences may misleadingly provide explanatory power to the regulatory indicators, we use the standard RESET test to assess the extent of a possible mis-specification of the equation. ${ }^{49}$ In any event, we adjusted the standard errors and variancecovariance matrix of the estimators for cluster level effects on country-industry using the procedure suggested by Moulton (1986).

49 The RESET test is the Ramsey omitted variable regression test. 
52. The results in Table 6 suggest that economy-wide product market regulations that curb competition and private governance have a negative effect on productivity, mainly by slowing down technological catch-up (as suggested by the positive coefficient on the interaction term). Both the overall indicator of the stringency of regulation and its component measuring the extent of state control in the business sector have statistically significant coefficients when they are interacted with the technological gap. ${ }^{50}$ The effect of barriers to entrepreneurship on productivity (not shown in the table) is also negative via the catch-up channel, but it is not significant at conventional levels. The coefficient of the privatisation variable is generally positive and significant at conventional levels, suggesting that countries in which privatisation was more extensive benefited from persistent productivity gains. Of course, since the scope for privatisation is bound by the size of the public enterprise sector, productivity gains via this channel cannot be reproduced indefinitely.

53. The omission of country dummies, which was necessary to test the effects of economy-wide regulations, introduces a possible mis-specification bias as indicated by the fact that, relative to the estimates in Table 4, the RESET tests are somewhat larger and, in addition, the coefficient of human capital becomes insignificant. ${ }^{51}$ To tackle this potential source of bias we need to account for the evolution of regulation over time and for the patterns of regulation across industries and re-introduce the country-specific effects. Since data along these two dimensions are incomplete (see above), we proceed in several steps using different proxies. In the last column of Table 6, we considered an indicator of the stringency of product market regulation that combines the 1998 indicator of economy-wide regulation with the time-varying indicator of entry restrictions in non-manufacturing industries. ${ }^{52}$ The results suggest that by taking the dynamics of regulation into account, the direct effect on productivity dominates that stemming from the interaction with the technology gap.

50 These results are broadly consistent with those of Blundell et al. (1995, 1999) and Nickell (1996) and Cheung and Garcia Pascual (2001), although these papers use direct proxies for the degree of product market competition which are subject to an endogeneity problem.

51 One potential influence captured by the (omitted) country-specific effects is related to labour adjustment costs, which can be proxied by the indicator of the strictness of employment protection legislation. In a sensitivity analysis we have also included the EPL indicator in the productivity equation but this does not alter the sign or statistical significance of the estimated coefficients of the product market regulatory indicators. See also Scarpetta and Tressel (2002b).

52 Time-varying entry restrictions are defined as the negative of the indicator of entry liberalisation to avoid ambiguity in the interpretation of the combined indicator. 
Table 6. MFP regressions: The role of aggregate indicators of regulation and privatisation

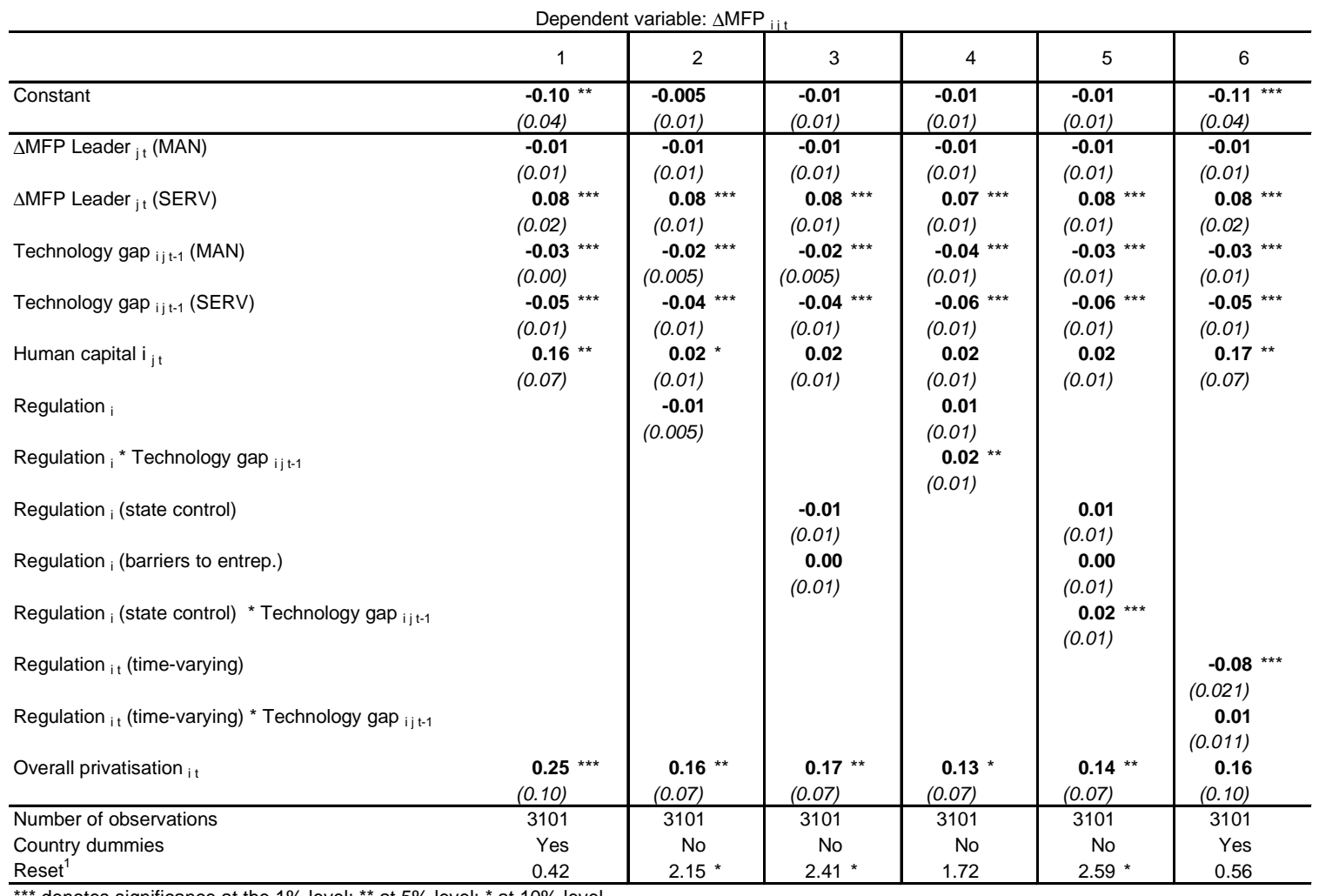

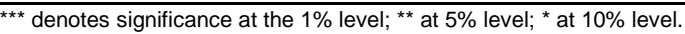

Robust standard errors in equation 1 and 6 ; adjusted standard errors for clustering in equations 2-5.

Samples are adjusted for outliers. See main text.

All equations include industry and time dummies.

Indicators of privatisation measure the change in public ownership and indicators of product market regulation are increasing in the

degree of restrictions imposed on market mechanisms.

1. Ramsey's omitted-variable test: F-test on the joint significance of the additional terms

in a model augmented with the second, third and fourth powers of the predicted values

of the original model.

54. Combining this latter result with those of the previous specifications, we are tempted to conclude that the long-run costs of anti-competitive regulation, in terms of foregone productivity improvements, are higher in countries that are further away from the technological frontier. This detrimental effect of strict product market regulations on productivity catch-up may result, for instance, from lower incentives for organisational and technological change in firms that are subject to state interference (e.g. price controls), and, in addition, a narrower scope for knowledge spillovers in markets where entry is restricted. At the same time, by increasing competitive pressures, entry liberalisation has a generalised effect on industry productivity in all countries, regardless of their position with respect to the technology frontier. ${ }^{53}$

55. As a second step in our assessment of product market regulations, while controlling for country-specific effects, we considered entry barriers and privatisation separately for manufacturing and for the service sector. The results presented in Table 7 tend to confirm the positive productivity effect of

53 For additional evidence of the productivity effects of entry liberalisation at the industry level, see Gönenc et al. (2001). 
privatisation. Similarly, the positive effect of entry liberalisation on productivity is consistent with the results previously obtained using the time-varying indicator of economy-wide regulation. However, the table shows that this effect is (weakly) significant only for manufacturing, suggesting the need to differentiate further the analysis across industries.

Table 7. MFP regressions: The role of regulations in manufacturing and services

\begin{tabular}{|c|c|c|c|}
\hline & 1 & 2 & 3 \\
\hline Constant & $\begin{array}{l}-0.09^{* *} \\
(0.04)\end{array}$ & $\begin{array}{l}-0.09^{\star *} \\
(0.04)\end{array}$ & $\begin{array}{l}-0.09^{* *} \\
(0.04)\end{array}$ \\
\hline$\Delta$ MFP Leader $_{\mathrm{jt}}(\mathrm{MAN})$ & $\begin{array}{r}-0.01 \\
(0.01)\end{array}$ & $\begin{array}{r}-0.01 \\
(0.01)\end{array}$ & $\begin{array}{r}-0.01 \\
(0.01)\end{array}$ \\
\hline$\Delta$ MFP Leader $_{\mathrm{jt}}(\mathrm{SERV})$ & $\begin{array}{l}0.08^{* * *} \\
(0.02)\end{array}$ & $\begin{array}{l}0.08 \\
(0.02)\end{array}$ & $\begin{array}{l}0.09^{* * *} \\
(0.02)\end{array}$ \\
\hline Technology gap i j t-1 (MAN) & $\begin{array}{l}-0.03 * * * \\
(0.00)\end{array}$ & $\begin{array}{l}-0.03^{* * *} \\
(0.01)\end{array}$ & $\begin{array}{l}-0.03^{* * *} \\
(0.01)\end{array}$ \\
\hline Technology gap i t t-1 $_{\text {(SERV) }}$ & $\begin{array}{l}-0.05^{* * *} \\
(0.01)\end{array}$ & $\begin{array}{l}-0.05 * * * \\
(0.02)\end{array}$ & $\begin{array}{l}-0.06^{* * *} \\
(0.02)\end{array}$ \\
\hline Human capital $_{\mathrm{ijt}}$ & $\begin{array}{l}0.15^{* *} \\
(0.07)\end{array}$ & $\begin{array}{l}0.15^{* *} \\
(0.07)\end{array}$ & $\begin{array}{l}0.15^{* *} \\
(0.07)\end{array}$ \\
\hline Entry liberalisation $_{\mathrm{it}}$ & $\begin{array}{r}-0.02 \\
(0.02)\end{array}$ & $\begin{array}{r}-0.02 \\
(0.02)\end{array}$ & \\
\hline Entry liberalisation $_{\mathrm{it}}$ * Technology gap ij t-1 & & $\begin{array}{r}0.01 \\
(0.02)\end{array}$ & \\
\hline Entry liberalisation $(\mathrm{MAN})_{\text {it }}$ & & & $\begin{array}{r}0.05 * \\
(0.02)\end{array}$ \\
\hline Entry liberalisation $(S E R V)_{\text {it }}$ & & & $\begin{array}{r}0.01 \\
(0.02)\end{array}$ \\
\hline 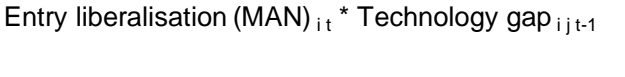 & & & $\begin{array}{l}0.001 \\
(0.02)\end{array}$ \\
\hline Entry liberalisation $(\mathrm{SERV})_{\mathrm{it}}{ }^{*}$ Technology gap $_{\mathrm{ij} \mathrm{t}-1}$ & & & $\begin{array}{r}-0.01 \\
(0.03)\end{array}$ \\
\hline Privatisation $_{\mathrm{ij} \mathrm{t}}$ & $\begin{array}{r}0.09 * \\
(0.05)\end{array}$ & $\begin{array}{r}0.09 * \\
(0.05)\end{array}$ & $\begin{array}{r}0.09 * * \\
(0.05)\end{array}$ \\
\hline $\begin{array}{l}\text { Number of observations } \\
\text { Reset }^{1}\end{array}$ & $\begin{array}{r}3101 \\
0.44\end{array}$ & $\begin{array}{r}3101 \\
0.43\end{array}$ & $\begin{array}{r}3101 \\
0.52\end{array}$ \\
\hline
\end{tabular}

*** denotes significance at the $1 \%$ level; ${ }^{* *}$ at $5 \%$ level; * at $10 \%$ level.

Robust standard errors.

Samples are adjusted for outliers. See main text.

All equations include country, industry and time dummies.

Indicators of privatisation measure the change in public ownership and indicators of entry liberalisation

measure the easing of restrictions imposed on marked mechanisms.

1. Ramsey's omitted-variable test: F-test on the joint significance of the additional terms

in a model augmented with the second, third and fourth powers of the predicted values

of the original model. 
Table 8. MFP regressions: The role of industry-specific regulations and regulatory reforms

Dependent variable: $\triangle \mathrm{MFP}_{\mathrm{ijt}}$

\begin{tabular}{|c|c|c|c|}
\hline & 1 & 2 & 3 \\
\hline Constant & $\begin{array}{l}-0.10^{* *} \\
(0.05)\end{array}$ & $\begin{array}{l}-0.09^{* *} \\
(0.05)\end{array}$ & $\begin{array}{l}-0.099^{* *} \\
(0.05)\end{array}$ \\
\hline$\Delta \mathrm{MFP}$ Leader $(\mathrm{MAN})_{\mathrm{jt}}$ & $\begin{array}{r}-0.01 \\
(0.01)\end{array}$ & $\begin{array}{r}-0.01 \\
(0.01)\end{array}$ & $\begin{array}{r}-0.01 \\
(0.01)\end{array}$ \\
\hline$\Delta$ MFP Leader (SERV) j t & $\begin{array}{c}0.08^{* * *} \\
(0.02)\end{array}$ & $\begin{array}{l}0.08^{* * *} \\
(0.02)\end{array}$ & $\begin{array}{l}0.08^{* * *} \\
(0.02)\end{array}$ \\
\hline Technology gap (MAN) ijt-1 & $\begin{array}{l}-0.04^{\star * *} \\
(0.01)\end{array}$ & $\begin{array}{l}-0.04^{* * *} \\
(0.01)\end{array}$ & $\begin{array}{l}-0.04^{\star * *} \\
(0.01)\end{array}$ \\
\hline Technology gap (SERV) i j t-1 & $\begin{array}{l}-0.06^{* * *} \\
(0.01)\end{array}$ & $\begin{array}{l}-0.05^{* * *} \\
(0.01)\end{array}$ & $\begin{array}{l}-0.06^{* * *} \\
(0.01)\end{array}$ \\
\hline Human capital $_{\mathrm{ijt}}$ & $\begin{array}{r}0.13 \text { * } \\
(0.08)\end{array}$ & $\begin{array}{c}0.14 \text { * } \\
(0.07)\end{array}$ & $\begin{array}{r}0.14 \text { * } \\
(0.08)\end{array}$ \\
\hline Barriers to entry $(\mathrm{MAN})_{\mathrm{ij}}$ & $\begin{array}{r}0.04 \\
(0.02)\end{array}$ & $\begin{array}{r}0.03 \\
(0.02)\end{array}$ & $\begin{array}{r}0.03 \\
(0.02)\end{array}$ \\
\hline Barriers to entry $(\mathrm{MAN})_{\mathrm{ij}}$ * Technology gap $\mathrm{ijt-1}$ & $\begin{array}{c}0.04 \text { * } \\
(0.02)\end{array}$ & $\begin{array}{c}0.04 \\
(0.02)\end{array}$ & $\begin{array}{c}0.04 \text { * } \\
(0.02)\end{array}$ \\
\hline Barriers to entry $(\mathrm{SERV})_{\mathrm{i} j}$ & $\begin{array}{r}0.04 \\
(0.02)\end{array}$ & $\begin{array}{c}0.04 \text { * } \\
(0.02)\end{array}$ & \\
\hline Barriers to entry (SERV) (non-comp) i j & & & $\begin{array}{r}0.04 \\
(0.03)\end{array}$ \\
\hline Barriers to entry (SERV) (comp) ${ }_{i j}$ & & & $\begin{array}{r}0.04 \\
(0.03)\end{array}$ \\
\hline Barriers to entry $(\mathrm{SERV})_{\mathrm{ij}}{ }^{*}$ Technology gap $\mathrm{ij} \mathrm{t}-1$ & $\begin{array}{r}0.02 \\
(0.02)\end{array}$ & $\begin{array}{r}0.02 \\
(0.02)\end{array}$ & \\
\hline Barriers to entry (SERV) (non-comp) ${ }_{\mathrm{ij}}{ }^{*}$ Technology gap ${ }_{\mathrm{ij} \text { t-1 }}$ & & & $\begin{array}{r}\mathbf{0 . 0 4 9} \\
(0.06)\end{array}$ \\
\hline Barriers to entry (SERV) (comp) ${ }_{i j}$ * Technology gap ${ }_{i j t-1}$ & & & $\begin{array}{r}0.024 \\
(0.02)\end{array}$ \\
\hline Entry liberalisation $(\mathrm{SERV})_{\text {it }}$ & $\begin{array}{c}0.04^{* *} \\
(0.01)\end{array}$ & $\begin{array}{l}0.04^{* * *} \\
(0.01)\end{array}$ & $\begin{array}{l}0.04^{* * *} \\
(0.01)\end{array}$ \\
\hline Entry liberalisation (MAN) it & $\begin{array}{r}0.04 \\
(0.10)\end{array}$ & & \\
\hline Overall privatisation $_{i t}$ & $\begin{array}{c}0.23 \text { ** } \\
(0.10) \\
\end{array}$ & $\begin{array}{c}0.24^{* *} \\
(0.10) \\
\end{array}$ & $\begin{array}{r}0.24^{* *} \\
(0.10)\end{array}$ \\
\hline $\begin{array}{l}\text { Number of observations } \\
\text { Reset }^{1}\end{array}$ & $\begin{array}{r}3093 \\
1.92 \\
\end{array}$ & $\begin{array}{r}3093 \\
1.51 \\
\end{array}$ & $\begin{array}{r}3093 \\
1.67 \\
\end{array}$ \\
\hline
\end{tabular}

*** denotes significance at the $1 \%$ level; ${ }^{\star *}$ at $5 \%$ level; * at $10 \%$ level.

Robust standard errors.

Samples are adjusted for outliers. See main text.

All equations include country, industry and time dummies.

Indicators of privatisation measure the change in public ownership; entry liberalisation measures the easing

of restrictions imposed on market mechanisms; and entry barriers the strincency of such regulations.

1. Ramsey's omitted-variable test: F-test on the joint significance of the additional terms

in a model augmented with the second, third and fourth powers of the predicted values

of the original model. 
56. To this end, in the final step of our analysis we used industry-level indicators, exploiting the wide cross-industry dispersion of regulations. We focus on barriers to entry, entry liberalisation and privatisation. The results in Table 8 seem to confirm those presented in the previous two tables, but also add interesting insights. In particular, while entry liberalisation in services seems to have a positive effect on productivity in the whole economy (equations 1 and 3), the effect of such liberalisation in manufacturing (proxied by easing of trade restrictions) is not significant. At the same time, there is clear evidence of a positive effect of privatisation on MFP. The results also suggest that restrictive industry-specific regulations affect productivity mainly via the process of adoption and technological catch-up in manufacturing, while, a slightly positive direct effect of restrictive regulation on MFP is found in service industries.

57. This surprising result for the service sector may be due to the significant heterogeneity of market and regulatory conditions characterising the individual service industries. For example, in industries where the regulator has extensive control on business choices ((e.g. railways), it is possible that efficiencyenhancing investments can be forced upon the regulated firm - though at the expense of higher regulated prices. To shed light on the potential role of industry heterogeneity, in the last column of the table, we split service industries into a group of activities characterised by competitive market conditions (trade, hotels and restaurants, financial intermediation and real estate and business activities) and a residual group characterised by a mixture of competitive and natural monopoly elements (transport and post and telecommunications). However, when we distinguish between the two sets of service industries, the positive direct effect becomes insignificant. At the same time, there is evidence that in competitive service industries the indirect effect of regulation is marginally stronger in statistical terms. This is consistent with the idea that regulations affect more strongly technology adoption in competitive markets than in natural monopoly markets, where competitive pressures are uniformly weaker and neck-and-neck competition is less widespread. This tentative conclusion, however, requires further investigation at a finer level of industry disaggregation.

\section{Concluding remarks}

58. This paper addressed two related policy-relevant issues. First, we asked whether the product market reforms implemented by OECD governments over the past two decades have led to convergence in international business environments. Using a novel set of data on product market regulations and regulatory reforms, we show that the answer to this question is nuanced. On the one hand, product markets of virtually all OECD countries have become more market friendly. On the other hand, policy approaches have never been so different as in recent times, especially (and surprisingly) within the EU. This is because the pace of reform has varied significantly across countries that already had very different policy approaches at the beginning of the period. At the same time, market integration, EC competition policies and the EMU apparently did not provide sufficient constraints and/or incentives to European governments for harmonising their product markets, which remained largely under the realm of domestic policies often unfriendly to competition. ${ }^{54}$ This led to the second question addressed in our paper: can these diverging patterns of reform contribute to explain the puzzling disparities in growth outcomes over the past decade, when a number of countries halted and, sometimes, reversed the long-standing productivity slowdown while others continued along a downward-sloping productivity path? Our empirical analysis tends to provide a positive answer to this question. Both the bivariate and multivariate evidence we present point to significant links between product market policies and productivity performance. We identified two main channels. role or stringent guidelines on product-market reforms by member governments. 
59. First, the lower entry barriers and state control the faster the process of catch-up to best-practice technologies in manufacturing industries. This has the ancillary implication that countries that are laggards in both technology adoption and reform are likely to reap the largest productivity gains from state retrenchment and liberalisation of markets that are potentially competitive. To the extent to which Europe has accumulated a technology gap in some high-tech industries (e.g. ICT-related industries), this result points to the importance of further regulatory reforms aimed at easing entry conditions and reducing state control. At the same time, we also find evidence that entry liberalisation involves productivity gains in all countries, regardless of their position with respect to the technology frontier.

60. Second, we found evidence to suggest that the process of privatisation involves additional direct productivity gains. This is consistent with theories pointing to the increased competitive pressures and entrepreneurial incentives stemming from changes in ownership. However, as often argued, the gains from privatisation may depend on whether the state maintains large stakes in such privatised companies (as in the case of large energy, telecommunication and transport companies in Europe) or not. Even more importantly, efficiency gains may depend on whether privatisation is accompanied by adequate promotion of competition in the markets in which privatised companies operate. These are, however, issues that could not be tackled in our analysis and require further empirical work.

61. Bearing in mind the illustrative nature of any policy simulation based on aggregate regressions, our empirical results seem to suggest sizeable benefits from further progress in reforming the regulatory environment and in reducing the role of the state in business activities. In particular, if taken at face value, a gradual (over ten years) move to the OECD-wide average share of state-owned firms in total value added is estimated to boost annual MFP productivity growth by about 0.7 percentage points in some European countries, most notably Finland, Greece, Austria, France and Italy that still have a large stake of business activities in public hands. This acceleration in productivity growth could last as long as the privatisation process continues and the economy has not yet reached the new steady-state productivity growth path. Clearly, the productivity gains that can potentially be obtained through state retrenchment are large, but they are also bounded by the size of the public enterprise sector. Perhaps more importantly, we found that entry liberalisation aimed at moving the level of barriers to entry in some European countries towards the OECD average over a ten-year time horizon might have a two-fold effect. First, entry liberalisation in service industries is estimated to boost annual MFP growth in the overall business sector by about $0.1-0.2$ percentage points in countries like Portugal, Greece and Italy. Second, there is also an indirect effect of the removal of trade and administrative barriers to entry in excess of those existing in the average OECD country. This effect depends on the technology gap that countries have accumulated in some heavily regulated manufacturing industries: such reforms are estimated to boost manufacturing-wide annual productivity growth by $0.1-0.2$ in some European countries and most notably Germany, France, Italy and Greece.

62. All in all, these findings seem to offer some insights into the current debate about policy reform in the EU area. Evidence of large differences in regulatory patterns within Europe and, even more importantly, divergence in the pace of regulatory reforms raises the issue as to whether appropriate instruments are set in place to favour the harmonisation of the European business environment and make Europe "the most competitive and dynamic knowledge-based economy in the world" as stated at the Lisbon Summit in 2000. Indeed, while the single market agenda is well underway and subject to a close monitoring process (e.g. the Single Market Scoreboard), the review of product market regulations and regulatory reform in EU countries, now part of the Cardiff process, probably requires further efforts. Likewise, despite efforts to improve transparency and enforce discipline, the degree of state intervention has remained highly differentiated across the EU states, with potentially negative competitive effects across EU countries. 
63. We cannot conclude this paper without a word of caution on the limits of the available information about regulations and state intervention. For example, data limitations did not make it possible to estimate accurately the relative contributions of industry-specific privatisation and entry liberalisation to productivity improvements. This calls for further work on characterising public ownership at the industry level. Moreover, our characterisation of entry regulation in manufacturing could not account for important crosscountry and cross-industry differences related to standards, quality control, environmental regulations and industry-specific administrative burdens, which may have an important influence on productivity. Here too, a further effort to quantify differences in regulation across countries would be needed. Finally, while great care was taken to assess and quantify differences in service regulation across countries and time, no long-run effects of entry barriers on MFP in these industries could be detected from the empirical analysis. This result runs against the abundant evidence pointing to efficiency improvements after the liberalisation of service industries such as telecommunications. We believe that our failure to detect such effects in the data may partly depend on the poor quality of the productivity data for services, which are marred by inaccurate measurement of both (or either) inputs and outputs. Many of the studies dealing with the effects of increased competition in specific industries used $a d$ hoc productivity measures (e.g. in physical units or based on frontier analysis), while we based our multi-factor productivity measures on standard national accounts data and defined it uniformly across manufacturing and service industries. This points to a trade-off, often faced by analysts, between the wish to broaden the analysis to a cross-industry/cross-country panel, which can only be done by relying on standardised data, and the wish to quantify phenomena that are grounded in microeconomic relationships and whose evidence may be clouded by excessive generalisation. 


\section{References}

AGHION, P. and P. HOWITT (1992), “A Model of Growth through Creative Destruction”, Econometrica, Vol. 60, pp. 323-51.

AGHION, P., and P. HOWITT , (1998), Endogenous Growth Theory, Cambridge: Mass.: The MIT Press.

AGHION, P., C. HARRIS, P. HOWITT and J. VICKERS (2001), "Competition, Imitation and Growth with Step-by-Step Innovation", Review of Economic Studies, forthcoming.

BAILY, M.N., and H. GERSBACH (1995), "Efficiency in Manufacturing and the Need for Global Competition”, Brooking Papers on Economic Activity: Microeconomics pp. 307-308.

BASSANINI A. and E. ERNST (2002), "Labour Market Institutions, Product Market Regulations and Innovation: Cross-Country Evidence”, OECD Economics Department Working Papers, No. 316.

BASSANINI, A. and S. SCARPETTA (2002), "Growth, Technological Changes and ICT Diffusion: Recent Evidence from OECD Countries", Oxford Review of Economic Policy 18(3).

BELSLEY, D.A., E. KUH, and R.E. WELSCH (1980), Regression Diagnostics: Identifying Influential Data and Sources of Collinearity, New York, John Wiley \& Sons.

BERNARD, A., and C.I. JONES (1996a), "Comparing Apples to Oranges: Productivity Convergence and Measurement across Industries and Countries", The American Economic Review, vol.86 No.5, pp. 1216-38.

BERNARD, A., and C.I. JONES (1996b), "Productivity Across Industries and Countries: Time-Series Theory and Evidence", The Review of Economics and Statistics, pp. 135-146.

BERNARD, A., and C.I. JONES (1996c), "Productivity and Convergence across U.S. States and Industries", Empirical Economics, 21, 113-135.

BLANCHFLOWER, D. and S. MACHIN (1996), "Product market competition, wages and productivity: international evidence from establishment-level data", Centre for Economic Performance, Discussion paper No. 286, April.

BLUNDELL, R., R. GRIFFITH and J. VAN REENEN (1995), "Dynamic Count Data Models of Technological Innovation”, Economic Journal, Vol. 105, pp. 333-344.

BLUNDELL, R., R. GRIFFITH and J. VAN REENEN (1999), "Market Share, Market Value and Innovation in a Panel of British Manufacturing Firms", Review of Economic Studies, Vol. 66, pp. 529-554.

BOONE, J. (2000a), "Competition”, Center Discussion Paper No.2000-104, Tilburg University, Netherlands, October. 
BOONE, J. (2000b), "Competitive Pressure: The Effects on Investments in Product and Process Innovation", RAND Journal of Economics, Vol. 31, No. 3, pp. 549-569.

BOYCKO, M., A. SHLEIFER and R.W. VISHNY (1996), "A theory of privatisation”, The Economic Journal, March.

CAVES, D. L. CHRISTENSEN and E. DIEWERT (1982), "Multilateral comparisons of output, input, and productivity using superlative index numbers", Economic Journal, 92.

CAVES, R.E., and BARTON (1990), Efficiency in US Manufacturing Industries. MIT Press.

CEEP (2000), "The development of enterprises of public participation and of general economic interest in Europe since 1996”, CEEP Statistical Review, Bruxelles.

CHATTERJEE and HADI (1988), "Sensitivity Analysis in Linear Regression", New York, Wiley.

CHEUNG, Y.W., and A. GARCIA PASCUAL (2001), "Market Structure, Technology Spillovers, and Persistence in Productivity Differentials", CESifo Working Paper series, No. 517.

CLAESSENS, S., S. DJANKOV and G. POHL (1997), "Ownership and corporate governance: Evidence from the Czech Republic”, World Bank, Washington DC, Policy Research Paper, No. 1737.

CRAGG, M.I. and I.J.A. DYCK (1999), "Management control and privatization in the United Kingdom", RAND Journal of Economics, Vol. 30, No. 3, pp. 475-497.

D'SOUZA, J. and W.L. MEGGINSON (1999), "The financial and operating performance of privatized firms during the 1990s", Journal of Finance, 54(4), pp. 1397-1438.

DE LA FUENTE and R. DOMËNECH (2000), "Human Capital in Growth Regressions: How Much Does Data Make?", OECD Economics Department Working Paper No. 262, Paris.

DISNEY, R., J. HASKEL and Y. HEDEN (2000), "Restructuring and productivity growth in UK manufacturing", CEPR Discussion paper series, No. 2463, May.

DUSO, T., and L-H. RÖLLER (2001), “Towards a Political Economy of Industrial Organization: Empirical Regularities from Deregulation”, Discussion Paper FS IV 01-17, Wissenschaftszentrum Berlin.

ECKEL, C., D. ECKEL and V. SINGHAL (1997), "Privatization and efficiency: Industry effects of the sale of British Airways", Journal of Financial Economics, 43, pp. 275-298.

ESTRIN, S. and V. PÉROTIN (1991), “Does ownership always matter?”, International Journal of Industrial Organization, 9, 55-72.

FRYDMAN, R., C. GRAY, M. HESSEL, A. RAPACZYNSKI (1999), "When does privatization work? The impact of private ownership on corporate performance in the transition economies", The Quarterly Journal of Economics, November.

GARCIA PASCUAL, A and F. WESTERMANN (2001), "Productivity Convergence in European Manufacturing", Review of International Economics. 
GÖNENÇ, R., M. MAHER and G. NICOLETTI (2001), "The implementation and the effects of regulatory reform: past experience and current issues", OECD Economic Studies, No. 32, OECD, Paris.

GREEN, A. and D.G. MAYES (1991). “Technical Efficiency in Manufacturing Industries” Economic Journal, 101, 523-538.

GREENWOOD, J., Z. HERCOWITZ and P. KRUSELL (1997), "Long-Run Implications of InvestmentSpecific Technological Change”, American Economic Review, Vol. 87, pp. 342-362.

GRIFFITH R., S. REDDING and J. van REENEN (2000), "Mapping the two faces of R\&D: Productivity growth in a panel of OECD industries", IFS working paper W00/02.

GWARTNEY, J. and R. LAWSON (2001), "Economic freedom of the world - 2001 Annual Report", The Fraser Institute, Vancouver.

HARRIGAN, J. (1999), "Estimation of Cross-country Differences in Industry Production Functions", Journal of International Economics, 47(2), April, pp. 267-93

HASKEL, J. and A. SANCHIS (1995), "Privatisation and X-inefficiency: A Bargaining Approach", The Journal of Industrial Economics, Vol. 43, No. 3, September.

HERCOWITZ, Z. (1998), “The "Embodiment" Controversy: A Review Essay”, Journal of Monetary Economics, Vol. 41, pp. 217-224.

JEAN, S. and G. NICOLETTI, (2001), "Product market regulation and wage premia in Europe and North america: an empirical investigation", OECD Economics Department Working Papers, n. 318, Paris.

KAUFMANN, D., A. KRAAY, and P. ZOLDO-LOBATÓN, (1999), "Aggregating Governance Indicators," www.worldbank.org/wbi/governance/

KAY, J.A. and D.J. THOMPSON (1986), "Privatisation: A Policy in Search for a Rationale", Economic Journal 96(381), March, pp. 18-32.

KLINE, P. (1994), An Easy Guide to Factor Analysis, Routledge, London and New York.

FINDLAY, C. and T. WARREN (eds) (2000), Impediments to Trade in Services: Measurement and Policy Implications, Routledge, London and New York,

LAFFONT, J.J. and J. TIROLE (1993), A Theory of Incentives in Procurement and Regulation, Cambridge, MA: MIT Press.

LAZAER,E.P and S. ROSEN (1981), "Rank-order tournaments as optimum labor contracts". Journal of Political Economy, 89, 841-864.

MACDONALD, J.M., (1994), “Does Import Competition Force Efficient Production?", Review of Economics and Statistics, 76(4), pp.721-727.

McKINSEY Global Institute (1997), Removing Barriers to Growth and Employment in France and Germany, McKinsey. 
MEGGINSON, W.L. and J.M. NETTER (2001), "From state to market: A survey of empirical studies on privatization", The Journal of Economic Literature, Vol. 39, No. 2, June.

MEYER, M., and J. VICKERS, (1997), "Performance Comparisons and Dynamic Incentives," Journal of Political Economy, 105, 3, 547-581.

MORRISON, C.J. (1992), "Unraveling the Productivity Growth Slowdown in the United States, Canada, and Japan: The Effects of Subequilibrium, Scale Economies and Markups", Review of Economics and Statistics, Vol. 74, pp. 381-393.

MOULTON, B.R. (1986), "Random group effects and the precision of regression estimates", Journal of Econometrics, 32, pp. 385-397.

NALEBUFF, B., and J. STIGLITZ (1983), "Information, Competition and Markets", American Economic Revue, Papers and Proceedings 73, 278-93.

NICKELL, S., D. NICOLITSAS and N. DRYDEN (1997), "What makes firms perform well?", European Economic Review, 41.

NICKELL, S. (1996), "Competition and Corporate Performance", Journal of Political Economy, Vol. 104, pp. 724-746.

NG, C.K. and P. SEABRIGHT (2001), "Competition, Privatisation and Productive Efficiency: Evidence from the Airline Industry", Economic Journal, 111 (July), pp. 591-619.

NICOLETTI, G. (2002), “Institutions, Economic Structure and Performance: Is Italy Doomed?", ISAE Annual Report on Monitoring Italy, January, Rome.

NICOLETTI, G. A. BASSANINI, E. ERNST, S. JEAN, P. SANTIAGO and P. SWAIM (2001), "Product and Labour Market Interactions in OECD Countries", OECD Economics Department Working Paper No. 312, Paris.

NICOLETTI, G. and R. PRYOR, (2001), "Subjective and Objective Measures of the Extent of Governmental Regulations", http://www.aei.brookings.org/publications/related/measures.pdf

NICOLETTI, G. and S. SCARPETTA (2002), "Interactions between product and labour market regulations: do they affect employment? Evidence from OECD countries", OECD Economics Department Working Papers, forthcoming.

NICOLETTI, G., S. SCARPETTA and O. BOYLAUD (1999), "Summary indicators of product market regulation with an extension to employment protection legislation", OECD Economics Department Working Paper No. 226, Paris.

OECD (1997a), The OECD Report on Regulatory Reform, Volume II Thematic Studies, Paris.

OECD (1997b), The OECD Report on Regulatory Reform, Paris.

OECD (1999), OECD Economic Survey of Mexico, Paris.

OECD (2001a), The New Economy Beyond the Hype: The OECD Growth Project, Paris. 
OECD (2001b), OECD Economic Studies No. 32, Special issue on regulatory reform, Paris.

OECD (2001c), Financial Market Trends, n. 81, OECD, Paris.

OECD (2001d), Regulatory Reform in Greece, OECD Reviews of Regulatory Reform, OECD, Paris.

OECD (2001e), Regulatory Reform in Italy, OECD Reviews of Regulatory Reform, OECD, Paris.

OXFORD REVIEW OF ECONOMIC POLICY, (2001), European Network Infrastructures, Vol. 17, No. 3 , Autumn, Oxford University Press.

PORTER, M. (1990) The Competitive Advantage of Nations, London: MacMillan Press.

PRYOR, F. L. (2002), "Quantitative Notes on the Extent of Governmental Regulations in Various OECD Nations," International Journal of Industrial Organization, (20)5, pp. 693-714.

SCARPETTA, S., A. BASSANINI, D. PILAT and P. SCHREYER (2000), "Economic growth in the OECD area: recent trends at the aggregate and sectoral level", OECD Economics Department Working Papers, No. 248.

SCARPETTA, S. AND T. TRESSEL (2002a), "Productivity and Convergence in a Panel of OECD industries: Do Regulations and Institutions Matter?", OECD Economics Department Working Papers, forthcoming.

SCARPETTA, S. AND T. TRESSEL (2002b), "Technological change, productivity growth and labour market institutions: An empirical investigation for OECD countries”, mimeo.

SCARPETTA, S., P. HEMMINGS, T. TRESSEL and J. WOO (2002), "The Role of Policy and Institutions for Productivity and Firm Dynamics: Evidence from Micro and Industry Data", OECD Economics Department Working Papers No. 329, Paris.

SHLEIFER, A., and R. B. VISHNY (1994), "Politicians and Firms", The Quarterly Journal of Economics, November, pp. 995-1025.

SHLEIFER, A. and R.W. VISHNY (1997), "A survey of corporate governance", The Journal of Finance, Vol. LII, No. 2, June.

SHLEIFER, A. (1998), "State versus private ownership", The Journal of Economic Perspectives, Vol. 12 No. 4, pp. 133-150.

SCHMIDT, K. M. (1996)," "The Costs and Benefits of Privatization: An Incomplete Contracts Approach", Journal of Law, Economics and Organization, 12(1), pp. 1-24.

SØRENSEN, A. (2001), "Comparing Apples and Oranges: Productivity Convergence and Measurement Across Industries and Countries: Comment", American Economic Review, 91, 4, pp. 1160-1167.

STEINER, F. (2001), "The Market Response to Restructuring: A Behavioral Model”, mimeo, Stanford University. 
VAN WINJNBERGEN, S., and A. J. VENABLES (1993). “Trade Liberalization, Productivity, and Competition: The Mexican Experience," mimeo, Centre for Economic Performance, London School of Economics.

WINSTON, C. (1993), "Economic deregulation: Days of reckoning for microeconomists", Journal of Economic Literature, Vol. XXX1, pp. 1263-1289, September. 


\section{Appendices}

\section{Regulation data and indicators}

64. Four sets of regulatory indicators are used in the paper. These describe economy-wide regulation; industry-level regulation; regulatory reform and privatisation. Economy-wide regulation covers different regulatory areas (e.g. state control, barriers to entrepreneurship, administrative regulation) and summarises, for each area and overall, general-purpose and industry-specific regulations into a single indicator that describes the situation in each country in 1998. Industry-level regulations concern barriers to international trade in manufacturing and a wide set of regulatory areas (including public ownership, barriers to entry, constraints to business operation and price controls) in non-manufacturing industries. The manufacturing indicators cover the 1988, 1993 and 1996 periods. The non-manufacturing indicators cover 16 industries in 1998 and 7 industries over the 1975-1998 period. Regulatory reform is defined as trade liberalisation and administrative simplification in the manufacturing sector, and market-oriented regulatory changes in the 7 non-manufacturing industries for which historical data on regulation is available. Privatisation has a more restricted focus and aims at summarising into a single time-series indicator the evolution of public ownership in the aggregate business sector over the 1975-1998 period. Figure A.1 provides an overall taxonomy of the economywide and industry-level regulatory indicators. More details on each of these indicators are provided below.

\subsection{Economy-wide regulation}

65. The indicators of economy-wide regulation are drawn from Nicoletti et al. (1999), who describe in detail data sources, assumptions and methodologies. These indicators are based on detailed data collected by the OECD from national sources concerning regulations potentially restricting private governance and competition (the OECD International Regulation Database is available on line at http://www.oecd.org/EN/document/0,,EN-document-491-nodirectorate-no-1-18275-2,00.html).

Nicoletti et al. (1999) grouped the data in two main regulatory areas: inward-oriented regulations and barriers to trade and investment. Inward-oriented regulations were further subdivided into two alternative sets of areas: state control and barriers to entrepreneurship; or economic and administrative regulation.

66. In this paper, the economy-wide indicator of administrative regulation was used to supplement industry-level information about trade barriers in manufacturing and as a proxy for industry-level regulation in the Hotels and Restaurants industry, for which no other regulatory information was available. By way of illustration, Table A.1 describes the basic composition of this indicator and the various aggregation steps. 
Figure A.1. A map of indicators of regulation

(indicators used in empirical analysis are highlighted in grey)

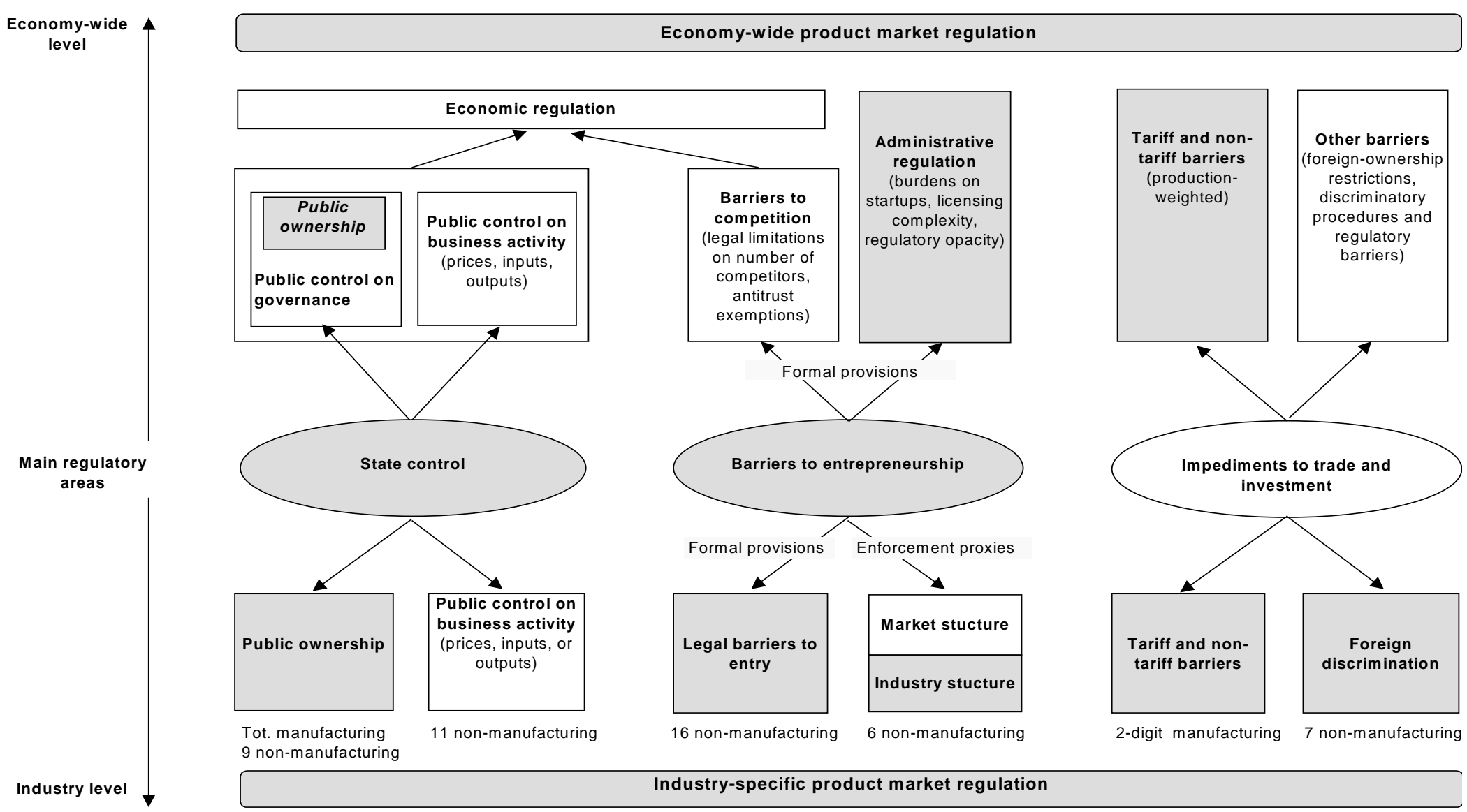


Table A.1. Indicator of administrative regulation: basic components and aggregation steps

Panel A. Administrative regulation

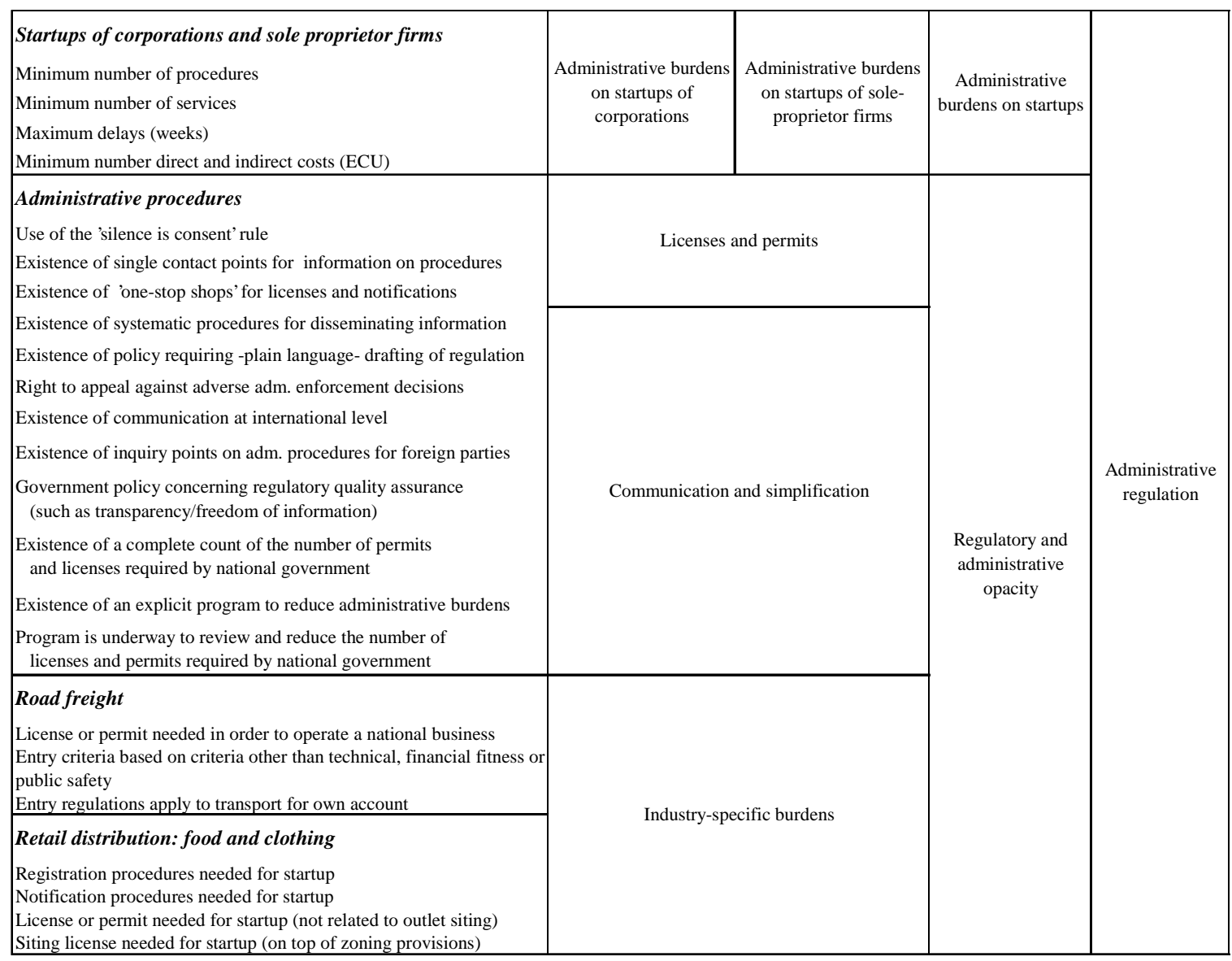

67. Summary indicators, for each regulatory area and overall, were computed aggregating individual regulations with weights derived from factor analysis. This technique was used as a descriptive device to identify clusters of regulatory provisions belonging to the same (unobserved) regulatory sub-areas, yielding the taxonomy of economy-wide indicators sketched in the upper part of Figure A.1. ${ }^{55}$ For instance, regulations falling under the administrative regulation umbrella were subdivided into administrative burdens on start-ups and regulatory and administrative opacity (Table A.1), those under the state control umbrella were subdivided among the two sub-areas of public ownership and government involvement in business operation, etc. Regulations belonging to the same sub-area (i.e. attached to the same unobserved principal component) were then aggregated using their loading in each principal component. Thus, the weight of individual regulations in each sub-area indicator reflects its contribution to the cross-country variance of the data, with more weight given to regulations that are more variable across countries. The final aggregation into a global indicator of product market regulation was made by simple averaging of the area-wide indicators resulting from

55 Factor analysis is a statistical technique aimed at finding the minimum number of factors that explain the maximum amount of the overall covariance of the observed variables. Each observed variable is assigned to the factor that it mostly contributes to determine. Kline (1994) provides a good illustration of factor analysis techniques. Kaufmann et al. (1999) used factor analysis as a statistical device to aggregate and make probabilistic statements about "subjective" measures of regulation. 
factor analysis. As shown in the main text, the resulting country rankings, along both the global and area-wide indicators of regulation, are robust to changes in the weighting procedure.

68. The country rankings obtained for the economy-wide indicators are also broadly consistent with the rankings obtained by other authors using different data and methodologies (Table A.2). Though differences in the ranking of individual countries exist, the overall correlation among the indices shown in the table is strong and significant at conventional levels. Moreover, if we define in each ranking the first six countries as liberal and the last six as regulated, the overlap is remarkable. As suggested in the main text, most differences can be traced to the "subjective" nature of the data used in the alternative indicators, which are mostly based on results of business surveys.

Table A.2. Subjective and objective measures of economy-wide product market regulation, late 1990s

Panel A. Scores and Ranks

\begin{tabular}{lcc|cc|cc} 
& \multicolumn{2}{c}{ Nicoletti et al. $(1999)$} & Kaufman et al. (1999) & \multicolumn{2}{c}{ Pryor (2002) } \\
& Scores & Ranks & Scores & Ranks & Scores & Ranks \\
\cline { 2 - 7 } Australia & 0.24 & 3 & 0.30 & 8 & 0.40 & 12 \\
Austria & 0.49 & 8 & 0.37 & 10 & 0.39 & 11 \\
Belgium & 0.80 & 17 & 0.50 & 17 & 0.74 & 18 \\
Canada & 0.54 & 11 & 0.41 & 14 & 0.24 & 6 \\
Denmark & 0.50 & 9 & 0.19 & 7 & 0.38 & 10 \\
Finland & 0.67 & 14 & 0.08 & 5 & 0.00 & 1 \\
France & 0.88 & 18 & 0.60 & 18 & 0.78 & 19 \\
Germany & 0.52 & 10 & 0.39 & 11 & 0.31 & 7 \\
Greece & 0.97 & 20 & 0.74 & 19 & 1.00 & 21 \\
Ireland & 0.20 & 2 & 0.06 & 3 & 0.32 & 8 \\
Italy & 1.00 & 21 & 0.75 & 20 & 0.87 & 20 \\
Japan & 0.58 & 12 & 1.00 & 21 & 0.61 & 15 \\
Netherlands & 0.49 & 7 & 0.08 & 4 & 0.15 & 4 \\
New Zealand & 0.43 & 5 & 0.00 & 2 & 0.13 & 3 \\
Norway & 0.97 & 19 & 0.34 & 9 & 0.60 & 14 \\
Portugal & 0.70 & 15 & 0.39 & 12 & 0.65 & 17 \\
Spain & 0.64 & 13 & 0.42 & 15 & 0.58 & 13 \\
Sweden & 0.49 & 6 & 0.43 & 16 & 0.37 & 9 \\
Switzerland & 0.76 & 16 & 0.40 & 13 & 0.01 & 2 \\
United Kingdom & 0.00 & 1 & 0.00 & 1 & 0.16 & 5 \\
United States & 0.28 & 4 & 0.09 & 6.62 & 16
\end{tabular}

Panel B. Correlation coefficients $(\mathbf{R})$

\begin{tabular}{|c|c|c|c|}
\hline $\begin{array}{l}\text { Nicoletti et al. (1999) } \\
\text { Kaufman et al. (1999) } \\
\text { Pryor (2002) }\end{array}$ & 1.00 & $\begin{array}{c}0.64 * \\
1.00\end{array}$ & $\begin{array}{c}0.55^{*} \\
0.67 * \\
1.00\end{array}$ \\
\hline
\end{tabular}

Notes:

A high number indicates a greater degree of regulation and all indices are scaled from 0 to 1 .

The original indices were, therefore, reversed (when necessary) and rescaled. The data come from

Nicoletti, Scarpetta, and Boylaud (1999), Pryor (2002) and Kaufman et al. (1999).

For correlations an asterisk designates statistical significance at the 0.05 level.

Source: Nicoletti and Pryor (2002). 


\subsection{Industry-level regulation}

69. The indicators of industry-level regulation used in the paper cover the manufacturing and (most of the) utilities and marketable service industries at the 2 or higher digits of aggregation (according to the ISIC Rev 3 classification). In network industries -- such as utilities, post and telecommunications and railways -- the basic data covered regulatory and market conditions in different (vertical or horizontal) segments of the industries (e.g. gas production, distribution and supply; or regular and express mail). Table A.3 provides the coverage and sources of the regulatory data for the industry aggregates used in Sections 3 and 4 of the paper.

Table A.3. Industry-level indicators: sources and sample coverage

\begin{tabular}{|c|c|c|c|c|c|}
\hline Industry & $\begin{array}{l}\text { ISIC code } \\
\text { Revision } 3\end{array}$ & Period & $\begin{array}{l}\text { Industrial segments } \\
\text { covered }\end{array}$ & $\begin{array}{l}\text { Countries } \\
\text { covered }\end{array}$ & Main sources \\
\hline Manufacturing & $15-37$ & $1988,1993,1996$ & & 25 & UNCTAD, OECD \\
\hline Electricity, gas and water & 40_41 & 1998 & & 23 & OECD, EC, PI, WB \\
\hline Electricity & 401 & $\begin{array}{c}1998 \\
1975-1998 \\
\end{array}$ & Prod., Trans., Dist. & $\begin{array}{c}24-25 \\
21\end{array}$ & $\begin{array}{c}\text { OECD } \\
\text { OECD, EC, PI, WB }\end{array}$ \\
\hline Gas manufacture and distribution & 402 & $\begin{array}{c}1998 \\
1975-1998 \\
\end{array}$ & Prod., Trans., Dist. & $\begin{array}{l}26 \\
21\end{array}$ & OECD, EC, PI, WB \\
\hline Water works and supply & 41 & 1998 & & 23 & OECD, EC, PI, WB \\
\hline $\begin{array}{l}\text { Wholesale and Retail Trade, Hotels and } \\
\text { Restaurants }\end{array}$ & $50 \_52$ & 1998 & & 25 & OECD \\
\hline Retail trade & 52 & 1998 & & 28 & OECD \\
\hline Transport and Storage & 60_63 & 1998 & & 21 & $\begin{array}{c}\text { OECD, ECMT } \\
\text { EC, APC }\end{array}$ \\
\hline Railways & 601 & $\begin{array}{c}1998 \\
1975-1998 \\
\end{array}$ & Passenger, freight & $\begin{array}{l}27 \\
21 \\
\end{array}$ & OECD, ECMT \\
\hline Road freight & 602 & $\begin{array}{c}1998 \\
1975-1998 \\
\end{array}$ & & $\begin{array}{c}27-29 \\
21 \\
\end{array}$ & $\begin{array}{c}\text { OECD } \\
\text { OECD, ECMT }\end{array}$ \\
\hline Water transport & 61 & 1998 & & 22 & APC \\
\hline Air transport carriers & 62 & $\begin{array}{c}1998 \\
1975-1998\end{array}$ & Passenger & $\begin{array}{l}27 \\
21\end{array}$ & $\begin{array}{c}\text { OECD } \\
\text { OECD, EC }\end{array}$ \\
\hline Supporting services to transport & 63 & 1998 & & 21 & OECD \\
\hline Post and telecommunications & 64 & 1998 & $\begin{array}{l}\text { Mobile and fixed } \\
\text { telephony }\end{array}$ & 26 & OECD \\
\hline Post & 641 & $\begin{array}{c}1998 \\
1975-1998 \\
\end{array}$ & Letter, parcel, express & $\begin{array}{c}22-26 \\
21\end{array}$ & OECD, EC, UPU \\
\hline Telecommunications & 642 & $\begin{array}{c}1998 \\
1975-1998 \\
\end{array}$ & Fixed, mobile & $\begin{array}{c}20-29 \\
21\end{array}$ & OECD \\
\hline Financial intermediation & $65 \_67$ & 1998 & & 23 & OECD, APC \\
\hline Financial institutions & 65 & 1998 & & 23 & OECD, APC \\
\hline Professional business services & 74 & 1998 & & 22 & APC \\
\hline Legal services & 7411 & 1998 & & 22 & APC \\
\hline Accounting services & 7412 & 1998 & & 23 & APC \\
\hline Architectural and engineering services & 7421 & 1998 & & 23 & APC \\
\hline
\end{tabular}

Legend:

ECMT = European Conference of Ministers of Transportation

$\mathrm{EC}$ = European Commission

WB = World Bank

$\mathrm{PI} \quad=$ Privatisation International

APC = Australian Productivity Commission

UPU $=$ Universal Postal Union 
70. Depending on the industry, the regulatory areas covered by the industry-level indicators include barriers to entry, trade or FDI restrictions, public ownership, price controls, constraints to business operation, vertical integration and market concentration (Table A.4). Differences in coverage depend on both the availability of data and the relevance of the regulatory areas for each individual industry (e.g. in OECD countries, public ownership is not a relevant factor in the road freight industry, and vertical integration is generally not relevant for professional services). In network industries, measures of industry and market structure were included as proxies for de facto entry barriers for new service providers. However, to avoid potential endogeneity problems market concentration was netted out of the indicators used in the econometric analysis of MFP determinants (Section 4).

Table A.4. Industry-level indicators: coverage of regulatory $\operatorname{areas}^{1}$

\begin{tabular}{|c|c|c|c|c|c|c|c|c|}
\hline & $\begin{array}{l}\text { Barriers } \\
\text { to entry }\end{array}$ & $\begin{array}{c}\text { Public } \\
\text { ownership }\end{array}$ & $\begin{array}{c}\text { Market } \\
\text { structure }\end{array}$ & $\begin{array}{c}\text { Vertical } \\
\text { integration }\end{array}$ & $\begin{array}{c}\text { Price } \\
\text { controls }\end{array}$ & $\begin{array}{c}\text { Constraints } \\
\text { on business } \\
\text { operation }\end{array}$ & $\begin{array}{c}\text { Administrative } \\
\text { burdens }\end{array}$ & $\begin{array}{c}\text { Trade or FDI } \\
\text { restrictions }\end{array}$ \\
\hline Airlines & $x$ & $x$ & $x$ & & $x$ & & & $x$ \\
\hline Railways & $\mathrm{x}$ & $\mathrm{X}$ & $\mathrm{x}$ & $\mathrm{X}$ & $\mathrm{X}$ & & & \\
\hline Road & $\mathrm{x}$ & & & & $x$ & $x$ & $x$ & $x$ \\
\hline Water transport & $\mathrm{X}$ & & & & & $x$ & & $\mathrm{x}$ \\
\hline Gas & $\mathrm{x}$ & $\mathrm{x}$ & $x$ & $\mathrm{x}$ & $x$ & & & \\
\hline Water & $x$ & $x$ & & $x$ & & & & \\
\hline Electricity & $\mathrm{x}$ & $\mathrm{X}$ & $\mathrm{x}$ & $\mathrm{X}$ & & & & \\
\hline Post & $x$ & $x$ & & $x$ & $x$ & & & \\
\hline Telecommunications & $x$ & $x$ & $x$ & $x$ & $x$ & & & \\
\hline Retail distribution & $x$ & & & & $x$ & $x$ & $x$ & \\
\hline Financial services & $x$ & & & & $x$ & $x$ & & $x$ \\
\hline Legal services & $x$ & & & & & $x$ & & $x$ \\
\hline Accounting services & $x$ & & & & & $x$ & & $x$ \\
\hline $\begin{array}{l}\text { Architectural and } \\
\text { engineering services }\end{array}$ & $x$ & & & & & $\mathrm{x}$ & & $\mathrm{x}$ \\
\hline Manufacturing & & & & & & & & $x$ \\
\hline
\end{tabular}

1. All items refer to 1998. Items shaded in grey have a time-series dimension.

71. The precise definition of each of the regulatory areas also varies across industries as a function of both industry characteristics and data availability. The main items included in the industry-specific definitions are summarised in Table A.5. Countries were ranked along each item according to a scale going from least to most restrictive of private governance or competition. Further details on the industry-specific items included in regulatory areas and the criteria used to rank countries along each item can be found in Gonenç et al. (2001), Boiled and Nicoletti (2001a, 2001b, 2001c), Gonenç and Nicoletti (2001) and Findlay and Warren (2000). 
Table A. 5 Definitions of regulatory areas by industry

\begin{tabular}{|c|c|c|c|}
\hline Industry & Manufacturing $^{1}$ & \multicolumn{2}{|c|}{ Non-manufacturing $^{2}$} \\
\hline \multirow[b]{2}{*}{ Regulatory area } & \multirow{4}{*}{ Administrative burdens $^{3}$} & Fully-competitive & With natural monopoly elements \\
\hline & & & \\
\hline \multirow[t]{2}{*}{ Barriers to entry } & & Administrative burdens (Road, Retail, Hotels ${ }^{3}$ ) & $\begin{array}{l}\text { Legal limitations on } \mathrm{n} \text {. of competitors in potentially } \\
\text { competitive markets (Utilities, Air, Rail, Post. TIc) }\end{array}$ \\
\hline & & $\begin{array}{l}\text { Price floors (Road) } \\
\text { Licensing and other entry restrictions (Road, Retail, } \\
\text { Water, Fin., Prof.) } \\
\text { Involvement of prof. associations (Road, Water) }\end{array}$ & Entrenchment of incumbent (Air) \\
\hline Public ownership & & & $\begin{array}{l}\text { Government shareholdings in incumbent (Air, Tlc, Rail) } \\
\text { Share of public enterprises in market (Utilities, Post) }\end{array}$ \\
\hline Market structure & & & $\begin{array}{l}\text { Market share of new entrants (TIc) } \\
\text { N. of competitors (Tlc, Air) } \\
\text { Concentration index (Air) } \\
\text { Share of incumbent (Utilities, Post, Rail) }\end{array}$ \\
\hline Vertical integration & & & $\begin{array}{l}\text { Degree of unbundling of network from upstream or } \\
\text { downstream potentially competitive markets (Utilities, Tlc, } \\
\text { Post, Rail) }\end{array}$ \\
\hline Price controls & & Administered prices (Retail, Fin., Prof.) & $\begin{array}{l}\text { Administered prices (TIc, Air, Post) } \\
\text { Type of price regulation - access to network and retail (TIc, } \\
\text { Rail, Utilities) }\end{array}$ \\
\hline \multirow[t]{2}{*}{ Constraints on business operation } & & Restrictions on activities (Road, Prof., Fin. Water) & \\
\hline & & Restrictions on use of inputs (Road, Retail) & \\
\hline \multirow[t]{2}{*}{ Trade and FDI restrictions } & Tariff and non-tariff barriers & $\begin{array}{l}\text { Discrimination of foreign firms (Road, Water, Fin., } \\
\text { Prof.) }\end{array}$ & FDI restrictions (Air) \\
\hline & & FDI restrictions (Water, Fin., Prof.) & \\
\hline
\end{tabular}

1. 17 ISIC Rev. 3 industries

2. Road $=$ Road Freight Retail $=$ Retail Distribution; Hotels $=$ Hotels and Restaurants; Water $=$ Maritime Transport; Fin. $=$ Financial Institutions; Prof. $=$ Professional Business Services; Air = Air Transport Carriers; Rail = Railways $;$ Utilities = Electricity, Gas Manufacture and Distribution, Water Works and Supply; Post = Post; Tlc = Telecommunications .

3. Economy-wide administrative burdens

72. Aggregating individual regulations into industry-level regulatory indicators involved three main steps:

- Within each industry, regulatory items included into a single regulatory area were aggregated. For example, an indicator of barriers to entry was generated for the road freight industry by aggregating the sub-indicators concerning industry-specific administrative burdens, price floors, licensing requirements and involvement of professional associations (see Table A.5). At this step, the aggregation procedure differed across industries depending on the number of items available for describing regulation in the industry. Weighted averages were made in industries where regulatory information was abundant (e.g. road freight, retail distribution, air transport, water transport, banking, professional services). In other industries, either aggregation was not needed, because the relevant regulatory areas were described by a single item (e.g. monopoly, duopoly or free entry in mobile telephony), or a simple average was made (e.g. existence of third party access, existence of a wholesale pool and thresholds for consumer choice in electricity generation).

- Indicators for each regulatory area were aggregated within an industry (across industry segments) or industry aggregate (across lower digit industries). For instance, indicators of barriers to entry in the electricity, gas and water industries were aggregated to obtain an indicator of barriers to entry for the electricity, gas and water sector. Aggregation across vertical industry segments (e.g. gas production, transmission and distribution) was made by simple average. Aggregation across horizontal industry segments (e.g. mobile and fixed telephony) was made by weighted average, with weights given by the share of each industry segment in total sales. Aggregation across higher digit industries (e.g. electricity, gas and water) was also made by weighted average, with weights given by average OECD employment shares (since disaggregated data for sales or value added are often lacking). 
When regulatory indicators were missing for some of the higher digit industries included in an industry aggregate (e.g. Wholesale Trade in the Wholesale and Retail Trade aggregate, or Insurance in the Financial Intermediation aggregate) regulation in the industry aggregate was proxied by the weighted average of the available industry-level indicators in that aggregate (Table A.4).

- Finally, summary indicators of industry-level regulation (including several regulatory areas) were computed aggregating the indicators for each regulatory area by means of weighted or simple averages, depending on the amount of regulatory information originally available. For example, the summary indicator for road freight is the weighted average of the indicators of barriers to entry, constraints on business operation and trade and FDI restrictions.

73. The computation of trade barriers in manufacturing industries deserves a special mention because we directly used data on tariff rates and frequency of non-tariff barriers rather than qualitative information on regulations. Original data are at the 6-digit level of the Harmonised System (HS) classification and include the number of tariff lines for each 6-digit industry (usually one). Tariffs are defined as the $a d$ Valero tariff rates applied to the most favoured nation. Conversely, the indicator of non-tariff barriers is a frequency ratio: it corresponds to the proportion of tariff lines to which non-tariff barriers apply. Indicators of tariffs and non-tariff barriers for 1988, 1993 and 1996 have been aggregated into indicators for 2-digit ISIC Rev. 3 industries using import-weights corresponding to 1998 trade flows across OECD countries as obtained from OECD Foreign Trade Statistics. To avoid endogeneity problems, import-weighted trade barrier indicators use the sum of all imports of OECD countries instead of national imports as weights. More specifically, the aggregation procedure that is used for country $i$ and an ISIC aggregate $I$ of 6-digit HS sectors can be formalised as follows:

$$
T_{I, i}=\frac{\sum_{x \in I} T_{x i} i m p_{x}}{\sum_{y \in I} i m p_{y}}
$$

where $\mathrm{T}$ stands for the trade barrier indicator and imp for average OECD-wide imports.

74. A variant of this aggregation formula was used for EU countries, where import-weighted trade barriers are equal, reflecting common trade policies across Member states. The information arising from cross-country import differentials (net of intra-EU imports) was exploited to generate sample variation in trade barriers within the EU, under the assumption that identical tariff or non-tariff measures have a different economic impact (e.g. in terms of distortions) depending on the relative importance of sectors. The following aggregation scheme was applied:

$$
T_{I, j}=\sum_{x \in I} \frac{\frac{I M P_{x j}}{\sum_{k \in E U} I M P_{x k}}}{\sum_{z \in I} \frac{I M P_{z j}}{\sum_{k \in E U} I M P_{z k}}} T_{x j} \frac{i m p_{x}}{\sum_{y \in I} i m p_{y}}
$$

where IMP stands for actual (net of intra-EU) imports of the country $j$. Therefore, normal weights for 6digit industries were increased or decreased of a percentage that reflects the relative importance of that sector for country $j$ with respect to the EU average. 
Using the two digit indicators of tariff and non-tariff barriers, overall measures for manufacturing were obtained using two-digit production weights for 1988.

75. The main sources for the industry-level indicators were: ${ }^{56}$

- The OECD: Regulatory Reform, Privatisation and Competition Policy (1992); The OECD International Regulation Database; OECD Roundtables on competition and regulation, various issues; OECD Reviews of Regulatory Reform, various issues; OECD Economic Studies, n.32 (2001) (and background OECD Economics Department Working Papers n. 251, 237, 238, 254, 255); OECD Report on Regulatory Reform (1997).

- UNCTAD: Trade Analysis and Information System (TRAINS), CD ROM, Winter 1998/1999 (version 6.0).

- The European Conference of Ministers of Transportation: Rail Restructuring in Europe (1998); Regulatory Reforms in the Transport Sector (1987); Competition Policy and Deregulation of Road Transport (1990); Railway Reform (2001).

- The World Bank: Industry Structure and Regulation in Infrastructure: a Cross-Country Survey (1996).

- The European Commission: Liberalisation of Network Industries (1999) (and background documents); Green Paper on Postal Services (1993)

- Center for the Study of Regulated Industries/Privatisation International: I. Lexington (ed.), Utility Regulation (1997).

- Australian Productivity Commission: G. McGuire, M. School and Smith, "Destructiveness of international trade in maritime services", Productivity Commission Staff Research Paper (2000); K. Kalijaran, "Restrictions on trade in business services", Productivity Commission Staff Research Paper (2000); D. Nguyen-Hong, "Restrictions on trade in professional services", Productivity Commission Staff Research Paper (2000); Trade \& Assistance Review 1998-99 (1999).

\subsection{Regulatory reform}

76. Using the above sources, it was possible to collect information on historical developments in regulation over the 1975-1998 period for a subset of the industries covered by the industry-level indicators. These data covered regulatory and market developments in seven energy and service industries: gas, electricity, post, telecommunications (mobile and fixed services), passenger air transport, railways (passenger and freight services) and road freight. As illustrated in Table A.4, the coverage of regulatory areas was more limited than for the 1998 indicators, as were also the items included in each area. Aggregate time-series indicators of regulatory reform (in the different regulatory areas and overall) for the non-manufacturing sector were constructed by taking a simple average of the summary indicators for the seven industries.

56 Other secondary sources include the International Energy Agency, the Universal Postal Union and the National Economic Research Associates. 
77. Similarly, the historical information about tariff and non-tariff barriers to trade was used to construct an indicator of trade liberalisation in the manufacturing sector. To this end, the productionweighted tariff and non-tariff barriers for the manufacturing aggregate in 1988, 1993 and 1996 (see above) were interpolated and their end-of-period value was extrapolated to 1998.

\subsection{Privatisation}

78. The main sources for the time-series indicator of public ownership were the following:

- The Economic Freedom of the World (EFW) index of Government Enterprises (II.a) [Economic Freedom of the World, Annual Report, 1997, J. Gwartney and R. Lawson, Fraser Institute, Ottawa] ${ }^{57}$. This index (available at 5 years intervals since 1975) ranks countries in 6 classes (0-10) according to the following criteria concerning state owned enterprises (SOEs):

\begin{tabular}{|l|l|}
\hline $\begin{array}{l}\text { SOEs value added }>=30 \% \text { of (non agric. business) GDP, all sectors } \\
\text { dominated by SOEs }\end{array}$ & 0 \\
\hline $\begin{array}{l}20 \%=<\text { SOEs value added < 30\% of (non agric. business) GDP, many sectors } \\
\text { dominated by SOEs, including manuf and retail }\end{array}$ & 2 \\
\hline $\begin{array}{l}10 \%=<\text { SOEs value added < 20\% of (non agric. business) GDP, many sectors } \\
\text { dominated by SOEs, including manufacturing }\end{array}$ & 4 \\
\hline $\begin{array}{l}\text { SOEs value added < 10\% of (non agric. business) GDP, SOEs in network } \\
\text { industries and energy, many SOEs }\end{array}$ & 6 \\
\hline $\begin{array}{l}\text { SOEs value added < 10\% of (non agric. business) GDP, SOEs in network } \\
\text { industries, but few SOEs }\end{array}$ & 8 \\
\hline SOEs value added < $1 \%$ of (non agric. business) GDP & 1 \\
\hline
\end{tabular}

- The OECD Privatisation Database [partially published in Financial Market Trends, various issues, OECD] reports number of sales and sale receipts (including both direct and indirect privatisation by state holding companies for some countries) by year. Generally the data start when full-blown privatisation programmes are first implemented (e.g. early 90s for most countries, earlier for a few of them). Privatisation is defined as full or partial transfers of ownership.

- The EBRD privatisation database [as reported in the EBRD Transition Report] reports share in GDP of privatisation receipts by year as well as share of private sector in economic activity

- The database on SOEs by the Centre Européen des Entreprises à Participation Publique [Annales CEEP, Bruxelles, various issues] reports the shares in (non agricultural business) GDP of SOEs' value added, employment and investment for the EU countries. The index is available at 3 years intervals since 1982 .

57 A new index has been made available in 2001 [Economic Freedom of the World, Annual Report, 2001, J. Gwartney and R. Lawson, Fraser Institute, Ottawa] based on the share of SOEs investment instead of SOEs value added, but we chose to rely on the old index to ensure consistency with earlier work and the supplementary sources used to construct the indicators (see below). 
79. The methodology for constructing the public ownership index involved several steps. First, the value of the EFW index in 1975 (which is available for all OECD countries) is taken as a starting point for calculations. Second, this starting value $\left(\mathrm{PO}_{75}\right)$ is checked and adjusted (if needed) using more detailed information coming from the EBRD and CEEP reports and OECD country desks; such adjustments have concerned: Belgium, Denmark, Germany, Finland, France, the Netherlands, Korea, Turkey and the United States. The data on the share of privatisation receipts in GDP $\left(\mathrm{S}_{\mathrm{t}}\right)$ is used to create a new time-series of the SOEs role in the economy $\left(\mathrm{PO}_{\mathrm{t}}\right)$ according to the following rule:

$$
\mathrm{PO}_{\mathrm{t}}=\mathrm{PO}_{\mathrm{t}-1}+0.2 * \mathrm{~S}_{\mathrm{t}}
$$

Thus the EFW index declines by 2 points when privatisation receipts account for $10 \%$ of GDP. This formula is consistent with EFWs original criterion for ranking countries, provided the share of privatisation receipts in GDP is approximately equal to the share in GDP of the output of privatised firms.

Finally, PO was rescaled from least to most restrictive of private governance to be consistent with the other indicators of regulation and the indicator of privatisation was defined as the first difference of PO.

\subsection{Use of regulatory indicators in regressions}

80. While the economy-wide and industry-level indicators of regulation described above were used in the descriptive analysis of Section 3, the following assumptions and simplifications were made when these indicators were used in the econometric analysis of Section 4:

- To sharpen the interpretation of the empirical results, the focus was restricted to public ownership/privatisation and barriers to entry/entry liberalisation.

- Barriers to entry were netted out of the market structure element to avoid potential endogeneity problems between regulation and MFP.

- Barriers to entry in the Hotels and Restaurants industry were proxied by economy-wide administrative burdens.

- Barriers to entry in manufacturing industries were assumed to consist of a weighted average between industry-specific tariff and non-tariff barriers to trade and economy-wide administrative burdens.

All indicators were rescaled from 0 to 1 (from least to most restrictive) prior to estimation

\section{The construction of MFP measures and sensitivity of results}

\subsection{Variables used in the baseline MFP regressions}

The main data-set is the OECD STAN (2001 edition) database. More details on the construction of the baseline variables used in the productivity analysis is provided in Scarpetta and Tressel (2002).

The OECD databases include information on the capital stock. However, in some instances, available series are incomplete. In such cases, gross fixed capital stock series were estimated using the perpetual inventory method. 
The labour input is based on information on employment from the OECD STAN database. These data were complemented with data on hours worked at the sectoral level from the ILO (LABORSTA) for the following countries: Australia, Austria, Finland, France, Norway, Portugal, Spain, Greece, Italy, Japan Netherlands and New Zealand. For the United States, data are from the BLS, while those for Canada are from the Canadian National Statistics Office. For the remaining countries (e.g. Belgium, Denmark and Germany), data are from CRONOS. In order to minimise cross-country differences in total hours worked, industry data were re-scaled on the basis of available nation-wide OECD data on hours worked.

The construction of the human capital variable required information on relative wages by skills. These data have a country and an industry dimension, but generally refer to the early 1990s. The primary source of these data is the OECD DEELSA database on employment, which, in turn, is based on the European Structure of Earnings Survey (Eurostat) for EU countries; OECD calculations on the microdata file of the outgoing rotation group of the Current Population Survey for the United States; and Structure of Earnings Surveys or Labour Force Surveys for the other countries. Data on wages for Portugal, Netherlands, Finland, Norway, Germany, Australia and Japan were proxied with those in neighbouring countries.

The construction of the human capital variable also requires data on the skill composition of employment. These data have a country, industry and time dimension. They are form $i$ ) the DEELSA data described above; ii) the skill data in OECD STI Working Paper No. 1998/4; and iii) ILO data on aggregate employment for the four skill categories.

Finally, the calculations of MFP levels requires the use of comparative product price levels across countries in order to convert the value of production to common units, while taking into account differences in the purchasing power of each country's currency. We used a set industry-specific PPPs. The starting point of these calculations was the PPPs for detailed expenditure headings from the United Nations International Comparisons Project (ICP). These detailed PPPs were mapped into the STAN classification of industries by assigning each basic expenditure heading bought by consumers, firms or the government to its industry of origin. When the basic heading includes products produced in more than one industry, the same price was assigned to all the industries concerned. Within each industry, proxies of the product prices were obtained aggregating the basic headings with the corresponding expenditure shares. However, there are a number of problems in using expenditure PPPs for industry productivity comparison. In particular, the presence of distribution and transportation margins, indirect taxes and the inclusion/exclusion of the prices of imported/exported goods all tend to create a gap between expenditure prices and production prices. While available data did not allow accounting for distribution and transportation margins, corrections were made for both indirect taxes and international trade.

On the basis of the methodology described in the main text, we calculated MFP levels as well as growth rates for each unit of observations (country-industry pair) in our sample. Table A.6 presents the countries with the highest estimated level of MFP in each industry at the beginning and at the end of the sample period. 
Table A.6 Technology leaders on the basis of relative MFP levels, 1984, 1997

\begin{tabular}{|c|c|c|c|}
\hline & \multirow[b]{2}{*}{ rank } & \multicolumn{2}{|c|}{ Country ranking } \\
\hline & & 1984 & 1997 \\
\hline \multirow{3}{*}{ Food products, beverages and tobacco } & $1^{\text {st }}$ & USA & CAN \\
\hline & $2^{\mathrm{d}}$ & JPN & USA \\
\hline & $3^{d}$ & CAN & JPN \\
\hline \multirow[t]{3}{*}{ Textiles, textile products, leather and footwear } & $1^{\text {st }}$ & FRA & CAN \\
\hline & $2^{\mathrm{d}}$ & CAN & FRA \\
\hline & $3^{\mathrm{d}}$ & AUT & ITA \\
\hline \multirow[t]{3}{*}{ Wood and products of wood and cork } & $1^{\text {st }}$ & CAN & USA \\
\hline & $2^{d}$ & USA & FIN \\
\hline & $3^{d}$ & GRC & NOR \\
\hline \multirow[t]{3}{*}{ Pulp paper, paper products, printing and publishing } & $\overline{1^{\text {st }}}$ & CAN & FRA \\
\hline & $2^{d}$ & FRA & CAN \\
\hline & $3^{d}$ & USA & ITA \\
\hline \multirow[t]{3}{*}{ Coke, refined petroleum products and nuclear fuel } & $\overline{1^{s t}}$ & ITA & ITA \\
\hline & $2^{d}$ & FRA & FIN \\
\hline & $3^{d}$ & USA & USA \\
\hline \multirow[t]{3}{*}{ Chemicals excluding pharmaceuticals } & $\overline{1^{\text {st }}}$ & FIN & FIN \\
\hline & $2^{\mathrm{d}}$ & BEL & FRA \\
\hline & $3^{\mathrm{d}}$ & GER & CAN \\
\hline \multirow[t]{3}{*}{ Pharmaceuticals } & $\overline{1^{\text {st }}}$ & JPN & CAN \\
\hline & $2^{d}$ & USA & NOR \\
\hline & $3^{d}$ & NOR & GER \\
\hline \multirow[t]{3}{*}{ Rubber and plastics products } & $\overline{1^{\text {st }}}$ & AUT & ITA \\
\hline & $2^{d}$ & DNK & FIN \\
\hline & $3^{d}$ & ESP & USA \\
\hline Other non-metallic mineral products & $1^{\text {st }}$ & CAN & CAN \\
\hline & $2^{d}$ & AUT & FRA \\
\hline & $3^{d}$ & BEL & USA \\
\hline Basic metals & $1^{\text {st }}$ & NLD & FIN \\
\hline Dasil melars & $2^{\mathrm{d}}$ & DNK & JPN \\
\hline & $3^{d}$ & JPN & NOR \\
\hline Fabricated metal products except machinery and equipment & $\overline{1^{\text {st }}}$ & CAN & USA \\
\hline & $2^{d}$ & BEL & FIN \\
\hline & $3^{\mathrm{d}}$ & GER & JPN \\
\hline Machinery and equipment n.e.c. & $1^{\text {st }}$ & CAN & FRA \\
\hline & $2^{d}$ & GER & FIN \\
\hline & $3^{d}$ & DNK & ITA \\
\hline Electrical and optical equipment & $\overline{1^{\text {st }}}$ & AUS & FIN \\
\hline & $2^{d}$ & DNK & JPN \\
\hline & $3^{\mathrm{d}}$ & JPN & FRA \\
\hline Motor vehicles trailers and semi-trailers & $\overline{1^{\text {st }}}$ & USA & USA \\
\hline & $2^{\mathrm{d}}$ & GRC & FRA \\
\hline & $3^{d}$ & CAN & FIN \\
\hline Building and repairing of ships and boats & $\overline{1^{\text {st }}}$ & FRA & CAN \\
\hline & $2^{d}$ & USA & GER \\
\hline & $3^{d}$ & ITA & NOR \\
\hline Aircraft and spacecraft & $1^{\text {st }}$ & FRA & CAN \\
\hline & $2^{\mathrm{d}}$ & CAN & GER \\
\hline & $3^{d}$ & GER & NLD \\
\hline Railroad equipment and transport equipment n.e.c. & $1^{\text {st }}$ & ITA & CAN \\
\hline & $2^{d}$ & CAN & FIN \\
\hline & $3^{d}$ & FRA & GBR \\
\hline Manufacturing n.e.c; recycling & $7^{\text {st }}$ & CAN & FRA \\
\hline & $2^{d}$ & USA & USA \\
\hline & $3^{d}$ & FIN & FIN \\
\hline Wholesale and retail trade; repairs & $1^{\text {st }}$ & ITA & ITA \\
\hline & $2^{d}$ & BEL & CAN \\
\hline & $3^{d}$ & USA & FRA \\
\hline Hotels and restaurants & $1^{\text {st }}$ & BEL & USA \\
\hline & $2^{d}$ & FRA & ITA \\
\hline & $3^{\mathrm{d}}$ & NOR & FRA \\
\hline Transport and storage & $\overline{1^{\text {st }}}$ & BEL & FRA \\
\hline & $2^{d}$ & ITA & USA \\
\hline & $3^{d}$ & FRA & CAN \\
\hline Post and telecommunications & $\overline{1^{\text {st }}}$ & USA & FRA \\
\hline & $2^{d}$ & CAN & USA \\
\hline & $3^{d}$ & FRA & CAN \\
\hline Financial intermediation & $1^{\text {st }}$ & NOR & ITA \\
\hline & $2^{d}$ & CAN & FRA \\
\hline & $3^{d}$ & ITA & FIN \\
\hline Real estate renting and business activities & $1^{\text {st }}$ & AUS & USA \\
\hline & $2^{d}$ & USA & FRA \\
\hline & $3^{d}$ & SWE & NLD \\
\hline
\end{tabular}

\subsection{Sensitivity analysis}

81. In our empirical analysis, we checked for the robustness of results in different ways. First to check whether the empirical links between productivity and regulations are robust, we experimented with different indicators of regulation, entry liberalisation and privatisation. Moreover, as discussed in the main 
text, we have identified, by means of a by-now standard statistical procedure, a set of outlier observations that significantly affect the fit of the equation or the estimated coefficients and we removed them from the sample. To test the importance of their exclusion from the sample we replicated our preferred productivity equations on the full sample (Table A.7). The results are broadly consistent with those in the equations presented in the main text, with a few exceptions. In particular, the estimated coefficients of the MFP growth of the leader countries for manufacturing has is negative and marginally significant (at the 10 per cent level) in the equations of Table A.7, while it was not statistically significant in the equations of the main text. Moreover, the inclusion of the outliers in the sample led to an increase in the estimated standard error of the human capital variable whose coefficient was no longer statistically significant in two of the three specifications.

Table A.7. Sensitivity of MFP regressions: preferred specifications without control for outliers

Dependent variable: $\triangle \mathrm{MFP}_{\mathrm{ijt}}$

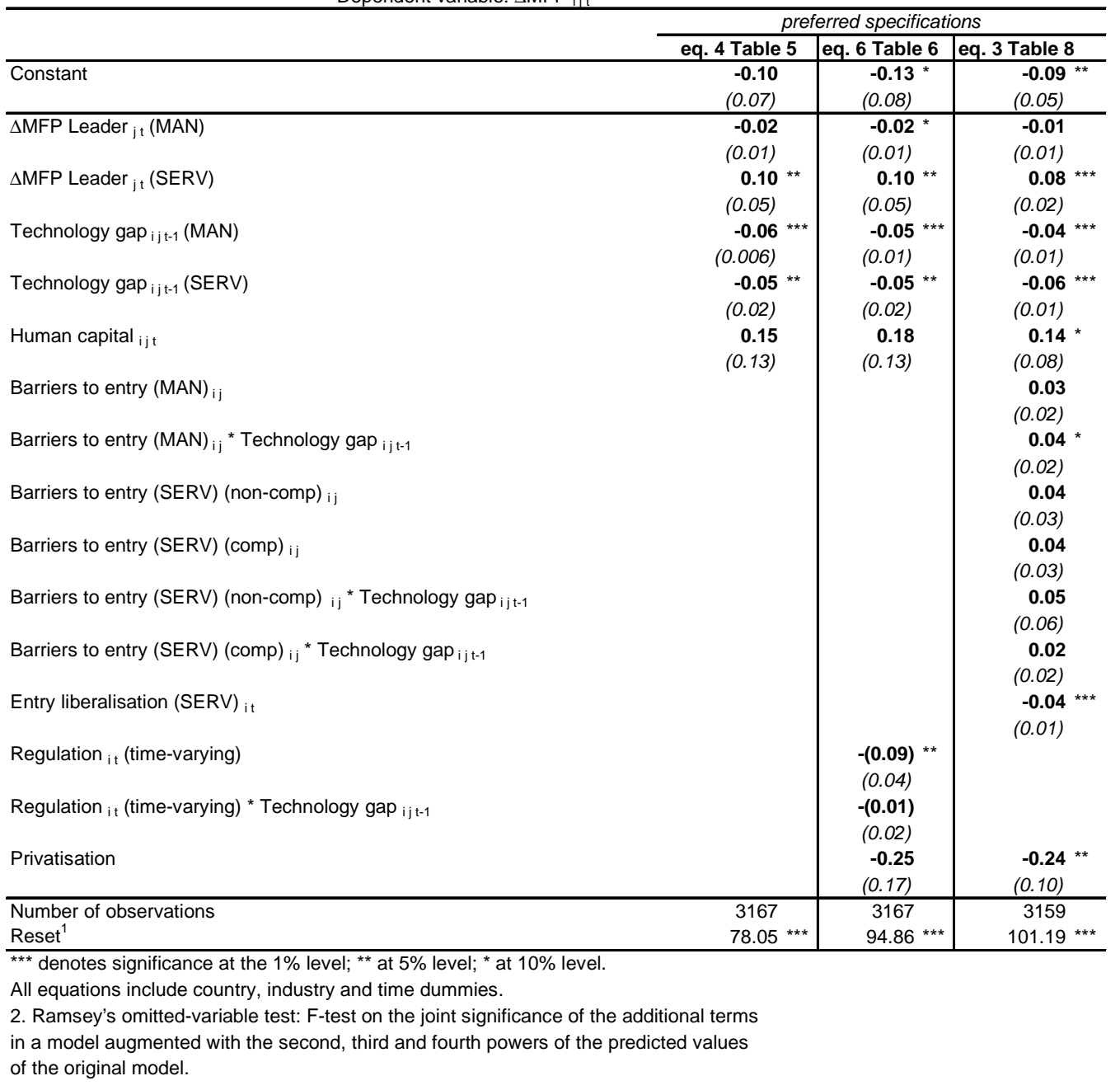

82. A third step in the sensitivity analysis was to check for possible estimation problems related to the presence of specific industries in given countries that, because of different technological features or simply measurement errors, influence significantly the overall results. To address this issue, we ran rolling regressions in which one unit of observation (a country-industry pair) is excluded at a time, and checked how the value and statistical significance of the coefficients of the regulatory and privatisation variables changed across regressions. Figure A.2 shows how the statistical significance of the coefficients of the two preferred specifications (eq. 6 in Table 6 and eq. 3 in Table 8) varies as the sample changes. The t-statistics 
remain largely unaltered corroborating the results discussed in the previous section. There are, however, a few observations that significantly affect the results. In particular, the significance of regulatory coefficients is influenced by the presence in the sample of some concentrated industries in manufacturing (e.g. coke and refined petroleum, chemicals, basic metals), as well some service industries (e.g. post and telecommunications, financial intermediation): in both cases productivity may be poorly estimated due to specific market conditions and/or difficulties in measuring output. ${ }^{58}$ Nevertheless, we did not remove these unit of observations from our sample because none of them seemed to affect systematically all (or the majority of) the regulatory coefficients and could thus be consider as an overall outlier. ${ }^{59}$

Figure A.2. Sensitivity analysis ${ }^{a}: T$-statistics of estimated coefficients

Panel A: Regulatory and privatisation variables in equation 6 of table 6.
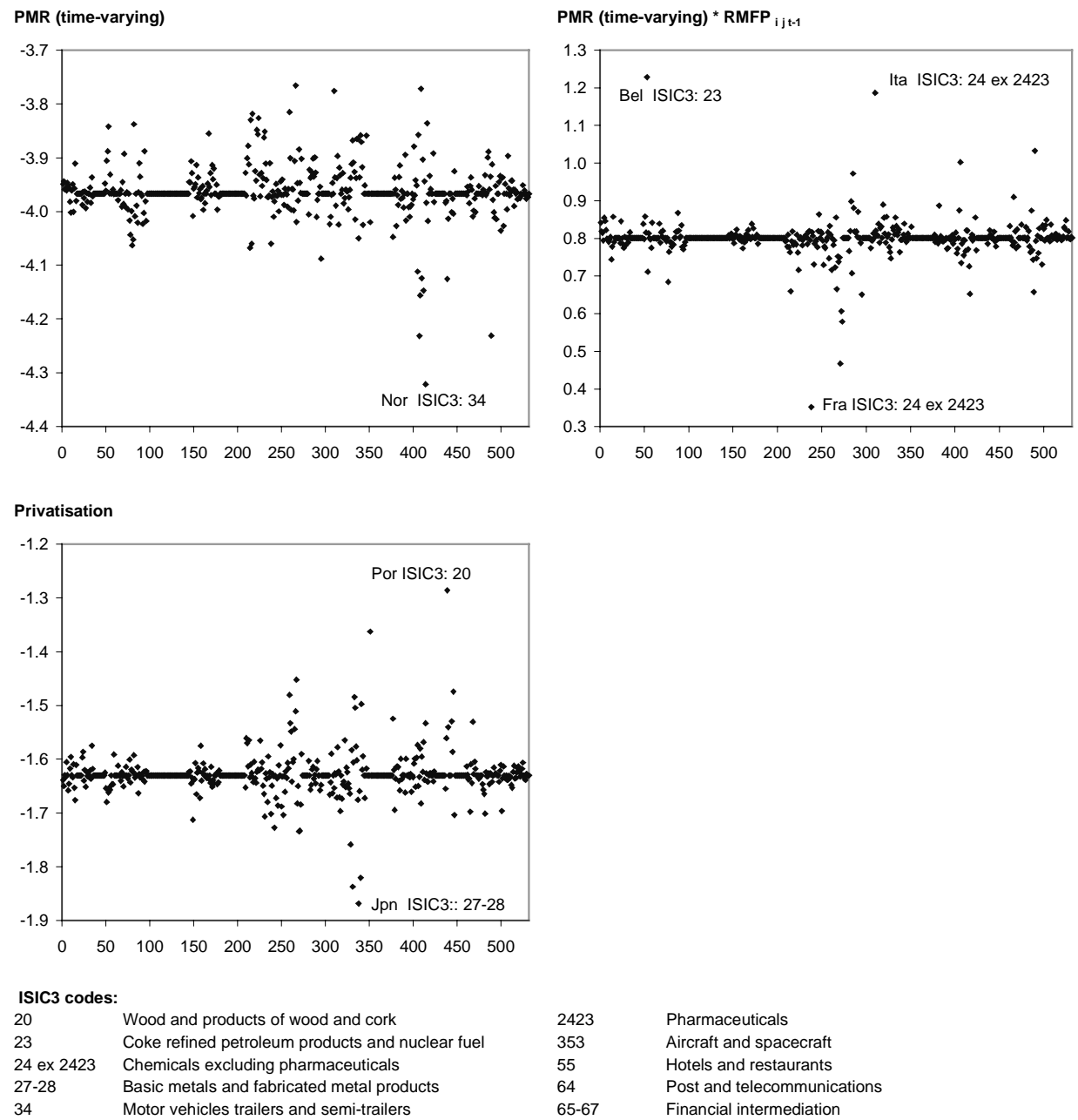

a. Each dot represents the estimated t-statistics in a specification in which one (country-industry) observations is removed for the sample (532 in total).

58 Our productivity model includes industry dummies that capture common (cross-country) industry-specific technology features. However, our industry breakdown is fairly aggregate and possibly not enough to fully characterise common (cross-country) industry types, especially for small countries that tend to be specialised in specific marked niches in many manufacturing and service industries.

Moreover, it should be stressed that there were only two cases in which the removal of these units of observations turned an otherwise statistically significant coefficient (in both cases only at the 10 per cent level) into a statistically not significant one. 
ECO/WKP(2003)1

anel B: Regulatory and privatisation variables in equation 3 of table 8.

PMR (sectoral) (MAN)

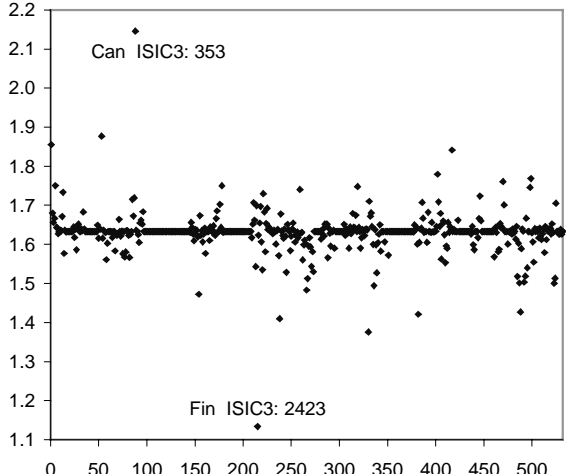

PMR (sectoral) (SERV) (comp)

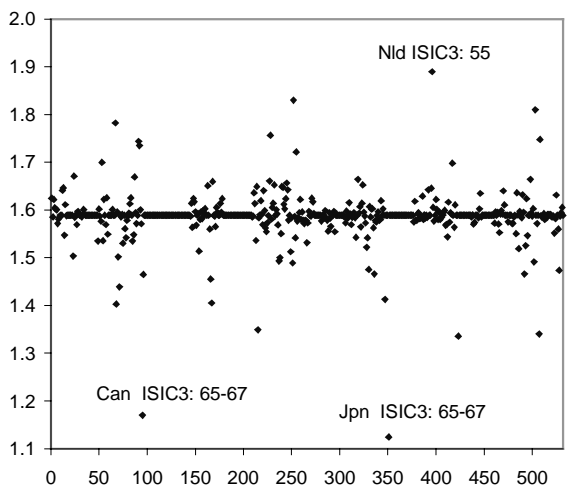

PMR (sectoral) RMFP $_{\mathrm{ij} \text { t-1 }}$ (SERV) (non-comp)

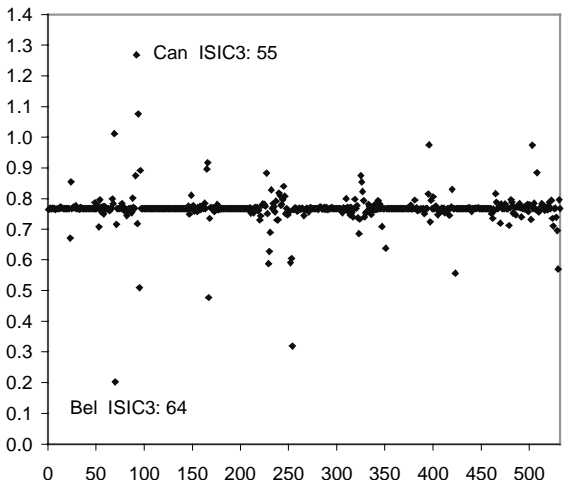

PMR (aggregate, time varying)

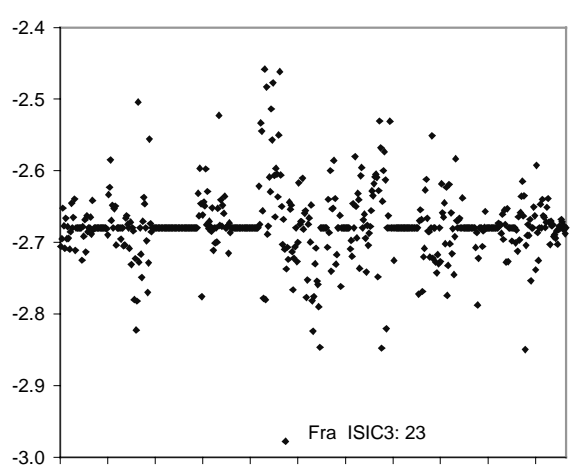

PMR (sectoral) * RMFP

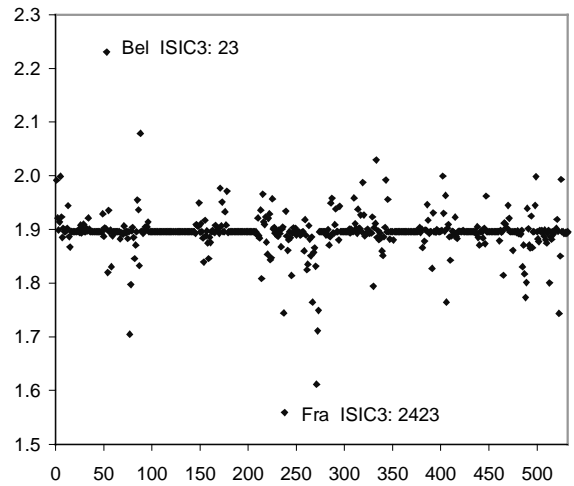

PMR (sectoral) (SERV) (non-comp)

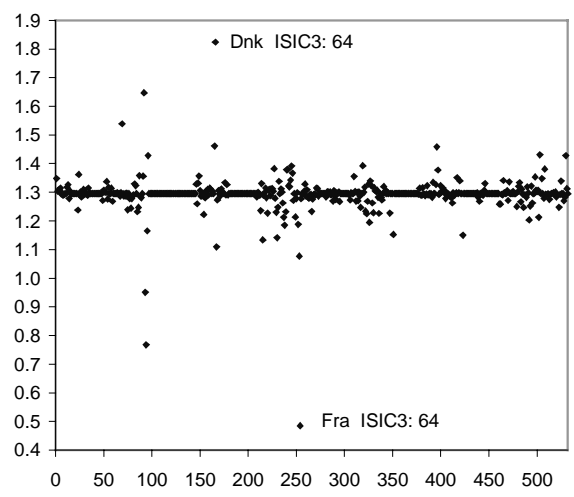

PMR (sectoral) * RMFP $_{i \mathrm{i} t-1}$ (SERV) (comp)

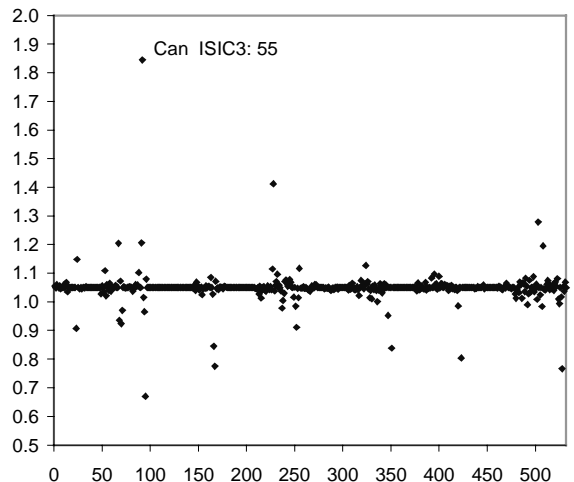

Privatisation

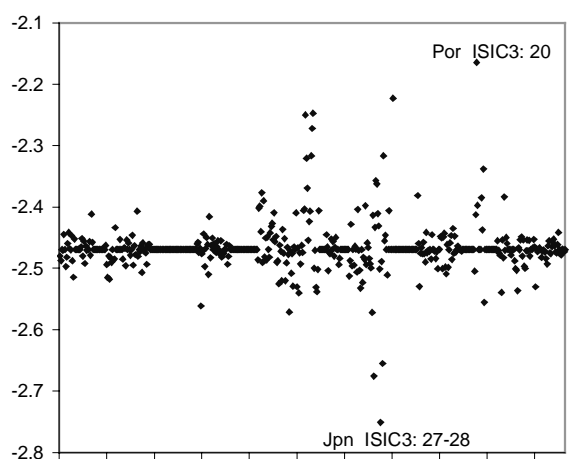




\section{RECENT ECONOMICS DEPARTMENT \\ WORKING PAPERS}

The full series of Economics Department Working Papers can be consulted at www.oecd.org/eco/Working Papers/

346. Public Expenditure Management in Poland

(December 2002) Andrew Burns and Kwang-Yeol Yoo

345. Enchancing the Effectivesness of Public Expenditure in Sweden

(December 2002) Deborah Roseveare

344. The Decline in Private Saving Rates in the 1990s in OECD Countries: How Much Can Be Explained by NonWealth Determinants

(November 2002) Alain de Serres and Florian Pelgrin

343. Enhancing the Effectiveness of Public Expenditure in Norway

(October 2002) Isabelle Joumard and Wim Suyker

342. Productivity and Convergence in a Panel of OECD Countries: Do Regulations and Institutions Matter? (September 2002) Stefano Scarpetta and Thierry Tressel

341. Managing Public Expenditure: The UK Approach (August 2002) Paul van den Noord

340. The Brazilian Pension System: Recent Reforms and Challenges Ahead (August 2002) Marcos Bonturi

339. Challenges in the Mexican Financial Sector (August 2002) Marcos Bonturi

338. Coping with Population Ageing in Hungary (August 2002) Andrew Burns and Jaromir Cekota

337. Next Steps for Public Spending in New Zealand: The Pursuit of Effectiveness (July 2002) Dave Rae

336. Strengthening the Management of Public Spending in Hungary (July 2002) Jaromir Cekota, Rauf Gonenc and Kwang-Yeol Yoo

335. Automatic Stabilisers and Market Flexibility in EMU: Is There a Trade-Off? (July 2002) Marco Buti, Carlos Martinez-Mongay, Khalid Sekkat and Paul van den Noord

334. The Economic Consequences of Terrorism (July 2002) Patrick Lenain, Marcos Bonturi and Vincent Koen

333. Investment in human capital through post-compulsory education and training: Selected efficiency and equity aspects

(July 2002) Sveinbjörn Blöndal, Simon Field and Nathalie Girouard

332. Enhancing the Effectiveness of Public Spending in Switzerland (June 2002) Isabelle Joumard and Claude Giorno

331. Competition and Efficiency in Publicly Funded Services (June 2002) Jens Lundsgaard 
330. Policy Pre-Commitment and Institutional Design: A Synthetic Indicator Applied to Currency Boards (May 2002) Marie-Thérèse Camilleri Gilson

329. The Role of Policy and Institutions for Productivity and Firm Dynamics: Evidence from Micro and Industry Data (April 2002) Stefano Scarpetta, Philip Hemmings, Thierry Tressel and Jaejoon Woo

328. Improving the Efficiency and Sustainability of Public Expenditure in the Czech Republic (April 2002) Andrew Burns and Kwang-Yeol Yoo

327. Increases in Business Investment Rates in OECD Countries in the 1990s: How much can be explained by fundamentals? (April 2002) Florian Pelgrin, Sebastian Schich and Alain de Serres

326. Sectoral Shifts in Europe and the United States: How They Affect Aggregate Labour Shares and the Properties of Wage Equations

(April 2002) Alain de Serres, Stefano Scarpetta and Christine de la Maisonneuve

325. Coping with Population Ageing in the Netherlands (March 2002) David Carey

324. Public Spending in Italy: Policies to Enhance its Effectiveness (March 2002) Alexandra Bibbee and Alessandro Goglio

323. Overheating in Small Euro Area Economies : Should Fiscal Policy React? (March 2002) Peter Hoeller, Claude Giorno and Christine de la Maisonneuve

322. Encouraging Environmentally Sustainable Growth in Austria (February 2002) Jens Høj and Andreas Wörgötter

321. Health Care Reform in Japan (February 2002) Yutaka Imai

320. Enhancing Expenditure Control with a Decentralised Public Sector in Denmark (February 2002) Steen Daugaard

319. Options for Reforming the Finnish Tax System (February 2002) Isabelle Joumard and Wim Suyker

318. Product Market Regulation and Wage Premia in Europe and North America: An Empirical Investigation (January 2002) Sébastien Jean and Giuseppe Nicoletti

317. Competition, Innovation and Productivity Growth: A Review of Theory and Evidence (January 2002) Sanghoon Ahn

316. Labour Market Institutions, Product Market Regulation, and Innovation : Cross Country Evidence (January 2002) Andrea Bassanini and Ekkehard Ernst

315. Ongoing Changes in the Business Cycle - Evidence and Causes (January 2002) Thomas Dalsgaard, Jorgen Elmeskov and Cyn-Young Park

314. Comment encourager une croissance ecologiquement durable en France? (December 2001) Ann Vourc'h et Patrick Lenain 